

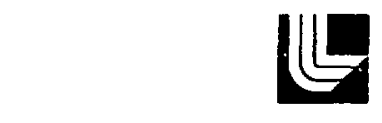

LAWRENCE IJVERMORE LABORATORY

University of Cahtoinia Livermore.California 94550

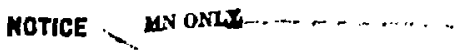

PARTIOHS OF THS REPOAT ARE ILLGTELEn'

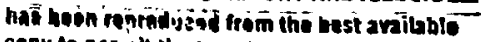
capy to perrith the brescest possibte araik ebitity.

UCRL-\$2469

\title{
HYDROGEOCHEMICAL AND STREAM SEDIMENT RECONNAISSANCE BASIC DATA KEPORT FOR WINNEMUCCA NTMS QUADRANGLE, NEVADA
}

\author{
K. P. Puchlik
}

MS. date: May, 1978

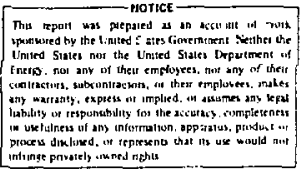




\section{CONTENTS}

Abstract . . . . . . \& . • . . . . . . . . . . . . 1

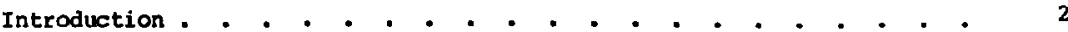

Geology of the Winnemucca NTMS Sheet . . . . . + . . . . . . 3

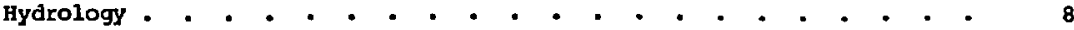

Sample Site Selection and Collection . • . . . . . . . . . . . 9

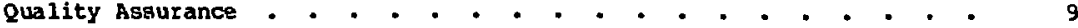

Geochemistry . . . . . . . . . . . . . . . . . . . . 11

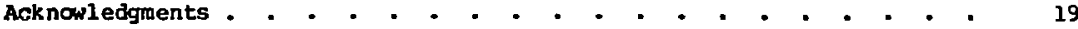

References + . . + . . . . + . . . + . . . . . . . 20

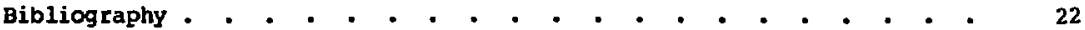

Appendix A Data Organization and Definitions . . . . . . . . . A-1

Appendix B Numerical Results of Reconnaissance Survey . . . . . . B-1

\section{FIGURES}

Figure 1. Areas of responsibility for the NURE Hydrogeochemical

Reconna issance Drogram .

Figure 2. Location of Finnemucca NTMS quadrangle...., 4

Figure 3. Uranium occurrence map . 6

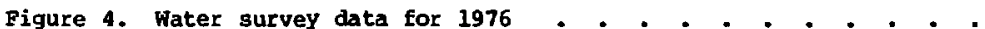

Figure 5. Distribution of samples with uranium concentrations

of more than 5 ppm . . . . . . . . . . . . . . 13

Figure 6. Distribution of samples with uraniun concentratlons of more than $5 \mathrm{ppm}$ and Th/0 less than 2.0. . . . . . 14

Figure A-1 Uranium concentrations in water saimples . . . . . . . A-5

Figure A-2 Uranium concentrations in sediment samples . . . . . . A-5

Figure A-3 Blstogram (a) and cumulative frequency distribution (b) of water samples plotted on overlay 1B . . . . . . . A-6

Figure A-4 Histogram (a) and cumulative frequency distribution (b) of sediment samples plotted on overlay 2B . . . . . . A A

Figure A-5 Histogram (a) and cumulative frequency distribution (b) of sediment samples plotted on overlay 2C . . . . . . A-8 


\section{TABLES}

Table 1. Delayed neutron assay for uranium analyses of DOE inter laboratory compar ison semples . . . . . . . . . 11

Table 2. Water analysis; main Humboldt Ríver . . . . . . . . . 17

Table B-1. Sediment analysis; dry and stream sites. . . . . . . B-2

Table B-2, Water analysis; rivers, streams and lakes . . . . . . B-25

Table B-3. Water analysis; spring and well sites. . . . . . . . B-28

\section{MICROFICHE TABLES (Rear Pocket)}

\section{OVERLAYS (Rear Pocket)}

The overlays in the rear pocket are:

Over lay 1A. Site Locations, Water Samples

Oyer lay 1B. Total Uranium Concentrations, Water Samples

Over lay 2A. Site Locations, Sediment Samples

Overlay 2B. Total Uranium Concentrations, Sediment Samples

overlay 2C. Total Thorium Concentrations, Sediment Samples 


\section{HYDROGEOCHEMICAL AND STREAM SEDIMENT RECONNAISSANCE BASIC DATA REPORT FOR WINNEMUCCA NTMS QUADRANGLE, NEVADA}

\section{ABSTRACT}

This report presents the results of the geochemical reconnaissance sampling in the Winnemucca $1^{\circ} \times 2^{\circ}$ quadrangle of the National Topographic Map Series (NTMS). We collected wet and dry sediment samples throughout the $18,770-\mathrm{km}^{2}$ arid to semi-arid area and water samples at available streams, springs and wells. We present neutron activation analyses of uranium and trace elements and other measurements made in the field and laboratory in tabular hardcopy and microfiche format. The report includes 5 full-size overlays for use with the Winnemucca NTMS 1:250,000 quadrangle. Water sampling sites, water-sample uranium and thorium concentrations, sediment sampling sites, and sediment-sample total uranium and thorium concentrations are shown on the separate overlays. We present general geological and structural descriptions of the area, and describe the 12 known uranium occurrences.

The results indicate that the uranium geochemistry of the area is diverse. High concentrations (greater than $5 \mathrm{ppm}$ ) of uranium in sediments are associated mainly with rhyolitic ash falls and flows and silicic intrusives. In defining areas of interest the ratio of relatively insoluble thorium to uranium was considered. The anomalies as defined are then the sediment samples containing $10 \mathrm{~W} T \mathrm{Th} / \mathrm{U}$ and high uranium concentrations. These areas consist mainly of fluvial-lacustrine units. Most known uranilim occurrences were also identified by this technique. The main dumboldt River shows an irregular increase in uranium concentration downstream which may be related to agricultrual modification of the stream flow. U/Cl ratios were used to evaluate the effects of evaporative concentration. of interest are spring and tributary waters containing high $\mathrm{U} / \mathrm{Cl}$ and high uranium values. These waters mainly drain acid intrusives, silicic volcanic rccks and related sediments. One such areb is the Shoshone and Cortez Mountains. 


\section{INTRODUCTION}

The National Uranium Resource Evaluation (NURE) P:ogram was established to evaluate domestic uranium resources in the continental. U. S. and identify areas favorable for uranium exploration. The Grand Junction office (GJO) of the Department of Energy (DOE) is responsib'e for administering and coordinating NURE program efforts. Lawrence Livermore Laboratory (LLL) is conducting a hydrogeochemical and stream-sediment reconnaissance (HSSR) of 1..8 million $\mathrm{km}^{2}$ in 10 western states. Other DOE laboratories are responsible for similar reconsaissance in the rest of the continental U. S. including Alaska (Fig, 1). The individual laboratories acquire a proper set of field samples in their areas, process and analyze the materials, and conpile the data in report form. The resulting HSSR reports are made available to the public by DOE-GJO through simultaneous release at several locations. The Lawrence Livermore Laboratory relcases its data as basic data reports with an interpretative discussion concerning its significance. The data are reviewed and presented in tabular form with map overlays.

Lawrence Livermore Laboratory subdivides the 10 western states into commonly recognized geologic provinces that at . Eurther subdivided into sample acquisition or project areas. Each is sampled in an appropriately timed reconnaissance phase with professional geological contract teams monitorec by

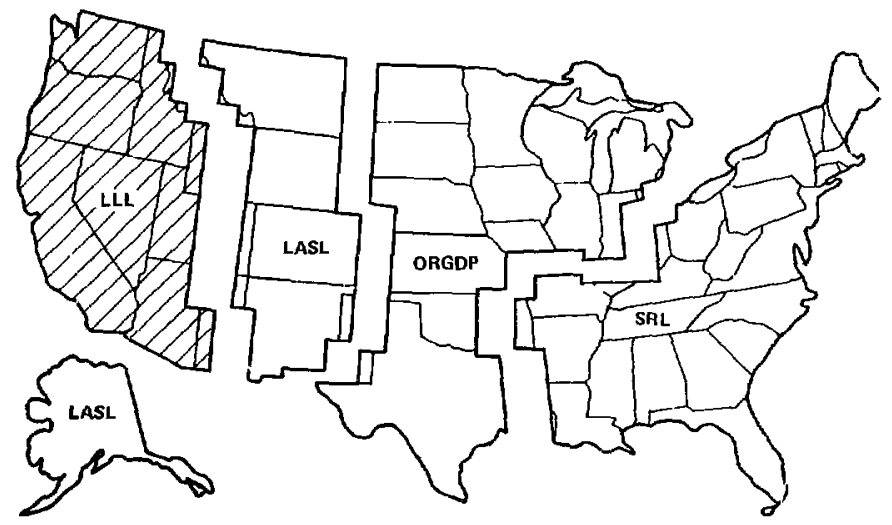

Fig. 1. Areas of responsibility for the NURE Hydrogeoche wlcal. Reconnaissance program. 
the LIL field quality-assurance group. Before starting a major field reconnaissance coverage, LLL conducts one or more "pilot" or orientation studies in the geological province, providing a rational sediment and water sampling frogram sensitive to variable geological and climatic conditions that exist in the area. ${ }^{1}$ In this way the sediment and water samples reflect, as nearly as possible, the metallogenic nature of the region with particular emphasis on uranium mineralization. A description of sample collection and processing methods is available. 2

The samples were analyzed for uranium by delayed neutron counting. Instrumental neutron activation analysis was used to measure trace and major element content of sediment samples. The samples were irradiated at the Livermore pool Type Reactor (LPTR). The neutron activation analysis and dolayed neutron counting are performed using an automated transport and detection system described by Smith. ${ }^{3}$ Data reduction for neutron activation analytical results utilizes the GaMANaL code described by Gunnick and Niday ${ }^{4}$ to interpret the gamina spectra. The NURAB code described by Heft and Martin ${ }^{5}$ and Mckillan and Carver ${ }^{6}$ produces the elemental concentration values.

An automated optical emission spectrometer equipped with an argon plasma source provided trace and major element analyses of water samples. A modified spectrophometric analyzer was used to obtain measurement of chloride and sulphate concentrations of water samples.

\section{GEOLOGY OF THE WINNEMUCCA NTMS SHEET}

The Winnemucc:a NTMS $1^{\circ} \times 2^{\circ}$ sheet chvers an area of approximately $18,770-\mathrm{km}^{2}(7,250$ square miles $)$ in north-central Nevada that is within the Basin and Range physiographic province (Fig. 2). Parts of Humboldt, Lander, Pershing, Eureka, and Elko counties lie within the quadrangle. These areas have been geclogically mapped and the results published as Nevada Bureau of Mines county reports by Willden, ${ }^{7}$ Stewart et al. ${ }^{\text {B }}$ Johnston, 9 Roberts et $a 1.1^{10}$ and Grancjer et al. ${ }^{11}$

The region consists of northward-trending, block-faulted ranges separated by alluvial valleys and is part of the larger Humbo:dt River drainage basin. The Humboldt River flows from east to west through much of the area at right angles to the north-iouth trend of the topography. 


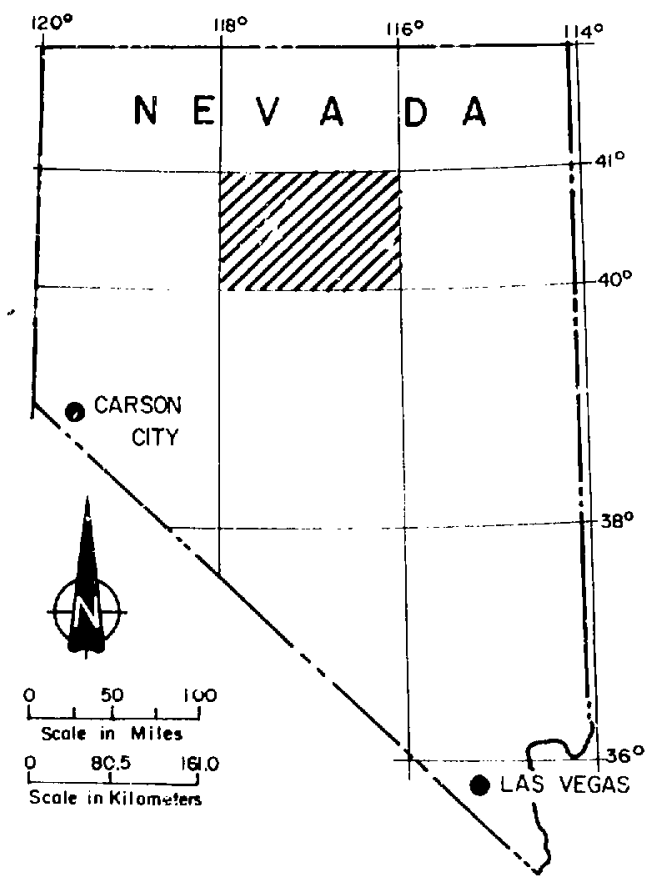

Fig. 2. Location of Wirnemucca NTMS Quadrangle.

The area is a geologically and structurally complex transition zone between miogeosynclinal eastern-assemblage rocks and eugeosynclinal westernassemblage rocks. The exposed units are tarly Canbrian to Holocene sedimentary, igneous, and metamorphic rocks. The Paleozoic section is thick and structurally and litiologically complex. The Early Cambrian to Devonian strata consist of contrasting facies juxtaposed along thrust fauls in the eastern part of the sheet. The unics include:

(1) Rocks of the carbonate (miogeosynclinal) ard transitional assemblages consisting of carbonate rock and minor amounts of shale and quartzite.

(2) Rocks of the siliceous and volcanic (eugeosynclinal) assemblage consisting mainly of chert and clastic sedidentary rock, voicanic Elows, and pyroclastic rocks. 
Most of the Winnemucca guadrangle area sheet lies within the Antler orogenic Belt described by Roberts et al. ${ }^{10}$ in a region that underwent folding, faulting, and thrusting in Late Devonian and Early Mississippian. This orogeny culminated in a complex thrust sequence that placed the clastic and volcanic assemblage over the carbonate seguence. Numerous precious and base metal ore deposits are confined to the crushed rock along the tircust. plate or the carbonate rocks within the lower plate of the thrust.

From Late Mississippian to Permian, the area was eroded to produce coarse clasti.ss that were deposited to the east and west of the belt. The eroded ared itselt was covered with detritus. (The Battle Formation is a typical esample of this detritus.)

West of the belt, the lithr Logic assemblage consists of : nterbedded marine volcanic and pyrcojastic rock, limestone, chert, and $c^{+}$stic rocks. The Havallah Formation is one of the major units. These ziliceous and volcanic rocks were tectonically transported eastward in the map area along the Golcorda Thrust during the Sonoma orogeny of permian - Triassic time. Numerous nonuranium ore bodies are also located within this thrust belt.

Eürly Triassic deposits are diverse; most were derived from local uplifts within the orogenic region. Middla and Upper Triassic deposins are more uniform, consisting mostly of nearshore carbonates.

The Paleozoic and Triassic strata are intruded by numerous Jurassic and cretacenus plutonic rocks. These iansous rocks range from granite to diorite.

'lhe oldest Tertiary rocks are quartz monzonite to quartz diorite intrusives overlain by andesite and dacite flows. Rhyolite to quactz-latite ash-flow tuffs cover large parts of the area and are concentrated around the Fish Creek Mountains caldera. Associated with these unics are rhyolite Elows, intrurive rocks, and related sediments. Basaltic/andesite overlies the silicic volcanic rocks. The youngest volcanic rocks consist of younger rhyolite and basalt flows and widespread pliocene tuffaceous sedimentary rocks that cover larger parts of several valleys and portions of some mountain ranges.

The youngest deposits are Quaternary alluvial-fan and stream gravels, lake deposits, and windblown sand. These materials make up approximately 408 of the area; they are mainly confined to the basins between the range fronts. within the area are significant ore deposits of copper, gold, silver, tungsten, antimony, irisn, gypsum, barite, diatomite and less important 
deposits of mercury, lead, and zeolites. Although there are numerous mining districts, there are only scattered occurrences of low-grade uranium.

Twelve radioactive occurrences and rillerous recent uranium claims are shown on Fiy. 3. This map is based on reports by Garside ${ }^{13}$ and Larson and Beal. 14 The uranium is found in a wide variety of environments, but most of it occurs within igneous rocks or related sediments. Most occurrences contain only uranium; two deposits contain uranium and other metals.

Anomalous radioactivity is associated wirh featuzes in water laid tuff overlain by Tertiary rhyolite at Dacies Creek (T28N, R41E). At Iee Canyon (T30N, R52E), the Kei No. 2 claims contain uranium in siltstone, water-laid tuff, and Tertiary lake sediments. Similar occurrences exist at the Elazk Hills claims and Deerhead claims in T32N, R52E.

To the south, the Asphaltite prospect (T29x, K52E) contains uranium in strings and lenses of asphaltic pyrobitumen in northerly trending faults. The veins cut paleozoic clastics and contain associated vanadium.

Mid-Paleozoic carbonates contain autunite (?) near the foot of Cortez Canyon (T27N, R47E) in Crescent Vallzy. Bothi sides of the valley contain major gold mines in the Roberts Mountaiii thrust.

ismomalous radioactivity occurs at the C.L. Point clain group in the Kennedy District (T23N, R37E). The high radiometric readings were taken at the contact between granite and shale at the head of Say Canyon.

A now-inactive, dry oil well (T32N, R45E) encountered radioactive "black sands" at depths between $17.8 \mathrm{~m}$ to $27.1 \mathrm{~m}$. This probably represents a Reese or Humboldt River paleo-placer uranium deposit.

At the Copper King Mines (T34M, R51E) in the Maggie Creek District, secondary copper minerals are reportedly radioactive along a northwest-trending fault in an equivalent of the vinini Formation.

The old Jaw Bone Claim (T26N, R40E) is a minur uranium occurrence of unknown mineralogy. However, the anomalous radioactivity is probably associated with Fish Creek volcanic rocks.

Many hot springs exist within the area. Some contain anomalous mercury, and others are being investigated for geotlermal potential. Only the Golconda Hot Springs (T36N, R40E) has radioactive waters and s:- yer cleposits. Claims recently stakes for uranium ara the Granger clains (T36N, R40E) and the Bowles and Etchart claims (T27N, R42E). 


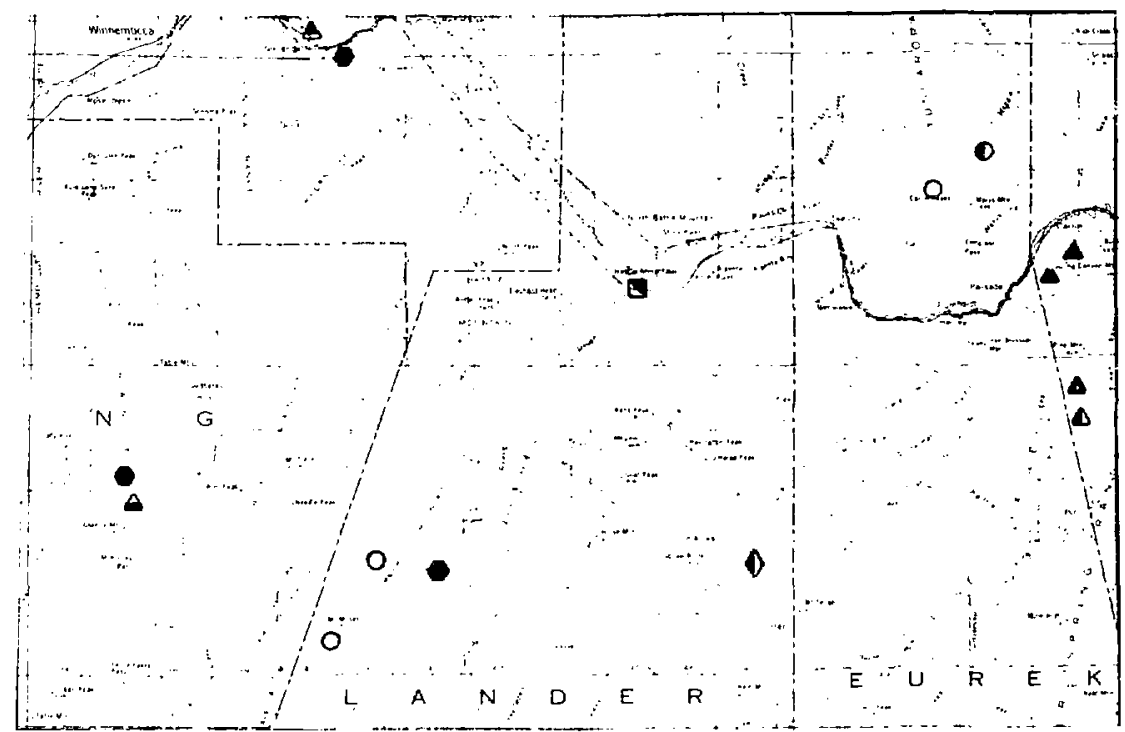

LEGEND

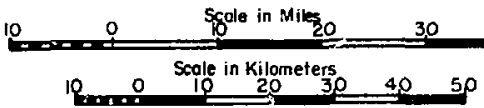

\begin{tabular}{|c|c|c|c|}
\hline & \multicolumn{2}{|c|}{ Pre-Tertiary Rocks } & \multirow{2}{*}{\begin{tabular}{|l}
$\begin{array}{c}\text { Tertiary - } \\
\text { Quafernary } \\
\text { Rocks }\end{array}$ \\
\\
sedimentary \\
rocks
\end{tabular}} \\
\hline & $\begin{array}{l}\text { sedimentary } \\
\text { volcanic a } \\
\text { mietomor phic } \\
\text { (low ronk irocks }\end{array}$ & $\begin{array}{l}\text { plufor, : } \\
\text { meramorphic } \\
\text { (high-rank) } \\
\text { rocks }\end{array}$ & \\
\hline $\begin{array}{l}\text { Uranium with } \\
\text { bose,precious } \\
\text { \& ferrous metals }\end{array}$ & 0 & & \\
\hline $\begin{array}{l}\text { Uranium with } \\
\text { other nineral- } \\
\text { izatlon minor } \\
\text { or absent }\end{array}$ & $\theta$ & & \\
\hline $\begin{array}{l}\text { Anomolous } \\
\text { radioactivity }\end{array}$ & $\Delta$ & $\Delta$ & $\Delta$ \\
\hline
\end{tabular}

O Minor prospect or occurrerice

- Spring or ground woter deposit

- Other uranium and/or radioactive occurrences or prospects reported D Placer deposit

Fig. 3. Uranium occurrence map. (Refs. 13, 14) 


\section{HYDROLOGY}

The area is drained by the Little and main Humboldt Rivers, the Reese River, Maggie Creek, Pine Creek, Rock Creek, and numerous ephemeral streams. The Reese River flows north toward Battle Mountain where it merges with the main Humboldt River. The Humboldt River flows west toward its cermination in the Humboldt Sink outside of the project boundary. The area not drained by this sygtem consists of numerous basins with no external outlet.

The arid to semiarid climate of the valleys is characterized by low precipitation and humidity and extreme variations in temperature. Large differences in precipitation occur between the valleys and ranges. The average annual precipitation varies from approximately $15.24 \mathrm{~cm}$ in the bottomlands to more than $63.5 \mathrm{~cm}$ in the higher mountains. Much of the precipitation occurs as snowfall during winter months and localized showers in summer. Unusually high thunderstorm activity occurred during the sampling period in summer 1976. However, the stream flow of the Humbolat River for summer 1976 was about one half of the average supply ${ }^{15}$ (see Fig. 4), a result of low winter prexipitation and light snowpack combined with above-average reservoir-usage.

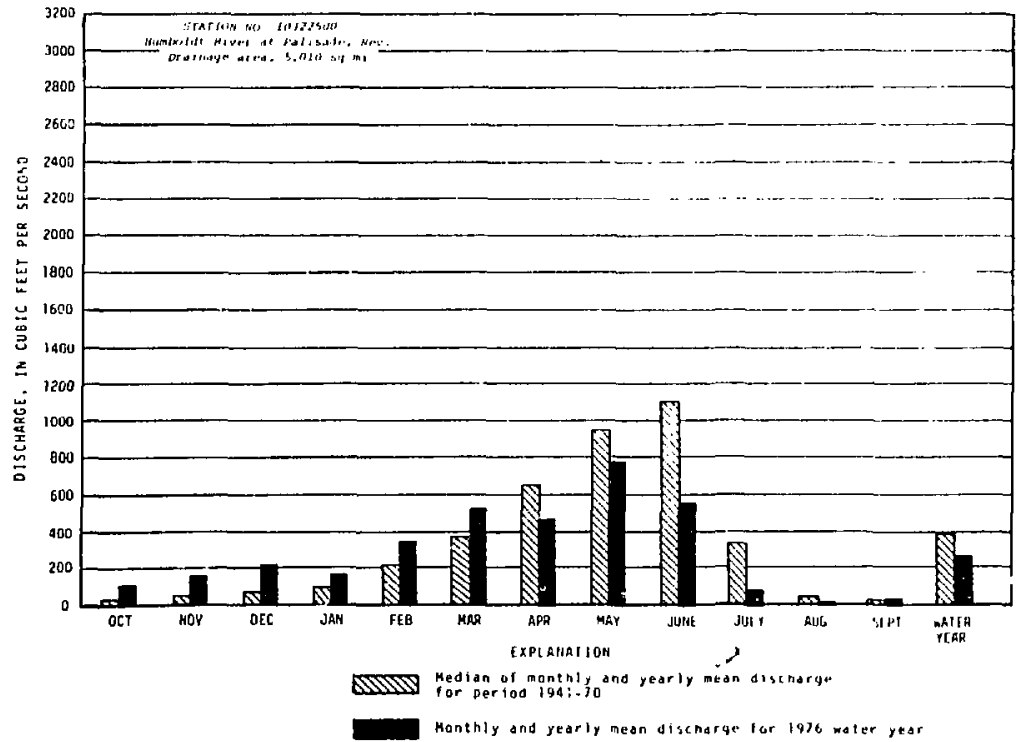

Fig. 4. Water survey data for 1976. (Ref. 15) 
Most wells are located in or near population centers. Observation of wells in these areas showed a general water-level decline in 1976. In undeveloped areas, water levels exhibited no sigrificant trends. Well sampling was biased toward the undeveloped arcas.

Published water data for springs are limited. however, some of the springs that were sampled appeared to have a less-than-normal flow rate that year.

\section{SAMPLE SITE SELECTION AND COLLECTION}

Proper selection of the sample site is the most important technical aspect of sample acquisition. The sites must be related to the geology and tile mobility of uranium in a given environment. In addition, becauss the uranium is measured in parts per million, seemingly insignificant sources of contamination could mask the natural background. Therefore, si:es were selected to represent the acquisition areas and minimize contamination by ensironmental pollution (f́arms, bridges, mines, etc.) and windblown and lake-bed deposits.

Water availatility has caused populacion and agricultural concentrations along the Humboldt and Reese Rivers. Thus, the Humboldt Basin valleys contain the most contaminants. In addition, these lowlands were once pluvial lake site: whose surface deposits are now weing dispergend by prevailing winds. Because of this, emphasis was placed on stream sampling along the range fronts. For relatively small drainages, a single sample site was selected at the canyon mouth. In larger drainages, samples were taken up the canyons and along tributaries to obtain representative coverage. Sampling on the fan aprosı and valley lowlands was biased toward ground-water samples; dry-stream samples were taken only along the most proninent, active-stream channels.

To compensate for windblown contamination, sediments were sieved to eliminate the finer materials. The material retained for analysis was the portion between $1000 \mu \mathrm{m}$ and $500 \mu \mathrm{m}$.

\section{QUALITY ASSURANCE}

\section{Fïeld Sa mpling}

Our fi:là quality-assurance program provides a reasonably high level of confidence in the quality of the samples returned to LLL for analysis. 
Contract specifications on sample collection impose strict requirements for methods and procedures. The specifications attempt to provide uniformity in the sampling process and, thus minimize errors. To encourage a high level of professionalism, sampling personnel are required to place a yellow, biodtgradable tag at the site and photograph the exact sample location. In addition, sampling personnel must ensure that the samples are not contaminated and represent the area being sampled and that the site locations ace indicated accurately on the field riap. The contract personnel must select suitable alternative sites should the primary site prove to be inadequate or inaccessible. Therefore, 311 persons collecting samples must be graduate geologists or have a minimum of two years formal education in geology plus one year field experience.

Lawrence Livermore Laboratory observers occasionaily accompanied the contract sampling crews and IIL geologists resampled approximately 58 of the project sites. (Sites selected for resampling were biased toward sites which were relocated by the contractor.) More than $95 \%$ of the resampled sites were accurately located on available maps or photos. The remaining sites were plotted within $182 \mathrm{~m}$ of the correct location.

The replicate ramples are reported in the tables by quality control $x$-reference numbers. Comparison of the sediment replicat results with the original samples shows an average variance of 128 for the uranium values. This 128 also takes into account the natural valiability of the sample. Therefore, the reported values are with in the same magnitude of uncertainty as the analytical variance.

Comparison of the water replicate samples with the original samples shows a variance of 18 . This is well within the analytical uncertainty of the system. The water replicate samples are discussed further in the section on geochemistry.

\section{Laboratory Analyses}

Inter laboratory comparison samples for uranium are distributed by DOE to the NURE laboratories. Analyses of these samples are collected and will be reported by D'silva, et al. ${ }^{16}$ It was not possible to analyze these samples concurrently with the reported data, but the same calibration factors and data processing system was used. The results should, therefore, be indicative of the accuracy and precision of the Wiunemucca Reconnaissance 
Table 1. Delayed neutron assay for uranium analyses of DOE inter laboratory comparison samples.

\begin{tabular}{|c|c|c|c|c|c|}
\hline & \multicolumn{2}{|c|}{ water } & \multicolumn{3}{|c|}{ Sediment } \\
\hline & A2, & $\mathrm{B} 2$, & $\mathrm{R} 1$, & Sl, & $\mathrm{Tl}$, \\
\hline & ppb & $\mathrm{ppb}$ & ppm & ppm & ppm \\
\hline Number of analyses & 7 & 7 & 9 & 9 & 9 \\
\hline Recommended value ${ }^{a}$ & 0.98 & 9.98 & 5.33 & 11.2 & 96.2 \\
\hline Mean value ${ }^{b}$ & 1.12 & 10.4 & 5.32 & 10.7 & 92.9 \\
\hline $\begin{array}{c}\text { Standard deviation } \\
\text { measurement, } 8\end{array}$ & 6 & 3 & 5 & 4 & 2 \\
\hline Bias, $\pm z$ & +14 & +4 & +0.2 & +4.7 & +3.6 \\
\hline
\end{tabular}

${ }_{\text {Recommended values are averages of analyses by three independent }}$ laboratories.

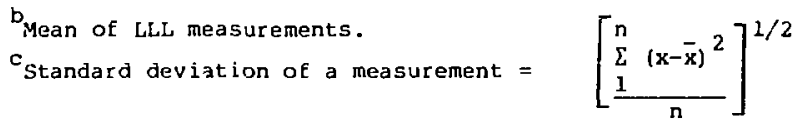

data. The comparison sample data are summarized by $c$. Smith of the Nuclear Chemistry Division (Table 1 ).

\section{GEOCHEMISTRY}

A logarithmic histogram and a cumulative-probability curve for uranium concentrations are provided for both water and sediment samples. An additional logarithmic histogram and cumulative probability curve is provided for thorium concentration in sediment samples. (They are included in Appendix A.) These statistical plots were generated to comply with DoE specifications. Representing and interpreting large data sets where individual samples must be compared with different threshold values is a problem in a large-scale drainage survey of a range of rock types. Gouett et al. 17 have shown that logarithmic transformations of large geochemical survey data, such as the Winnemucca quadrangle, cause enhancement of the background populations and supgression of the anomalous population in the overall statistical distribution. Therefore, pcpulation recognition and sorting is vital to the statistical interpretation. As a result, this report is intended to be a preliminary evaluation and not a detailed discussion of the data. 


\section{Sedinent Samples}

The basic probiem in reviewing the data for such a large-scale survey is to sort the sediment uranium concentrations into ammalous and background values. Often in such surveys, high value samples li.e. greater than two standard deviations $f$ rom the mean) are generally considered anomalous. Yet not all high values may wartant attention, and some lesser values inay reflect areas of interest. This is especially trur in the winnemucca quadrangle area because the mean and standard deviation of uraniun concentrations (Fig. A-2 in Appendix A) are not caiculated for a single homogenous population of samples but from a distribution that is composed of a highly varied and mixed population. However, time did not permit hand sorting the data into discrete populations. In addition, multivariant statistical programs are not yet developed to adequately handle NuRE data. Th:cefore, this study was arbitrarily restricted to samples with $>5$ ppm usaniun $i_{r}$ an attempt to define a useful sample of the population.

Logarithmic transformations were performed on elemental concentrations of all sediment samples having uranium concentrations greater than 5 ppm. No significant linear correlations were found between the uranium crncentration and that of ot:her elements. This suggests that uranium mineralogy in the Winnenucca sheet is quite diverse. It also hints at the varied distribution of uranium within the area as a consequence of the mixed populations. Samples with m.re than 5 ppm uranium were plotted in relation to rock type (Fig. 5). Th is amounted to 132 points out of a population of 1032 (138). The majority of these samples are concentrited in or near outcrops of rhyolitic ash falls and flows and silicic intrusives. Uranium values between 5 ppin and 10 ppm are not unusual for these rock types (Ref. 18) and values encountered here may be background for these samples.

Uranium tends to be oxidized to the comparatively soluble uranyl ion, permitting easy mobilization in surficial processes. Uranium is lost slowly from rhyolitic rocks over a long period of time while their thorium content shows no significant changes. Zielinski ${ }^{19}$ has shown that the rate of loss varies with parent-rock composition, but concentration of the mobilized uranium may then constitute an area that warrants interest. Therefore, in defining an anomaly for this subset of the population the ratio of relatively insoluble thorium to soluble uranium was considered. 


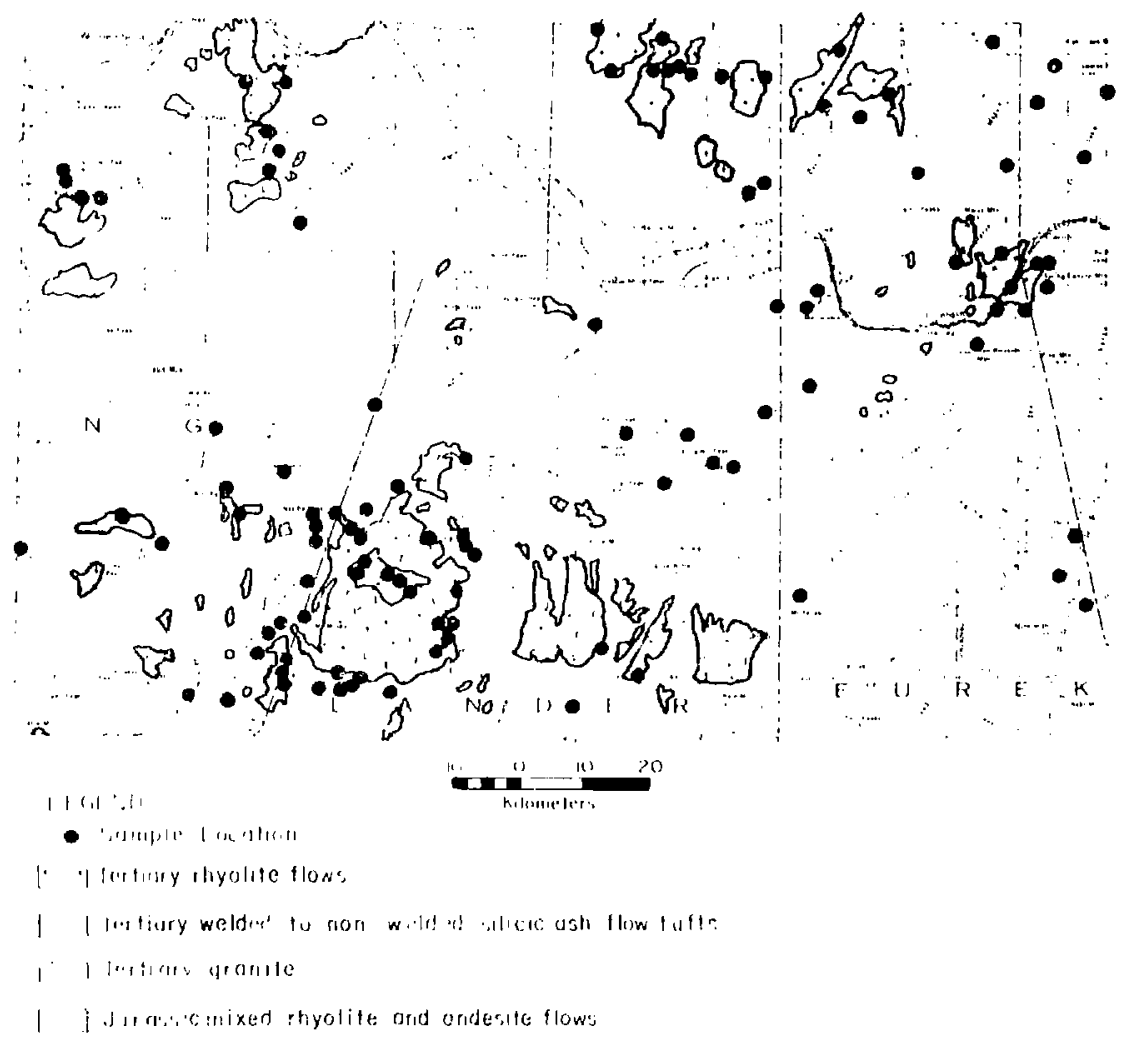

Fig. 5. Distribution of samples with urarium concentrations of more than 5 pprn.

The variation of uranium to thorium content was computed as the Th/U contcentration ratio for samples with a uranium content more than 5 ppm. Samples having the lowest Th/U (arbitrarily chosen as <2) were plotted. (See Fig. 6.) This sampling of 32 sites shows approximately.908 correlation with fluvial and lacustrine beds. First-component and correlation analysis show little association of uranium with other elements although this would be expected because sedimentary rocks generally show a high element variability. 


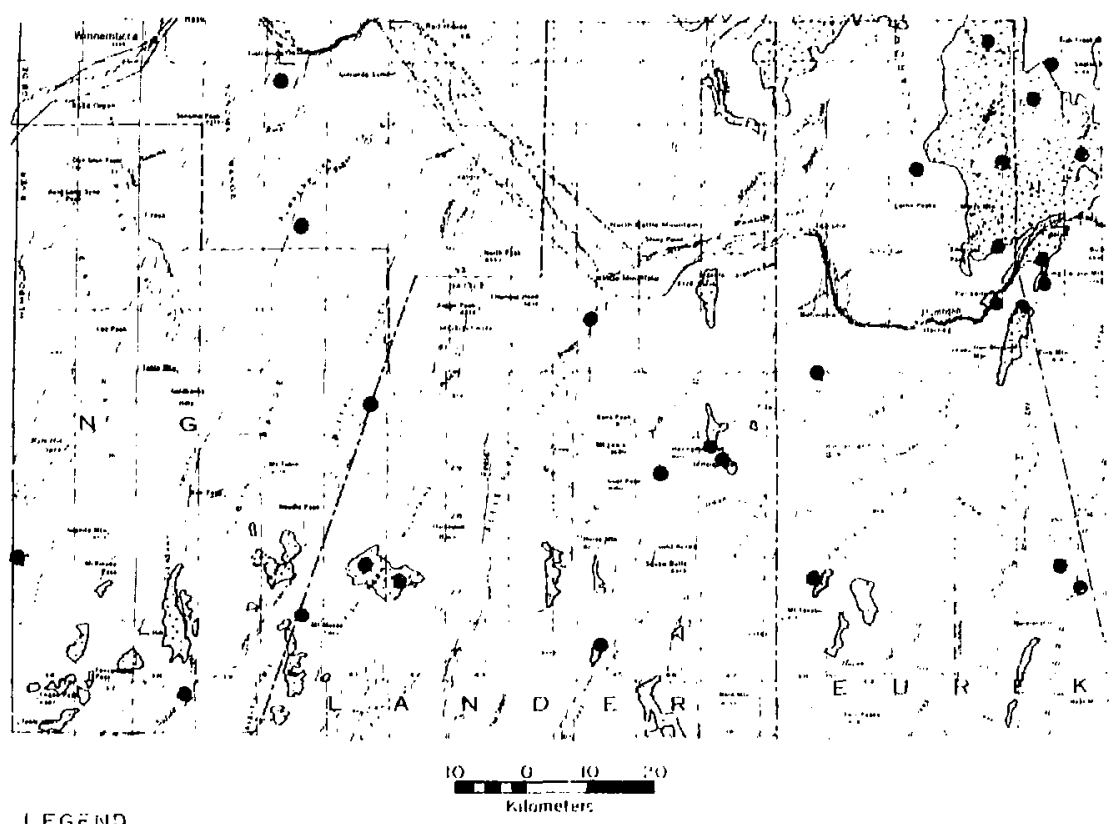

LEGriND

- Sumple location

Miocene lacustrine and fluvial depusits

Fig. 6. Distribution of samples with uranium concentrations of more than $5 \mathrm{ppm}$ and $\mathrm{Th} / \mathrm{U}$ less than 2.0 .

The low Th/U values were deleted from the sample set with more than 5 ppn uranium, and correlatinn coefficiente were computed for the ramaining 100 samples. These results show a correlation of uranium wit') thorium, potassium, rubidium, and cerlum. The comparatively high Th/U ratio in these sampleg suggests that the uranlum is asgociated with the insoluble thorfum, either in primary resistate phases such as zircon, sphene, and apatite, or as secondary Fe-Ti-mn oxida phases. Zielinsk1 19 has shown these accessory minecal phases of rhyolitic volcanic rocks to be uranium concentrators. The presence of these resistate minerals also explains uranium's association with cerium. Thorium in addition to being concentrated in resistates is also adsorbed in clays which may explain the potassium and rubidium correlation. Correlation 
of cubidium, potsssium and cerium with uranium is also suggestive of an alkalt-ric'r Igneous assemblage.

Because these elemental relations agree well with the known geochemistry of rhyolites and gilicic intrusives, the associated nonsolubie uranium values might be taken as background. The anomalieg on the winnemucca sheet would then be samples contalning $l o w T h / U$ and high uranium concentrations.

The most wismon enviconment for the concentration of this leached uranium Is the Miosene fluvial-lacustrine beds derived mostly from sillclc ash flow and falls. The multielement data shows an associatior. of some samples with potassium and aluminuin, suggesting clay-uranium complexes, and some sith bromine, suggesting either an organic or shale association with uranium.

Sampleg not associated with the Miocene beds are either younger lake beds or alluvium having similar environments of deposition. The only exceptions are some samples below precious and base metal occurrences known to contair, urantum and a few samples below vinini siliceous volcanic rock and their equivalents. The areas delineated by these samples contain all but three of the known uranium occu, rences shown in Fig. 3. Two of the three remaining areas have uranium sample concentrations of less than 5 ppin and were thus not part of the sample siet. 'ithe third area was not sampled in cloge proximity to the known uranium occurrence.

Defining anomaloug uranium of less than 5 ppm for the remaining population was difficult because of high variable-element concentrations in a mixed assemblage of eugeosynclinal, miogeosynclinal, and transttion rocks. However, some correlations are worth noting. Samples in a predominantly miogeosynclinal carbonate terrain contaln little uranium but variable godium and high ralcium. This is conslstent with a deep-water carbonate environment. The euyensynclinal assemblage displays medial uranium values associated with rare earths. The elevated rare-earth values would be expected for an island arc, chert, shale assemblage. Uranium values in this environment are difficult to Interpret, not only because of the variance of rock types but also because of the complex made of origin.

\section{Conclustions:}

- Uranium geochemistry of the Winnemucca quadrangle is diverse.

- High concentrations (more than $5 \mathrm{ppm}$ ) of uranium are associated mainly with rhyolitic ash falls and flows and silicle intrusives. 
- The characteristic abundance of uranium in these rock types is higher than the mean value of uranium computed for all the winnemucca data. Hence, high concentrations of uranium are normal for this subset of the population.

- Low Th/ $U$ values delineate anomalous areas of possible interest. These areas are mainly fluvlal-lacustrine units.

- Intrepretation of concentrations of less than $5 \mathrm{ppm}$ uranium for the remaining population is difficult because of the diverse rock types and modes of origin.

- Sorting of the population and multivariant coefficient analysis should be applied for complete interpretation of the data.

- Interpretation of eiement variations associated with uranium requires the additional consideration of the influence of physiographic and geographic factors upon the distribution.

These conclusions are generalizations for the Winnemucca quadrangle and may not be valid for a diffezent survey area.

\section{Water Samples}

The variations of temperature and precipjtation mentioned earlier may produce wide seasonal differences in surface-water runoff that result in temporal variations in uranium concentrations. These tluctuations are verified by the 1977 Weather Bureau data For the main river system (Fig. 4). Benson and Leach ${ }^{20}$ have shown that fluctuations in seasonal weather conditions, irrigation water usage, and ground-water flow impose an increase or decreuse in uranium concentrations and changes in the mas $s$ of dissolved solids carried by surface waters.

To minimize the temporal factor, the system was sampled over a short period during summer 1976. Resampling of some sites by LLL shows variations in the uranium content to be within detection limits (Table 2). Because the river discharge data shows that a low-flow period occurred during this time, the uranium concentrations are probably at the naximum values for that year. For this reason, further sampling during a wetter period might result in uranium values lower than observed in summer 1976.

Meager or non-existent ground-water discharge to the Humboldt River during the sampling period is thought to explain why the river does not 
Table 2. Water Analysis; Main Humboldt River.

\begin{tabular}{lcccccc}
\hline $\begin{array}{c}\text { Sample } \\
\text { No. }\end{array}$ & Temp & pH & $\begin{array}{l}\text { Soec. } \\
\text { cond. }\end{array}$ & $\begin{array}{l}\text { Alk. } \\
\text { tot. }\end{array}$ & U ppo & Date \\
\hline 7441 & 19.5 & 8.3 & 896 & 240 & 6.0 & $8 / 25 / 76$ \\
$7547^{\mathrm{a}}$ & 7.0 & 8.5 & 845 & 220 & 5.9 & $10 / 19 / 76$ \\
7442 & 25.0 & 8.5 & 650 & 20 & 5.1 & $8 / 25 / 76$ \\
$7546^{\mathrm{a}}$ & 10.0 & 8.5 & 508 & 160 & 4.8 & $10 / 08 / 76$ \\
7443 & 18.0 & - & 868 & 220 & 4.0 & $8 / 25 / 75$ \\
$7545^{\mathrm{a}}$ & 6.0 & 8.1 & 950 & 220 & 4.6 & $10 / 18 / 76$ \\
\hline
\end{tabular}

auplicate of previous sample taken at same location.

reflect the uranium content of the rock through which it flows. The uranium-rich areas on the east end of the sheet were not detected in the data. In several areas, uranium-concentration values on the main Humboldt River are irregular. These areas, such as Iron Point, appear to be positively related to irrigation. Benson and Leach ${ }^{20}$ have shown that significant modification of the stream flow and chemistry occurs because of agricultural practices. These changes in hydrochemistry nay mask any ansmalous uranium-bearing waters entering the system. The uranium concentration may be a result of evaporation and evapotranspiration of irrigation water.

Benson and Leach ${ }^{20}$ have also shown that comparison of uranium concentrations with chloride conrentrations can be used to evaluate possible concentrations or dilution effects. This method assumes that mobility is the same everywhere. Aithough uranium increases snarplÿ across the agricultural areas (usually more than $5 \mathrm{ppb}$ ), $\mathrm{U} / \mathrm{Cl}$ ratios (generally less than 2) show only a weak and irregular trend of increase with transport distance; irregularities in tiis trend are probably related to river diversion points for irrigation systems. Thus, the uranium concentration data for the main Humboldt River has limited usefulness.

In the head-water tributaries of the Humboldt River system, the concentration of uranium is typically less than $2 \mathrm{ppb}$, and often below $1 \mathrm{ppb}$. Higher concentrations (generally more than $5 \mathrm{ppb}$ ) occur in regions wher acidic waters react with surficially exposed quartz monzonite-granodiorites and acid volcanic rock, thus releasing uranium. The area of highest uranium concentration occurs around the edge of the Fish Creek Mountain volcanic rocks. This region was defined earlier as having high uranium values in the 
sedinents associated with the volcanic rocks. Waters from this area have relatively low $\mathrm{U} / \mathrm{Cl}$ ratios. Of more interest are the regions containing the high $\mathrm{U} / \mathrm{Cl}$ (more than 4) and high uranium values. One such area includes the Shoshone and cortez Mountains in which the water sites are related to acidic igneous rocks. One sample containing $36.7 \mathrm{ppb} u r a n i u m$ and $\mathrm{U} / \mathrm{Cl}$ equal to 4.5 is below a known mineralized area.

Also of interest are some springs and streams in the northern part of the area with uranium concentrations more than $5 \mathrm{ppm}$ and high U/Cl ratios; these drain the Miocene lacustrine and fluvial beds mentioned earlier.

Defining other regions of interest in the project area by spring and tributary water sampling is somewhat limited by the irregular spatial djstribution of the sites.

A low-density factor was used in the selection of well sites for sampling. Of those wells selected for visitation, many were either dry or not pumping. Hence, only limited well data is available. However, one location did show $10 \mathrm{ppb}$ uranium. This uranium concentration was probably from fluids interstitial to Tertiary sediments containing anomalous uranium.

Conclusions:

- The main basinal stream (i.e., the Humboldt River) shows an irreguiar increase in uranium concentration downstream.

- The river does not reflect the uranium content of the rocks through which it flows, and the data did not indicate the uranium occurrence on tive east edge of the quadrangle.

- Significant increases in uranium may be related to agricultural modification of the stream flow. Therefore, the Humboldt River water data has limited usefulness.

- U/Cl ratios can be used to evaluate the effects of evaporative concentration.

- Spring and tributary water has detected high amounts of uranium leaching from acid intrusives and silicic volcanic rocks and related sediments.

- Defining areas of irterest by spring and tributary sampling is limited by the irregular spacial distribution of sites. 


\section{ACKNOWLEDGMENTS}

The data herein are the cumulative result of effort by many individuals too numerous to mention without whose support this report would not have been possible. Geochemist D. Leach designed the Humboldt River Basin sampling program of which the winnemucca sheet is a part. The author fielded the sainpling program and was assisted by P. Bowen and other technicians from the M.E. Department. Processing and analysis of the sediment, rock, and water samples were performed under the direction of $C$. Smith; $w$. Hutchin coordinated sampling processing, R. Van Konynenburg performed neutron activation analysis, $E$. Peck and A. Langhorst conducted emission spectrometry, and R. Lim was responsible for special chemistries. G. McMillan developed and supervised data processing and data base management functions were performed by $B$. Gumm. Special thariks go to S. Grotch, B. Holder, R. Carpentes, and J. Attebery for the data tables, hiscr.grams, overlays, and report: coordin.tior. Their persistent dedication to their work enabled the author to meet a tight dealline. Geologist L. Garside and research associate D. Trexler of the Nevada Bureau of Mines provided help and information on uranium and geology in Nevada. $R$. Stone critically reviewed the manuscript. Ground water site selection, sample acquisition, field measurements, and hydrology information were provided by the Desert Research Institute. Sincere appreciation is also expressed to the land owners, Forest Service, and Bureau of Land Management personnel who granted access to the lands under their control so that the survey could be completed. 


\section{REFERENCES}

1. K. P. Puchlik, Roach Lake Basin Orientation Study, Nevada; Lawrence Iivermore Laboratory Hydrochemical Reconnaissance, Rept. TKCID-17681-P (1977), GJBX-48 (78).

2. K. P. Puchlik, "Collection of wet and Dry Stream Sediment Samples", from the Symposium on Hydrogeochenical and Strean Sediment Sampling; Grand Junction, Colo., Lawrence Livermore Iaboratory Preprint UCRL-79246 (1977).

$\therefore$ C. F. Smith, Instrumental Neutron Aativation Analysis for the NURE Rydrogeochemical Survey, Lawrence Livermore Laboratory, Rept. LCRL-79709 (to be published).

4. R. Gunnick and J. B. Niday, Computerized Quantitative Analysis by Gamma Ray Spectrometry, Description of the GayaNaL Program, Lawrence Livermore Laboratory, Rept. UCRL-51061, Vol. 1 (1972).

5. R. E. Heft and W. H. Martin, NADAS and MERGE-Computer Codes for Processing Neutron Activation Anaylsis Data, Lawrence Livermore Laboratory, Rept. UCRI-52249 (1977).

6. G. G. McMillan and R. D. Carver, NURAB - A System for Processing Neutron Activated Samples, Lawrence Livermore Laboratory, Rept. UCRL-80259 (1978) (to be published).

7. C. R. Willden, "Geology and Mineral Deposits of Humboldt County, Nevada," Nevada Bur. Mines BulI. 59 (1964).

8. J. H. Stewart, E. H. Mckee, and H. K. Stager, "Geology and Mineral Deposits of Lander County, Nevada," Nevada Bur. Mines and Geol. Bull. $88(1977)$.

9. M. G. Johnston, "Geology and Mir iral Deposits of Pershing County, Nevada," Nevada Bur. of Kines Bull. 99 (1977).

10. R. J. Roberts, K. M. Montgomery, and R. E. Lehnes, "Geology and Mineral Resources of Eureka County, Nevada," Nevada Bur. Mines and Geol. Bull. 64 (1967).

11. A. E. Granger, M. M. Bell, G. C. Simmons, and F. Lee, "Geology and Mineral Deposits of Elko County, Nevada," Nevada Bur. of itides and Geol. Bu11. 54 (1957).

12. R. J. Roberts, P. E. Hotz, J. Gilluly, and H. G. Ferguson, "Paleozoic Rocks of North-Centical Nevada," An. Assoc. Petrol. Geol. Bull. 42, 12, p. 2813-2857 (1958). 
13. L. J. Garside, "Radioactive Mineral Uccurrences in Ne:ada," Nevada Bur. Mines and ceol. Bull. BI (1973).

14. L. Larson and L. Beal, "Great Basin Geologic Framewr :k and Uranium Favorzility, Department of Energy, Open File Rept BFEC-GJo-76-020-E (197B).

15. UsGs, Water Resources Data For Nevada, Water Year 976, U.S. Geological Sur'Jey, Water Data Report NU-76-1.

16. A. P. D'Silva, M. A. Floyd, and W. J. Haas, Jr., Multilaboratory Ana.'ytical Quality Control for the Hydrogeochemical and Stream sediment Reconnaissance, publisheã monthly by Ames Laboratory, Iowa State University, Ames, Iowa. DOE open file repositories.

17. G. S. Gouett, W. Goodfellow, R. Chapman, and C. Chork, "Exploration Geochemistry-Distribution and Recognition of Anomalies," Math. Geol. I, $5-6,(1975)$.

18. J. W. Rogers and J. S. Adams, "Uranium," in Handbook of Geochemistry 4 , 4, K. H. Wedepohl, Ed. (Springer-Verlag, New York, 1969).

19. R. A. Zielinski, "Uranium Abundances and Distribution in Associated Glassy and Crystalline Rhyolites of the Western U.S.," Geol. Soc. of Amer. Bull. 89 (1078).

20. L. V. Benson and D. L. Leach, Hydrogrochemistry of Uranium in the Walker Lake River Basin, California and Nevada, Lawrence Livermore Laboratory 上 repr int UCRL-79282 (1977). 


\section{BIBLIOGRAPHY}

Bredehoeft, J. D., 196j, Hydrogeology of the Lower Humboldt River Basin, Nevada, University of Nevada Desert Research Institute Technical Report No. 3.

Cohen, Philip, 1964, A Brief Appraisal of the Ground-Water Resources of the Grass Valluu Area, Humboldt and Pershing Counties, Nevada ; Nevada Dept. Conserv. Nat. Resources, Water ResourcesReconn. Ser. Report 29. Erickson, R. L., and Marsh, S. P. 1974, Geologic map of the Iron Point quadrangle, Humboldt County, Nevada: U.S. Geol. Survey Geol. Quad. Map GQ-1175.

Ferguson, H. G., Roberts R. J., and Muller, S. W., 1952 Geology of the Golconda quadrangle, Nevada: U.S. Geol. Survey Gæol. Quad. Map GQ-15. Gilluly, James, and Masursky, Harold 1965, Geology of the Cortez quadrangle, Nevada, with a section on Gravity idd aeromagnetic surveys, by D. H. Mabey: U.S. Geol. Survey Bull. 1175.

Gilluly, James, 1967, Geologic map of the winnemucca quandrangle, Pershing and Humboldt Counties, Nevada: U.S. Geol. Survey Geol. Quad. Map GQ-656.

Hotz, F. E., and Willden, Ronald, 1964, Geology and mineral deposits of the osgood Mountains quadrangle, Humboldt County, Nevada: U.S. Geol. Survey Prof. Paper 431.

Jerome, S. E., 1964, Mineral and Water Resources of Nevada: Nevada Bur. of Mines Bull. 65, p. 9-10; also U.S. B8th Cong., 2d Sess., Senate Doc. No. 87.

Lawrence, E. F., and wilson, R, V., 1962, Mercury occurrences in Nevada: Nev. Bur. Mines Map 7.

Lawrence Livermore Laboratory, Dec. 1977, Hydrochemical and Stream-Sediment Reconn. Survey of NURE, Quarterly Pronress Report GJBX-45(78) . Leach D., Puchlik, K., 1976, Dispersion of Uranium and Selected Trace Elements in Playa Basins: Proceedings of the Internaticnal Geological Congress, Syaney, Australia, v. 2, p. 448. (UCRL-77853) .

Loetz, O. J., and Phoenix, B. A., 1955, Geology and ground-water resources of Buena Vista Valley, Pershing County, Nevada, with a statement on Reconnaissance land classifjcation of Buena Vista Valley, Pershing County, Nevada, by H. G. Mason: Nevada Water Resources Bull. 13. 
McKee, E. H., 1970, Fish Creek Mountains tuff and volcanic center, Lander County, Nevada: U.S. Geol. Survey Prof. Paper 681.

McKee, E. H., and Stewart, J. H. 1969a, Geologic map of the McCoy quadrangle, Lander County, Nevada: U.S. Geol. Survey open-file map. Merriam, C. W., and Anderson, C. A., 1942, Reconnaissance survey of the Roberts Moutains, Nevada: Geol. Soc. America Bull., v. 53, No, 12, pt. 1, p. 1675-1727.

Morrison, R. B., and Frye, J. C., 1965, Correlation of the midale and late Quaternary successions of the Lake Lahontan, Lake Bonneville, Rocky Mountain (Wasatch Range), Southern Great Plains, and eastern midwest areas: Nevada Bur. Mines Rept. 9.

Muffler, L. J. P., 1964 Geology of the Frenchie Creek quandrangle, north-central Nevada: U.S. Geol. Survey Bull. 1179.

Muller, S. W., Ferguson, H. G., and Roberts, R. J., 1951, Geology of the Mount Tobin Quadrangle, Nevada: U.S. Geol. Survey Geol. Quad. Map GQ-7. Puchlik, K. P., 1977, Cave Valley Orientation Study, Nevada; Lawrence Livermore Laboratory Hydrogeochemical Reconnaissance Report, UCID-16911-P. GJBX-19(78).

Puchlik, K. P., 1977, Roach Lake Basin Orientation Study, Nevada; Lawrence Livermore Laboratory Hyarochemical Reconnaissance Report, UCID-17681-P. GJBX-48 (78) .

Puchlik, K. P., 1977, Collection of Wet and Dry Stream Sediment Samples, from the Symposium on Hydrogeochemical and Stream Sediment Sampling; Grand Junction, Colo., Lawrence Livermore Laboratory Preprint UCRL 79246. GJBX-77 (77) .

Roberts, R. J., 1951, Geology of the Antler Peak quadrangle, Nevada: U.S. Geol. Quad. Map GQ-10.

Schrader, F. C., 1934, The McCoy mining district and gold veins in Horse Canyon, Lander County, Nevada: U.S. Geol. Survey Circ. 10.

Sharp, B. J. 1956, Uranium deposits in volcanic rocks of the Basin and Range province, in Page, L. R., stocking, H. E., and Smith, H. B., Contributions to the Geology of uranium and thorium by the United States Geological Survey and Atomic Energy Commission for the United International, Cont. on peaceful uses of atomic energy, Geneva, Switz., 1955: U.S. Geol. Sulvey Prof. Paper 300.

Silberling, N. J., and Roberts, F. J., 1962, Pre-Tertiary stratigraphy and structure of northwestern Nevada: Geol. Soc. Anerica Spec. Paper 72. 
Stewart, J. H., 1969, Geologic map of the Battle Mountain and part of the Dunphy quadrangle, Nevada: U.S. Geol. Survey open-file map. Stewart, J. H., 2969a, Geologic map of the Carico lake quadrangle Lander County, Nevada: U.S. Geol. Survey open-file map.

Turekian, K., and Wedephol, K. H., 1961, Distribution of the elements in some major rock units of the earths crust: Geol. 5oc. of Amer.. v. 72. Wallace, R. E., Silberling, N. J., Irwin, W. P., and Tatlock, D. B., 1959, Preliminary geologic map of the Buffalo Mountain quadrangle. Nevada: U.S. Geol. Survey MF-220.

Washburn, R. H., 1970, Paleozoic steatigraphy of Toiyabe Range, southern Lander County, Nevada: Am. Assoc. Petroleum Geologists Bull, v. 52, No. 2 , p. 275-284. 
APPENDIX A

DATA ORGANIZATION AND DEFINITIONS

A-1 


\section{DATA PRESENTATION}

\section{Organization}

The numerical results of this reconnaissance survey are presented in 3 hardcopy tables (Appendix B), in microfiche tables (back cover pocket), and in 5 vellum overlays (back cover pocket). In addition, frequency histograms and cumulative frequency plots of the logarithmic of the uranium and thorium concentrations plotted on the overlays are included in the back of Appendix A.

\section{Hardeopy Tables}

Selected results of this investigation are presented in the 3 tables in Appendix B. Additional data on the trace elements content for sach of the samples is reported in the microfiche tables. The titles and data reported in each of the three tables is given below.

Sediment analysis, dry and stream sites given in Table $B-1$.

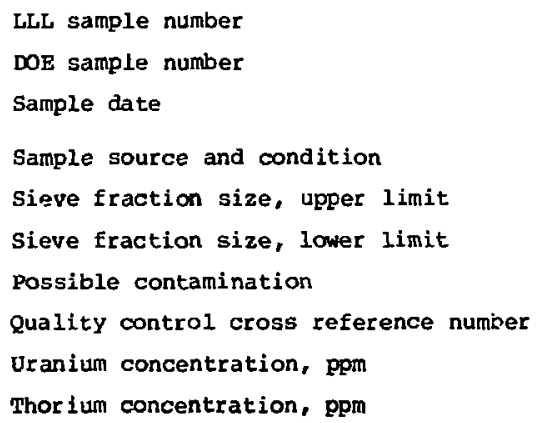


Water analyses; river, stream and lake sites given in Table B-2.

LLL sample number

DOE sample number

Sample date

Sample source and condition

water Temperature, ${ }^{\circ} \mathrm{C}$

$\mathrm{pH}$ meter

Specific conductance, $\mu$ mho/cm

Total alkalinity

Phenolphthalein alkalinity

Pussible contamination

Uranium concentration, ppb

Quality control cross reference site number

Water analyses; springs and wells given in Table B-3.

LLL sample number

DOE sample number

Sample date

Sample source and condition

Water temperature, ${ }^{o} \mathrm{C}$

Well depth-type-casing

pH meter

Specific conductance, $\mu m h o / \mathrm{cm}$

Total alkalinity

Phenolphthalein alkalinity

Possible contamination

Uranium concentration, ppb

Quality control cross-reference number 


\section{Microfiche Tables}

The additional element data gathered for each sample are presented in tables on microfiche film. These tables contain data from neutron activation analyses, special chemistry, and emission spectra analyses. The table titles are exactly as in the hardcopy tables, and the cclumnar entries of the hardcopy tables are repeated as the first part of each microfiche table. This is followed by the element values arranged in alphabetical order according to the element's proper name. Because of the amount of data, the tables are subdivideci into several parts presented on separate pages.

\section{Overlays}

Full-size vellum overlays for use with Natioual Topographic Map Series (NTMS) 1:250,000 scale $1^{\circ} \times 2^{\circ}$ quadrangle are located in the rear pocket of this report. These may be used with the commercially available NIMS map for visual display of the sampling site locations and uranium concentration relative to local geographic features. The NTVS map name and number is given on the overlay. To limit the number of over lays that must be generated for each map, the information presented has been divided into two major classes - waters and sediments. The site number uranium concentration and thorium concentration of each sample are plotted on separate sheets for each class. Different sample site types (stream vs spring or well water, or wet vs dry sediment) are distinguished by using different symbols in association with the site number. The site type symbol is plotted over the geographic location with the site number plotted beside it. The corresponding concentration range value is indicated in a separate overlay by a symbol whose shape and size varies with the range value. The symbol set employed here is a slightly modified version of that employed by the Geological survey of Canada in their hydrogeochemical surveys. Two sets of ranges are enployed because the average uranium trace element concentration is nearly a factor of $10^{3}$ larger in sediments than in natural waters. The range assignments are shown below. 


\section{Water Samples}

Uranium \{total\} concentrations

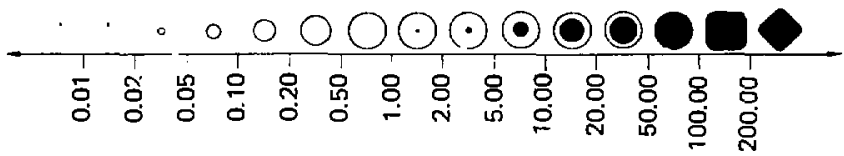

Parts per billion (ppb) by weight

- Less than $0.01 \mathrm{ppb}$ (or not detected)

Greater than $200 \mathrm{ppb}$

Fig. A-1. Uranium concentrations in water samples.

\section{Sediment Samples}

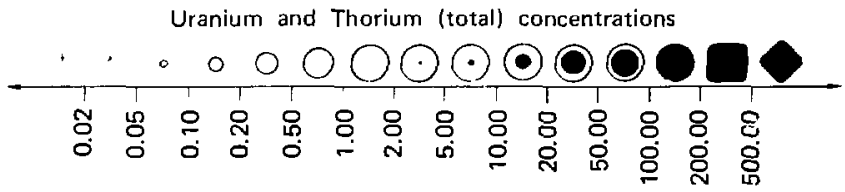

Parts per million $\{\mathrm{ppm}\}$ by weight

- Less than $0.02 \mathrm{ppm}$

(or not detected)

Greater than $500 \mathrm{ppm}$

Fig. A-2. Uranium concentration in sediment samples.

The overlays in the rear pocket are:

Overlay LA. Site Locations, Water Samples

Overlay 1B. Total Uranium Concentrations, Water Samples

Overlay 2A. Site Locations, Sediment Samples

Over lay 2B. Total Uranium Concentrations, Sediment Samples

Over lay 2C. Total Thorium Concentrations, Sediment Samples

\section{Histograms and Cumulative Brequency Plots}

Histograms and cumulative frequency plots of the uranium values shown in overlays $1 B$ and $2 B$ are given in Fig. A-3 (water samples) and Fig. A-4 (sediment samples). The Histogram and cumulative frequency plot of the thorium values shown in over lay $2 \mathrm{C}$ are given in Figure A-5. These are presented as the logarithm of the element concentrations. 
HIREEUCCA OUADPANCL---HeTEPS
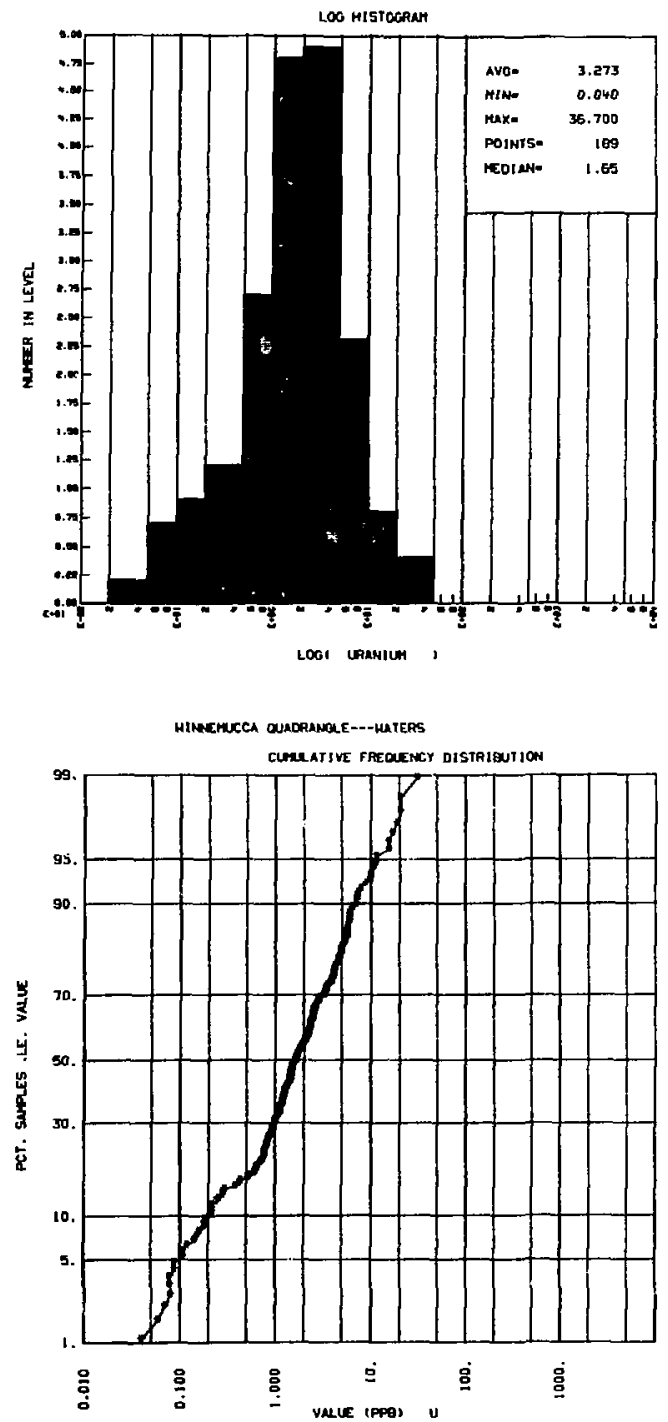

Fig. A-3. Histogram (a) and cumulative frequency distribution (b) of water samples plotted on over lay 18. 

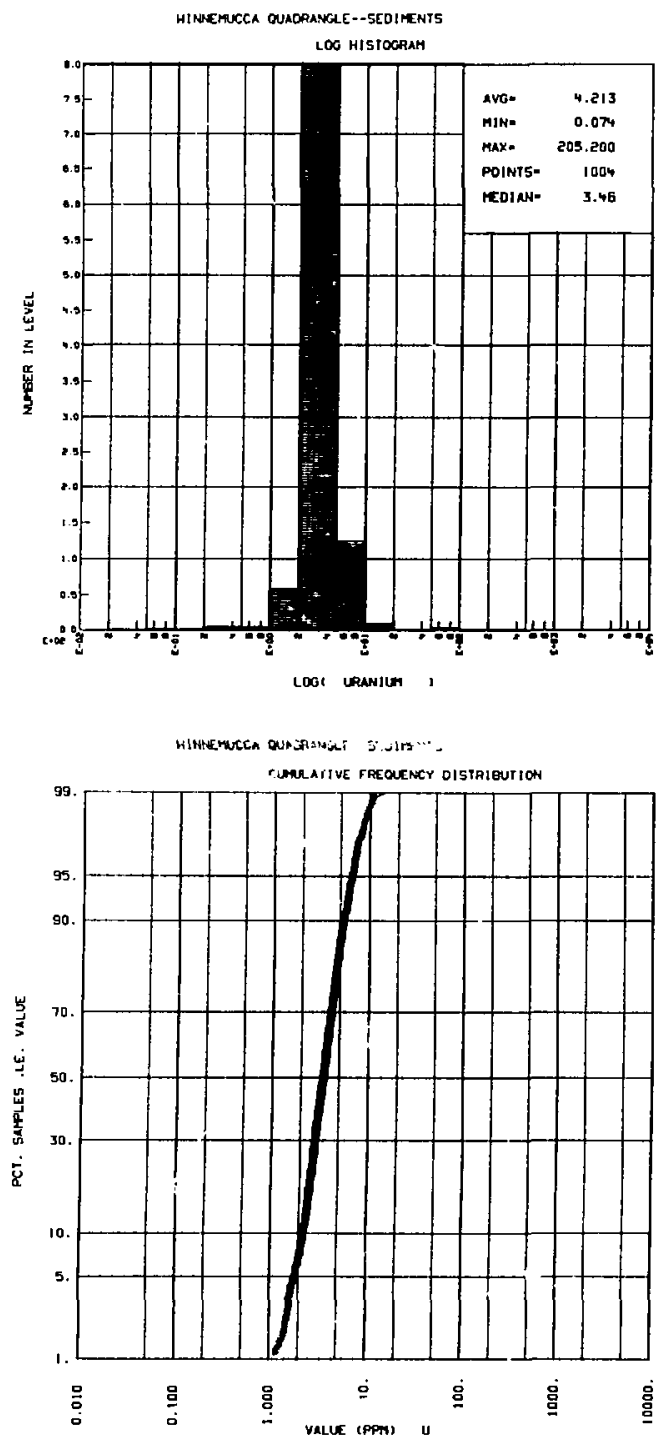

Fig. A-4. Histogram (a) and cumulative frequency distribution (b) of sediment samples plotted on overlay $2 B$. 

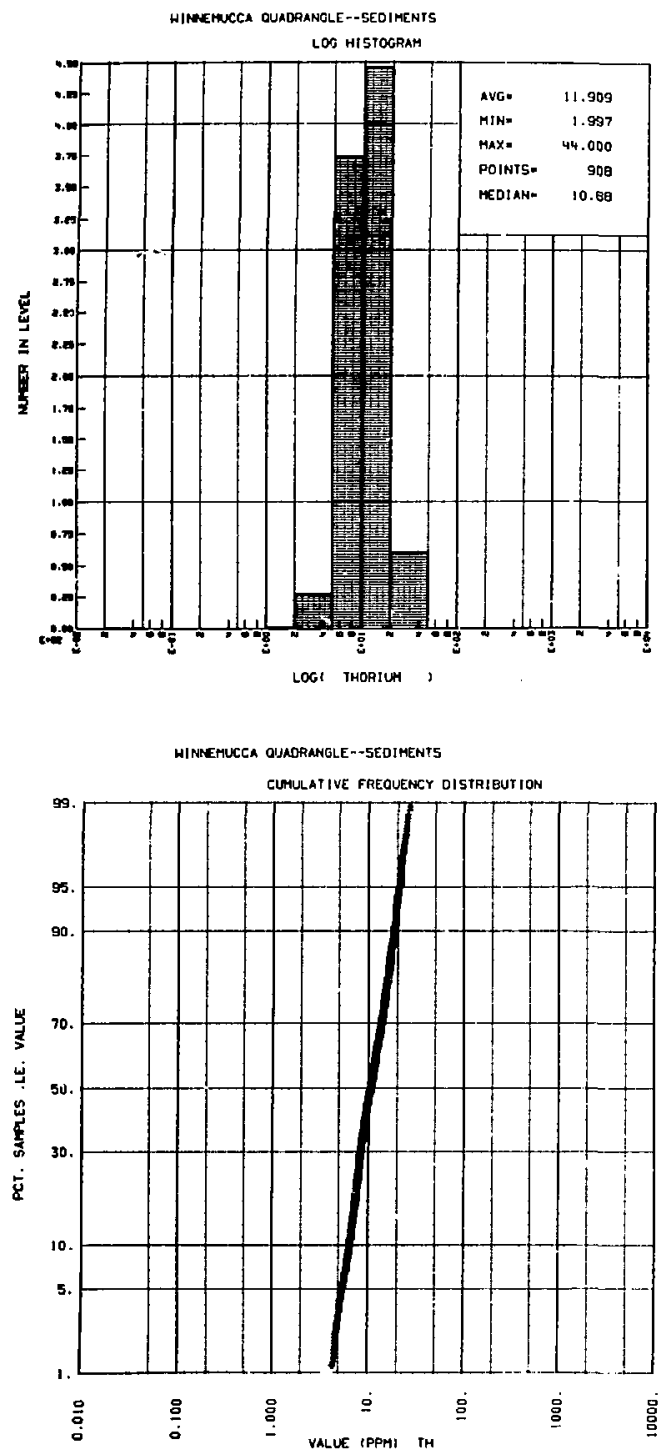

Fig. A-5. Histogram (a) and cumulative frequency xistribution (b) of sediment samples plotted on overlay $2 \mathrm{C}$. 


\section{DATA DEFINITIONS}

This section presents a brief explanation of the columnar entries for the hardcopy and microfiche data tables.

Blaniss in the data tables indicate not reported, generally below detection limits. In the case of neutron activation the detection limit is a function of sample composition. Undetected values are therefore not necessarily less than the smallest real values reported.

\section{DOE Sample Number}

Each analyzed field sample is assigned an DOE sample number consisting of 28 characters (five characters) (dashes) are used to delineate the number subdivision). The subdivision assignments are as follows:

\begin{tabular}{|c|c|c|}
\hline Position & & escription \\
\hline $1-2$ & ST, & $\begin{array}{l}\text { State, The two-digit Federal Informatio. Processing } \\
\text { Standard (FIPS) designated for the state corresponding to } \\
\text { the sample site location (AZ=04, } C A=06, I D=16, N V=32 \text {, } \\
O R=41, U T=49, W A=53 \text { ). }\end{array}$ \\
\hline $4-10$ & LAT, & Latitude of site in decimal degrees. \\
\hline $12-19$ & LONG, & Longitude of site in decimal degrees. \\
\hline 21 & $\mathrm{~L}$, & Originating laboratory $(1=L L L)$ \\
\hline $23-24$ & $\mathbf{T Y}$ & $\begin{array}{l}\text { DOE Sample Type. A two-digit code describing the sample } \\
\text { source, medium, and overall geochemical treatment (field } \\
\text { and laboratory) prior to analysis. See DOE Sample Type } \\
\text { Numbers below for specific assignments. }\end{array}$ \\
\hline $26-28$ & RPL, & $\begin{array}{l}\text { Replication Code. A three-digit code to distinguish } \\
\text { between samples of the same type taken from the same sit }\end{array}$ \\
\hline
\end{tabular}

TY, DOE Sample Type Numbers

Number

01

02

03
Description

Spring water sample untreated.

River or stream water sample untreated.

Well water sample untreated. 
04

06

07

ט8

09

21

Lake or reservoir water sample untreated.

Spring water sample filtered through a $0.45 \mu \mathrm{m}$ membrane filter and acidified to a pH of $\leq 1$ with high purity nitric acid ( $\mathrm{HNO}_{3}$ ).

River or stream water sample filtered through a $0.45 \mu \mathrm{m}$ membrane filter and acidified to a pH of $\leq l$ with high purity nitric acid ( $\mathrm{HNO}_{3}$ ).

Well water sample filtered through a $0.45 \mathrm{\mu m}$ membrane Eilter and acidified to a $\mathrm{pH}$ of $\leq 1$ with high purity nitric acid (HNO ${ }_{3}$ ).

Lake or reservoir water sample filtered through a 0.45 $\mu \mathrm{m}$ membrane filter and acidified to a pH of $\leq 1 \mathrm{with}$ high purity nitric acid ( $\mathrm{HNO}_{3}$ ).

Spring water sample filtered through a $0.45 \mu \mathrm{m}$ membrane filter.

River or stream water sample filtered through a $0.45 \mu \mathrm{m}$ nembrane filter.

Well water sample filtered through a $0.45 \mu \mathrm{m}$ membrane filter.

Lake or reservoir water sample filtered through a 0.45 um membrane filter.

Wet sediment sample dried at $110^{\circ} \mathrm{C}$ and sieved to the reported particle size range.

Lake or reservoir sediment sample dried at $110^{\circ} \mathrm{C}$ and sieved to the reported particle size range.

Dry sediment sample dried at $110^{\circ} \mathrm{C}$ and sieved to the reported particle size range.

playa sediment sample taken by hand auger over the reported depth, dried at $100^{\circ} \mathrm{C}$, and crushed to a fine powder.

Rock sample crushed and sieved to less than $259 \mu \mathrm{m}$.

\section{TEMP}

Temperature. Measurement of water temperature in situ by mercury thermometer to nearest $0.1^{\circ} \mathrm{C}$. 
Acidity in $\mathrm{pH}$ units, reported to nearest $0.1 \mathrm{ph}$ unit at ambient water temperature.

\section{SP COND}

Specific conductance. Measurement in situ with a commercial conductivity meter. Reported as conductance in micromhos per $\mathrm{cm}$ ( $\mu \mathrm{mho} / \mathrm{cm})$ normaiized to $25^{\circ} \mathrm{C}$.

\section{PHENO-AI.K}

Phenolphthalein alkalinity. Neasurement by titration with standard sulphuric acid to a phenolphthəlein indicator endpoint (pH $=8.3$ ). Reported as an equivalent amount of $\mathrm{CaCO}_{3}$ in $\mathrm{mg} / 1$, minimum detection $20 \mathrm{mg} / 1$.

\section{TO'T-AI.K}

Total alkalinity. Measurement by titration with standard sulphuric acid to a bromeresol green-methyl red indicator endpoint ( $\mathrm{pH}=4.8$ ). Reported as an equivalent amount of $\mathrm{CaCO}_{3}$ in $\mathrm{mg} / 1$, minimum detection $20 \mathrm{mg} / 1$.

\section{Possible Contamination}

The major possible contaminant types are indicated according to the following code: 1. none, 2, mining, 3. agricultural, 4. industrial, 5. sewage, 6. power generation, 7. urban, B. recreation, 9. other.

\section{URANIUM}

The trace element concentration of uranium in the sample is given in parts-per-billion (PPB) by weight for waters and in parts-per-million (PPA) by weight for sediments and rocks. Tine error column (ERR) gives a numerical estimate (expressed in trace element cor entration units) of the uncertainties associated with quantization of the gama-ray spectrum. 


\section{APPENDIX B}

NUMERICAL RESULTS OF RECONNAISSANCE SURVEY 
SITE TABLE

THERIUMINAAI
TPM

NATBER ST LAT LANG L IY RPL MO-DA-YR SOURCE, COND. UPPER LOHER CONT

Q. C. URANIUHIONE
D-REF

$3.66 \quad 002^{-25} 7.02$

5074 32-40.5134-116.1218-1-72-100 63/07/76 STREAM ORY 1000

$507532-40.5261-116.1335-1-72-10009 / 07 / 76$ STREAM

$507732-40.5393-116.0967-1-72-10008 / 07 / 75$ STREAM

$507832-40.5404-116.1238-1-70-100$ 08/07/76 STREAH

$507932-40.5667-116.1412-1-70-100$

5000 3e-40.5784-116. $3481-1-72-100$ 08/07/76 STAEAM

5081 32-40.5946-116.136/-1-70-100 08/07/76 STREAM

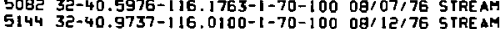

$514532-40.9476-116.0092-1-70-10008 / 12176$ STREAH

$5 / 4832-40.8953-116.0028-1-72-100$ 08/12/76 STREAM

$514932-40.8530-116.0058-1-70-10008 / 12 / 75$ STREAM

5149 3e-40.8530-116.0058-1-70-101

$515132-40.0140-116.0479-1-72-1000$

5152 32-40.8146-116.0479-1-7e-100 D8 IET T6 STREAM

$515332-40.9339-116.0906-1-72-100$ 08/1236 STREAM

5154 32-40 $9366-116.0974-1-72-10008 / 12 / 76$ STREAM

$515532-40.7186-115.0919-1-70-100$ 08/13/75 SIREA

5156 32-40 7283-116 0764-1-72-100 08/13/75 SIREAM

5157 32-40.7660-116.0521-1-72-100 08/13/75 5TREAH

$515832-40.7595-116.0309-1-72-100$ 08/13/76 5IREAM

$515932-40.7298-116.0373-1-72-10008 / 13 / 76$ 5TREAM

$515932-40.7290-116.0373-1-72-101$ STREAM

$516032-40.7269-116.0101-70-10008 / 13 / 76$ STREAH

$539632-40.6 ! 481-116.1312-1-70-10008 / 27 / 76$ STREAH

$539732-40.6908-116.1171-1-70-10008 / 27 / 76$ SIREAM

$539832-40.6564=: 16.0951-1-70-10 \% 08 / 27 / 76$ STREAM

5399 32-40.4377-116.0520-1-70-100 08/27/76 STREAM

$539932-40.4677-116.0620-1-70-101$
$542332-40.6349-116.0032-1-72-100$
$50 / 29 / 75$ 5TREAM

$542332-40.6349-116.0032-1-72-10000 / 29 / 76$ STREAM

$542432-40.6674-116.0074-1-72-10000 / 29 / 76$ 5IREAM

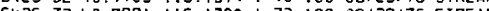

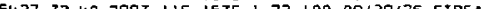

$5470.40 .7963-15.1535-1-750-100$ 08

$542932-40.7986-116.1999-1-72-100$ 0月/29/76 STREAM

$542932-40.7986-116.1999-1-72-101$ STREAM

5430 32-40.8276-116.2268-1-72-100 00/29/76 5TREAM

$543132-40.8429-116.2230-1-70-10008 / 29 / 75$ SIREAM

$543332-40.8249-116.2221-1-70-10008 / 30 / 76$ STREAM

$543432-40.9286-1,5.2375-1-72-10008 / 30 / 76$ STREAM

$543532-40.9412-15.2290-1-70-10000 / 30 / 75$ STREAM

5440 32-40.8430- .

$544132-40.8647-116.2302-1-70-10000 / 30 / 76$ STREAM

$544232-40.8188-1 i 6.2518-1-i 3-10008 / 30 / 76$ STREAM

\begin{tabular}{|c|c|c|}
\hline ORY & 1000 & 0500 \\
\hline DRY & 1000 & 9500 \\
\hline WE T & 1000 & 0500 \\
\hline DRY & 1000 & 0500 \\
\hline WET & 1000 & 0500 \\
\hline HET & 1000 & 0500 \\
\hline DRY & 1000 & 0500 \\
\hline HET & 1000 & 0500 \\
\hline WE $\dagger$ & 1000 & 0500 \\
\hline WET & 1000 & 0500 \\
\hline WE: & 1000 & 0500 \\
\hline DRY & 1000 & 0500 \\
\hline HE T & 1000 & 0500 \\
\hline HET & 1000 & 0500 \\
\hline WE T & 1000 & 0500 \\
\hline $\begin{array}{l}\text { DRY } \\
\text { DRY }\end{array}$ & $\begin{array}{l}1000 \\
1000\end{array}$ & $\begin{array}{l}0500 \\
0500\end{array}$ \\
\hline DRY & 1000 & CSOC \\
\hline DRY & 1000 & 0500 \\
\hline WE 1 & 1000 & 0500 \\
\hline CRY & 1000 & 0500 \\
\hline DRY & 1000 & 0500 \\
\hline GRY & 1000 & 0500 \\
\hline CRY & iono & 0500 \\
\hline DRY & 1000 & 0500 \\
\hline HE $T$ & 1000 & 0500 \\
\hline WET & 1000 & 0500 \\
\hline HE 1 & 1000 & 0500 \\
\hline WEI & 1000 & 0500 \\
\hline WET & 1000 & 0500 \\
\hline HET & 1000 & 0500 \\
\hline ORY & 1000 & 0500 \\
\hline ORY & 1000 & 0500 \\
\hline HE I & 1000 & 0500 \\
\hline ORY & 1000 & 0500 \\
\hline DRY & 1000 & 0518 \\
\hline$H E r$ & 1000 & 0500 \\
\hline DRY & 1000 & $050 \mathrm{C}$ \\
\hline DRY & 1000 & $050 \mathrm{C}$ \\
\hline DRY & $: 000$ & $050 \mathrm{C}$ \\
\hline HEI & 1000 & 0500 \\
\hline WE: & 1000 & 0500 \\
\hline DFY & 1000 & 0500 \\
\hline ORY & 1000 & 0500 \\
\hline We $t$ & 1000 & 0500 \\
\hline ERr & 1000 & 0503 \\
\hline WC! & 1000 & OSOO \\
\hline HE? & 1000 & 0500 \\
\hline WE I & $1000^{\circ}$ & 0500 \\
\hline
\end{tabular}

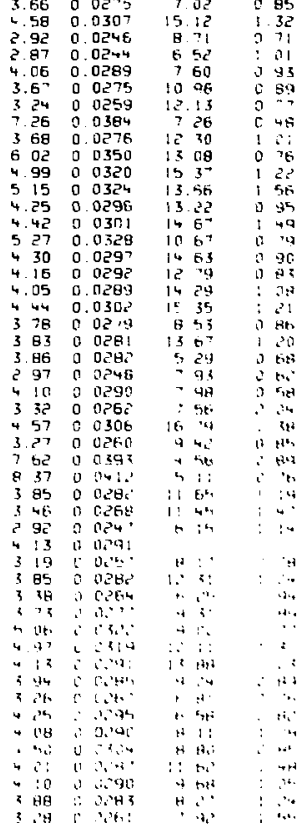


SITE LAT. MPLE NUMBER-.-- DATE PARTICLE SITE POS Q. LEF DAAIUMIIINC I
FPH WHEHIUMINAA, FNH

$544432-40.8990-116.1334-1-70-100$ 06/30/76 STREAM

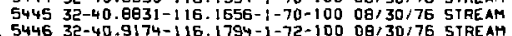

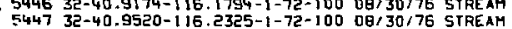
$344832-40.9660-116.1693-1-72-10000 / 30 / 76$ SIREAM $544932-40.9587-116.1635-1-70-10000 / 30 / 76$ STREAM 5449 32-40.9587-116.1635-1-70-101 57REAM 5451 32-40.7550-116.4150-1-72-100 09/04/76 STREAM $545332-40.7900-116.3990-1-72-10009104176$ STREAM $545432-40.7546-116.3915-1-72-100$ 09/04/76 STEAM $545532-40.7529-116.3840-1-72-10009 / 04 / 76$ SIREAM $545632+40.7906-116.3540-1-70-10009 / 04.75$ STREAM $545732-40.7895-136.3232-1-70-100$ 09/04/76 STREAM 5458 32-40.7923-116.3327-1-72-100 09/04/76 STREAH $545932-40.6192-116.3206-1-72-10009 / 04 / 76$ 5IREAM $545932-40.8192-\$ 16.3206-1-72-101$ STREAM $546032-40.8551-116.2917-1-72-100$ 09/04/76 STREAM 5461 32-40.8586-116.2703-1-72-100 09/04/76 STREAM $546232-40.8591-166.3664-1-72-10009 / 04 / 76$ STREAM 5463 32-40.8075-116.4985-1-7e-100 09/04/76 STREAM $546432-40.6516-116.4946-1-72 \overrightarrow{-}-100$ 09/04/76 STREAM $546532-40.8021-116.4469-1-72-100$ 09/04/76 STREAM 5467 32-40.9097-116.3900-1-72-100 09/04/76 STREAM 5467 32-40.9017-116.4076-1-70-100 09/04/76 STREAM 5469 32-40.901 5469 32-40.0925-115.2300-1-72-101 $547132-40.9745-116.2390-1-72-100$ 09/04/75 STREAM 5472 32-40.9831-116.3092-1-70-100 09/04/76 STREAH 5473 32-40.9987-115.3402-1-70-100 09/04/76 STREAM 5474 32-40.9952-116.3805-1-72-100 09/C4/76 STREAM 5475 32- 40 . 9827-116.4033-1-70-100 09/04/76 STREAH 5475 32-40.9873-1/16/4058-1-72-100 09/04/76 STREAM 5477 32-40. $3838-116.4282-1-78-108$ 09/04/76 STREAH 作 $547932-40.8896-116.4979-1-72-10009 / 05 / 76$ SIREAT 5479 32-40.8886-116.4979-1-72-101 $549032-40.9425-116.4679-\{-72-100$ 09/05/76 STREAH $548132-40.9615-116.4843-1-72-10009 / 05 / 76$ 5IREAM $548232-40.9605-116.4558-1-72-100$
5493 5493 32-40.9703-116.4485-1-72-100 09/05/76 STREAM $552232-40.9472-116.0757-1-70-100$ 09/07,76 STREAH 5523 32-40.9835-116. I673-1;0-100 09/07/76 STREAM $552432-40.9076-116$ 0798-1-72-100 09/07/75 5IREAM $552532-40.9006-116$ 1072-1-72-100 09/07/76 STREAM $552632-40.9251-115.1235-1-72-10009 / 07 / 76$ STREAH $553132-40.7152-116.0091-1-70-10009 / 08 / 76$ 5TREAM

\begin{tabular}{|c|c|c|}
\hline HE 1 & 1000 & 0500 \\
\hline $\begin{array}{l}\text { WET } \\
\text { DRY }\end{array}$ & $\begin{array}{l}1000 \\
1000\end{array}$ & $\begin{array}{l}0500 \\
0500\end{array}$ \\
\hline OFY & 1000 & 0500 \\
\hline ORY & 1000 & 0500 \\
\hline WE! & 1000 & 0500 \\
\hline HET & 1000 & 0500 \\
\hline HE T & 1000 & 0500 \\
\hline DRY & 1000 & 0500 \\
\hline DRY & 1000 & 0500 \\
\hline DAY & 1000 & 0500 \\
\hline DRY & 1000 & 0500 \\
\hline HET & 1000 & 0500 \\
\hline WE T & 1000 & 0500 \\
\hline DFY & 1000 & 0500 \\
\hline ORY & 1000 & n50o \\
\hline ORY & 1000 & 0500 \\
\hline DRY & 1000 & 0500 \\
\hline GRY & 1000 & 0500 \\
\hline DRY & 1000 & 0500 \\
\hline DRY & 1000 & 0500 \\
\hline $\begin{array}{l}\text { ORY } \\
\text { ORYY }\end{array}$ & 1000 & 0500 \\
\hline ORY & 1000 & 0500 \\
\hline ORY & $100 n$ & 0500 \\
\hline $\begin{array}{l}\text { HE T } \\
D R Y\end{array}$ & 1000 & 0500 \\
\hline $\begin{array}{l}\text { DRY } \\
\text { DRY }\end{array}$ & 1000 & 0500 \\
\hline $\begin{array}{l}\text { DRY } \\
\text { ORY }\end{array}$ & $\begin{array}{l}1000 \\
1000\end{array}$ & $\begin{array}{l}0500 \\
0500\end{array}$ \\
\hline DRY & 1000 & 0500 \\
\hline WE T & 1000 & 0500 \\
\hline HE 1 & 1000 & 0500 \\
\hline DRY & 1000 & 0500 \\
\hline $\begin{array}{l}\text { WET } \\
\text { DRY }\end{array}$ & 1000 & $\begin{array}{l}0500 \\
0500\end{array}$ \\
\hline HET & 1000 & 0500 \\
\hline DRY & 1000 & 0500 \\
\hline ORY & 1000 & 0500 \\
\hline DRY & 1000 & 0500 \\
\hline DRY & 1000 & 0500 \\
\hline DRY & 1000 & 0500 \\
\hline DRY & 1000 & 0500 \\
\hline DRY & 1000 & 0500 \\
\hline ORY & 1000 & 0500 \\
\hline WET & 1000 & 0500 \\
\hline WE T & 1000 & 0500 \\
\hline DRY & 1000 & 0500 \\
\hline DRY & 1000 & 0500 \\
\hline DRY & 1000 & 0 \\
\hline WE I & 1000 & 0500 \\
\hline
\end{tabular}

\begin{tabular}{|c|c|c|c|c|c|}
\hline 0 & $0 \quad 0289$ & is & $\because$ & & 15 \\
\hline 59 & 0.0306 & 11 & $L^{\prime} r^{\prime}$ & : & 'וF \\
\hline 348 & 0 0.568 & 5 & $1^{\prime}$ & 0 & \\
\hline 381 & $0 \quad 0290$ & 6 & 34 & 0 & in \\
\hline 375 & $0 \quad 0279$ & a & E: & 1 & $0 r^{\prime}$ \\
\hline 598 & $\begin{array}{ll}0 & 0 \\
0 & 4+9\end{array}$ & 7 & 54 & 1 & is: \\
\hline 99 & 0. 0249 & 6 & 98 & 0 & $\mathrm{H}_{4}$ \\
\hline 95 & $0 \quad 02^{4}+8$ & 3 & 9h & ; & BO \\
\hline 55 & 0.0505 & $1 \%$ & 48 & 1 & sis \\
\hline 34 & 0.0299 & A & HB & 9 & ตี \\
\hline 24 & 0.0323 & b & (8) & $i$ & $\mathbf{x}^{\prime}$ \\
\hline 05 & 00351 & 9 & 96 & $\mathbf{0}$ & $4:$ \\
\hline 6.7 & 0.0309 & H & 43 & n & HI: \\
\hline 57 & $0 \quad 0306$ & 1 & 41 & 1 & $3 z$ \\
\hline 91 & $0[2347$ & 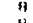 & $7 \mathrm{~h}$ & 13 & He: \\
\hline 33 & $\begin{array}{ll}0 & 0298\end{array}$ & 8 & +4 & $\vdots$ & $\because 4$ \\
\hline 55 & 0.0299 & s & 4: & 1 & He: \\
\hline 18 & 0.0757 & 10 & J $r^{\prime}$ & $!$ & 14 \\
\hline 357 & 0.0?72 & 10 & 36 & : & 1 \\
\hline 3.86 & 00282 & $1 c^{2}$ & 40 & 1 & 11 \\
\hline 39 & 0.0.977 & 18 & 64 & i & $r i_{1}$ \\
\hline 46 & 0.0227 & 5 & 04 & $n$ & in \\
\hline 1: & 60323 & 20 & 19 & $i^{\prime}$ & His \\
\hline 545 & 00334 & 14 & 74 & 1 & $3 \mathrm{t}_{2}$ \\
\hline 4.88 & 00315 & 10 & 40 & 1 & 33 \\
\hline $\begin{array}{ll}3 & 69 \\
7 & 30\end{array}$ & $\begin{array}{l}0.0275 \\
0.0385\end{array}$ & & 95 & , & $0^{\circ}$ \\
\hline 93 & $0.03 \div a$ & & & & \\
\hline .02 & 0.0 व日a & 7 & $5 r^{\prime}$ & 0 & $\theta 0$ \\
\hline $\begin{array}{l}480 \\
428\end{array}$ & $\begin{array}{l}0.03114 \\
0.0296\end{array}$ & &,$x$ & 1 & \\
\hline .77 & 0.0313 & & .38 & $r^{2}$ & $3 \mathrm{~B}$ \\
\hline 62 & 0.0234 & 8 & 37 & 0 & $\because 1$ \\
\hline 03 & 0.0251 & 5 & ह7 & 0 & GF, \\
\hline 54 & 0.0230 & 4 & 31 & 0 & 5 \\
\hline $\begin{array}{l}85 \\
89\end{array}$ & $\begin{array}{l}0.0315 \\
0.0245\end{array}$ & ? & 65 & 0 & \\
\hline 68 & 0.023 ? & 14 & & 6 & 1า \\
\hline 59 & $0 \quad 0307$ & 17 & 93 & $i$ & 41 \\
\hline 99 & 40320 & 16 & $5 !$ & 1 & $i \cdot \cdot$ \\
\hline & 0.0279 & $\mid \vec{\imath}$ & $9 H$ & 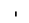 & 74 \\
\hline 73 & 86278 & 14 & 17 & ! & \\
\hline 49 & c 0364 & 10 & 6 & 1 & $\therefore 4$ \\
\hline 65 & $0 \quad 0304$ & Is & 31 & ! & 37 \\
\hline & 0 029i, & $1^{\circ}$ & 0 & $i$ & $4 i$ \\
\hline & $\begin{array}{lll}0 & 0311,2\end{array}$ & & & & \\
\hline 48 & 003.15 & 14 & $1+$ & $!$ & $: 6$ \\
\hline & $0 \quad 024$ & i1 & $F_{13}$ & $i$ & 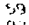 \\
\hline & ח & & 24 & - & 'It' \\
\hline
\end{tabular}


SIT

THORIUMINAAI
PPH ERR

NIMBER ST LAT. SAMPLE NUMEER--- DATE SAMPLE PARTICLE SIZE PSS

a. C. URANIUH(ONC)

$553832-40.7282-116.1711-1-72-100$ 09/00/76 STREAH

ORY 1000

ORY 1000

源

STREAH

$554032-40.6924-116.1918-1-72-10009 / 99 / 76$ STREAH

$554232-40.6267-116.0979-1-72-10009 / 09 / 76$ STREAM

$554332-40.5646-116.2258-1-70-100$ 09/09/76 STREAM

5544 32-40.5805-116.1705-1-70-100 09/09/76 STREAH

$554532-40.6103-116.1986-1-70-100$ 09/09/76 STREAM

$554632-40.6223-116.2327-1-72-10009 / 09 / 76$ STREAM

554 32-40.6506-116.1495-1-72-100 09/09/76 STREAH

5549 3e-40.9085-11?.4844-1-72-100 09/11776 STREAH

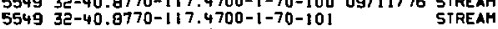

$555032-40.9955-117.7264-1-70-100$ 09/11/76 STREAM

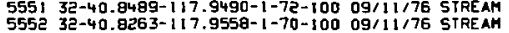

$555332-40.8028-117.9626-1-72-100$ 09/11176 STREAH

作 $35-40.7793-117.9753-1-70-100$ 09/11/76 STREAH

555 32-40.8541-117.8471-1-72-100 09/1176 SIREAM

$555732-40.9784-117.8570-1-72-100$ 09/11/76 STREAH

$555832-40.9979-117.8941-1-72-100$ 09/11/76 STREAH

$555932-40.9763-117.8998-1-72-100$ 09/11/76 5TREAH

559 32-40.9763-117.9998-1-72-101 STREAH

$556132-40.9774-1179818-1-72-100$ 09/11/75 SIREAH

$556232-40.9789-117,7833-1-72-100$ 09/12/75 SIREAM

5563 32-40.9905-1]7.8050-1-72-100 09/12/76 SIREAH

5564 32-40.8066-117.4956-1-72-100 09/12/76 SIREAH

$556532-40.8074-117.5193-1-72-100$ 09/12/76 STREAM

$556632-40.8310-117.4910-1-72-10009 / 12 / 76$ STREAH

$556832-40.8552-117.5256-1-70-100$ 09/12/76 STREAM

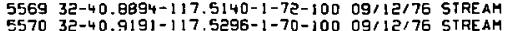

$557132-40.9271-117.5535-1-72-100$ 09/12/76 STREAM

$557232-40.9469-117.5465-1-75-100$ 09/12,75 STREAM

5573 32-40 5523-1175667-1-70-100 09/12/76 STREAM $557432-40.9 \% 11-117.5800-1-72-100$ 09/12/76 STREAM 源 5576 32-40.9825-117.5431-1-72-100 09/03/76 SIREAH 5578 32-40.9420-117.6408-1-70-100 09/13/76 5IREAM $557932-40.9158-117.6496-1-72-100$ 09/13/76 STREAM $557932-40.9158-117-6496-1-72-101$ STREAM $558032-40.9176-1: 7.6436-1-70-100$ 09/13/76 STREAM $558,32-40.9020-117.6969-1-70-100$ 09/13/76 STREAH $558232-40.8030-1 / 2.7157-1-72-10009 / 13,76$ STREAM

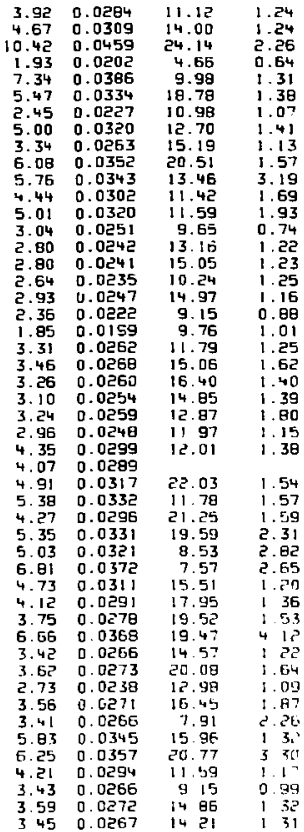


SITE - DOE SAMPLE NUMBER---- DATE SAMPLE PARTICLE SIZE POS.
NUMEER ST LAT. LONG. L IY RPL HO-OA-YR SOURCE/COND. UPPER LOWER CONT

$$
\text { a. C. } \underset{X-R E F}{ }
$$

$558432-40.8127-117.7126-1-70-100$ 09/13/76 STREAH HEI 1000 0500 5596 3e-40.7302-117.6596-1-70-100 09/13/76 STREAM 5587 32-40.9040-117.92es- $-70-100$ 09, 3 7 76 STREAM 5 $558932-40.8570-17.9291-1-72-10009 / 13 / 76$ STREAH $559032.117 .9510-1-72-100$ 09/13/76 STREAH $559132-40.7677-117.8436-1-72-10009 / 13175$ STREAH $559232-40.0925-1174498-1-72-10009 / 13175$ SIREAM $559332-40.9810-137.3507-1-72-10009 / 13 / 76$ SIREAM $559432-40.9920-117.3162-1-70-100$ 09/14/76 STREAH: 5595 32-40.9325-117.3171-1-72-100 09/13/76 SIREAM 5596 32-40.9352-1.7.3172-1-72-100 09/13/76 SIREAH 5597 32-40.9115-117.4013-1-72-100 n9/14/76 STREAH 5598 32-48.8747-117.3667-1-72-100 09/05/76 5TREAM 5599 32-40.8936-117.3834-1-72-100 09/14/76 STREAH $560032-40.8685-117.3299-1-72-10009 / 14 / 76$ STREAH $585932-40.60\}-117.9502-1-70-10009 / 19 / 76$ STREAM 6101 32-40.7401-117.9502-1-70-100 09/19176 STREAM $610232-40.7327-117.9426-1-72-10009 / 14 / 76$ STREAM 6103 32-40.7361-117.9675-1-72-100 09/14/76 STREAM $610532-40.6739-117.9625-1-72-10009 / 14176$ SIREAH 6107 32-40.6980-117.8B2-1-72-100 09/1475 STREAH $610832-40.7054-117.8506-1-72-10009 / 14 / 76$ STREAH $610932-40.7242-117.8766-1-72-10009 / 14176$ SIREAM $611132-40.5948-117.9537-1-72-100$ STREAH $611232-40.5514-117.9700-1-72-10009 / 16 / 76$ STREAM $611332-40.5136-117.9691-1-72-100$ 09/16/76 STREAM $611432-40.5198-117.3751-1-72-100$ 09/16/76 5TREAM $611532-40.7317-117.0361-1-72=10009 / 17 / 76$ SIREAM $611632-40.7065-117.8285-1-72-10009 / 17 / 76$ STREAM $611732-40.6715-117.8116-1-72-10009 / 17 / 76$ STREAM $611832-40.6482-117.7948-1-72-10009 / 17 / 76$ SIREAM $611932-40.6246-117.8277-1-72-10009 / 1776$ SIREAM $611932-40.6246-117.6217-1-72-10109017 / 76$ STREAM 61 $32-40.5966-117.8165-1-72-10009 / 17176$ STREAM 6122 32-40.5654-117.7515-1-72-100 09/17176 5TREAH 61 $332-40.5483-117.7889-1-72-10009 / 17176$ STREAM $612432-40.5389-117.8431-1-72-100$ 09/17/76 STREAH $615432-40.0036-117.3210-1-72-100$ 09/20/76 STREAM $620132-47.1568-116.4329-1-72-10008 / 01 / 76$ STREAH $620232-40.1225-115.4261-1-72-10008 / 01 / 76$ STREAM $620332-40.1074-116.4814-1-72-10000 / 01 / 76$ STREAM $620432-40.1479-116.4682-1-72-100$ 08/01/76 SIREA $620532-40.1705-116.4833-1-72-10000 / 01 / 76$ STREAM
$620632-40.1795-116.4761-1-72-10000 / 01 / 76$ STREAH

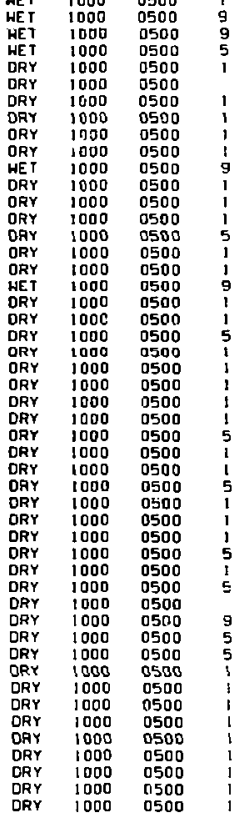

THOR ! UM I NAA I

URANIUMIONCI PPH ERR

3.7) 0.0277 $19.34 \quad 1.38$ $\begin{array}{lll}3.46 & 0.0257 & 11.40 \\ 3 & 1.07\end{array}$

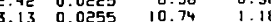
$\begin{array}{llll}3.84 & 0.0243 & 10.58 & 1.23\end{array}$ $\begin{array}{llll}3.47 & 0.0268 & 18.09 & 1.53\end{array}$ $\begin{array}{ll}3.82 & 0.0273 \\ 4.50 & 0.0304\end{array}$ $\begin{array}{lll}3.40 & 0.0534\end{array}$ 5.88 0.0245 $6.24 \quad 0.0356$ $5.40 \quad 0.0332$ $1.78 \quad 0.0195$ 1.79
1.90
1.0219 1.9000 .0231 $\begin{array}{ll}2.58 & 0.0237 \\ 2.55 & 0.0231\end{array}$ $\begin{array}{ll}5.55 & 0.0231 \\ 5.43 & 0.0333\end{array}$ $\begin{array}{ll}5.43 & 0.0333 \\ 3.26 & 0.0260\end{array}$ 4.7 .30 .0311 3.15 0.0250 3.060 .0252 $\begin{array}{ll}\text { 2.91 } & 0.0246 \\ 5.67 & 0.0340\end{array}$ 6.20 0.0355 4.510 .0304 2.91 0.0246 2.72 $0.023 \theta$

1.980 .0205

2. 050.0208

3.480 .0368

$2.05 \quad 0.0244$

$\begin{array}{ll}3.73 & 0.0277 \\ 3.33 & 0.0262\end{array}$ $\begin{array}{ll}3.33 & 0.0262 \\ 3.48 & 0.0268\end{array}$ $\begin{array}{ll}3.48 & 0.0268 \\ 3.16 & 0.0256\end{array}$ 3.400 .0265 1.81 0.0196 3.120 .0254 ट.71 0.6238 $3.66 \quad 0.0202$ 4.09 0.0290 3.920 .0284 $3.98 \quad 0.0286$ 3.78 0.0279 $\begin{array}{rl}3.03 & 0.0243 \\ -56 & 0.0271\end{array}$ $\begin{array}{ll}18.75 & .53 \\ 20.52 & 1.51\end{array}$

\begin{tabular}{l}
$8.49 \quad 1.29$ \\
\hline .29
\end{tabular}

a.20 1.13

9.07 0.95

$\begin{array}{ll}5.49 & 1.57\end{array}$

11.51

$\begin{array}{rl}11.81 & 1.34 \\ 5.52 & 5.25\end{array}$ 22.75 1.76 $\begin{array}{rl}14.40 & 1.22 \\ 5.15 & 0.62\end{array}$

$7.57 \quad 1.6$

7.59
13.53
1351.59

$1350 \quad 1.27$

14.22, 5

9.61 .09

9.75

$1.08 \quad 1.25$

$8.85 \quad 1.25$

9.20 1.59

$11.20 \quad 1.67$

$\begin{array}{ll}2.62 & 1.36 \\ 9.57 & 2.87\end{array}$

8. $84 \quad 1.11$ 
$620732-40.2029-116.4689-1-72-10008 / 01 / 76$ STREAM
$620032-40$. $3990-116.4032-1-72-10008 / 01 / 76$ STREAM 6269 32-40.1628-116.3780-1-72-100 08/01/76 STREAM $621032-40.1951-116.3491-1-72-10008 / 01 / 76$ STREAH 6e c $32-40.2310-116.3405-1-72-100$ 0B 01176 STREAM $621432-40.2316-116.2794-1-72-100$ STREAM 6216 32-40.3638-116.6208-1-72-100 00/02/76 STREAM $621732-40.3980-116.5970-1-72-10008 / 02 / 76$ STREAM $621632-40.4277-116.5898-1-72-10008 / 02 / 76$ STREAM E219 32-40.4187-116.5945-1-72-100 08/02/76 5TREAM $621932-40.4167-116.5945-1-72-1010$

$622032-40.4610-115.5695-1-72-100$ 08:02/76 STREAM 6टट1 32-40.4951-116.5457-1-72-100 08/02/76 STREAM $622232-40.3279-116 \cdot 4279-1-70-10008 / 03 / 76$ STREAM 623 32-40.3805-116.3167-1-72-100 08/03776 STREAM 32-40.4615-16. $622632-40.4191-116.3057-1-72-100$ 08/03/76 STREAM

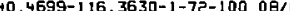
源 $622932-40.4573-116.3572-1-72-101$ STREAM . $623232-40.3902-116.6995-1-72-100$ 08/04/75 57R5AM 6233 32-40.4056-116.7513-1-72-100 08/04/76 STREAM $623432-40.3956-116.7042-1-72-10000 / 04 / 76$ 5 RREAM $623532-40.4503-116.6544-1-72-10008 / 04 / 76$ STREAM $623632-40,3667-116.6504-1-72-10008 / 05 / 76$ STREAH $623732-40.3812-116.7031-1-72-100$ 08/C5/76 STREAM $623832-40.38604-116.6844-1-72-10008 / 05 / 76$ STREAM $623932-40.0455-116.9660-1-72-10008 / 05 / 76$ STREAH $623932-40.6455-116.9660-1-72-101030$ SIREAM 624 32-40.0807-116.9918-1-70-100 08/05/76 STREAM 624 $32-40.0697-116.9601-1-72-10008 / 05 / 76$ STREAM $624332-40$. 1203-116.9225-1-72-100 09/05/76 STREAM $624432-40.1329-116.9073-1-72-100$ 00/05/76 STREAH $624532-40$. 1626-1I6.0791-1-72-100 08/05/76 STREAH 6246 3e-40.1995-116.8990-1-70-100 08/05/76 STREAM $624932-40.2022-116.9790-1-72-100$
$68 / 05 / 76$
STREAM 6250 32-40.1067-116.0390-1-72-100 08105/76 5TREAM $625132-40.1004-115.8301-1-72-100$ 0B/05/76 STREAM 6252 32-40.1274-115.8345-1-72-100 09/05/76 STREAM
Q. C. URANIUMIDNCI
X-REF PPH

5. $25 \quad 0.0238$

5.5) 0.0337

$4.99 \quad 0.0316$

$4.68 \quad 0.0 \geq 10$

0.0233
$.31 \quad 0.0216$

2.91 0.0246

$2.06 \quad 0.0208$

$\begin{array}{ll}3.17 & 0.0257\end{array}$

$\begin{array}{ll}3.00 & 0.0287 \\ 3.64 & 0.0274\end{array}$

3.51 D. 0269

4.130 .0291

$\begin{array}{ll}3.48 & 0.0268 \\ 2.61 & 0.0233\end{array}$

4.220 .0 .16

4.440 .0302

$6.45 \quad 0.0332$
$6.06 \quad 0.0351$

$.06 \quad 0.0351$

3.110 .0754

$4.15 \quad 0.0793$

$4.36 \quad 0.0299$

2.770 .0240

$2.07 \quad 0.0209$

$8.06 \quad 0.0404$

$10.08 \quad 0.0469$

$1.37 \quad 0.0172$

$3.77 \quad 0.0579$

$3.48 \quad 0.0268$

$\begin{array}{lll}5.39 & 0.0332\end{array}$

$4.58 \quad 0.0305$

$3.64 \quad 0.0274$

3.95 0.0त्र

4.010 .0297

4.990 .0323

3.500 .0269

$\begin{array}{ll}4.06 & 0.0289 \\ 1.05 & 0.0198\end{array}$

$3.33 \quad 0.0253$

$\begin{array}{lll}3.77 & 0.0279\end{array}$

$4.07 \quad 0.0289$

$2.92 \quad 0.0245$

$4.05 \quad 0.0315$ a.24 1.24

$\begin{array}{ll}11.60 & 1.05 \\ 11.03 & 0.97\end{array}$

1.73

$10.87 \quad 2.05$

$12.44 \quad 1.27$

$\begin{array}{rl}6.67 & 1.30 \\ 6.76\end{array}$

$\begin{array}{ll}11.85 & 1.25 \\ 11.14 & 1.37\end{array}$

1.00

16.25

$16.18 \quad 1.30$

$\begin{array}{ll}11.80 & 1.00\end{array}$

$22.62 \quad 1.70$

$18.67 \quad 1.48$

15.11 1.21

23.10 1.59

$19.17 \quad .13$

$12.63 \quad 1.15$

6.59
11.52

$\begin{array}{rl}31.90 & 1.20 \\ 31.35 & 0.625\end{array}$

$4.35 \quad 0.58$
4.750 .93

$\begin{array}{ll}8.76 & 0.93 \\ 5.13 & 0.77\end{array}$

$\begin{array}{ll}11.08 & 1.33 \\ 15.74 & 1.36\end{array}$

$15.90 \quad 1.48$

$1599 \quad 1.49$
998

19. $30 \quad 1.40$

$15.43 \quad 1.55$

$7.82 \quad 0.98$

$17.70 \quad 2.98$

5.22

$17.82 \quad 1.53$ 
SITE --DOE SAMPLE NUMBER-A.-. DATE SAMPLE PARTICLE $512 E$ POS.

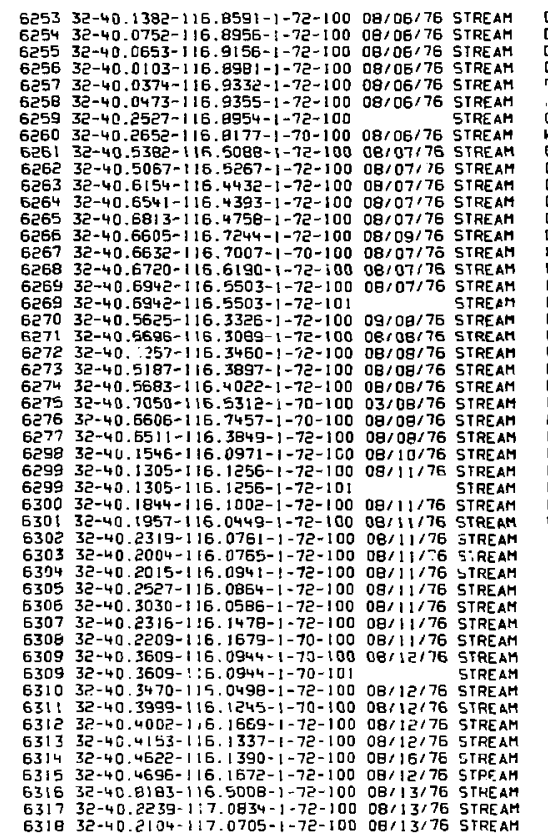

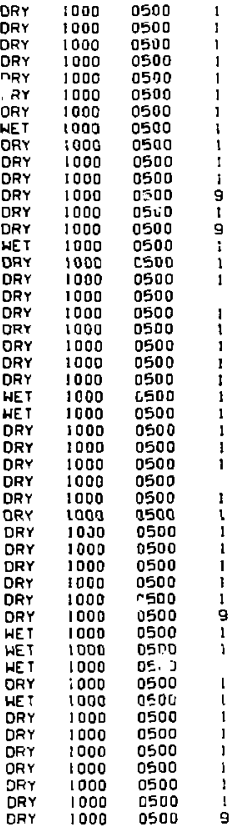

THORIUMINAA , $19.85 \quad 1.46$ $6.26 \quad 0.81$ $\begin{array}{rl}7.80 & 0.91 \\ 15.33 & 1.35\end{array}$

6.70 0.72

0.93 1.00

$\begin{array}{ll}15.25 & 1.57\end{array}$

$13.33 \quad 1.28$

8. $58 \quad 0.94$

6.32 1.68

$7.06 \quad 1.38$

10.95

10.70

$15.82 \quad 1.28$

9.47

$17.34 \quad 2.54$

15.85
9.25
11.89

11.250 .83

$32.04 \quad 1.16$

$10.45 \quad 0.96$

$9.80 \quad 1.18$

$9.40 \quad 1.08$
.40

$5.72 \quad 1.1$

$\begin{array}{ll}6.52 & 1.23\end{array}$

$9.84 \quad 1.35$

9.25 $\quad 1.95$

$\begin{array}{rl}9.25 & 1.95 \\ 12.12 & 1.14\end{array}$

$10.39 \quad 1.15$

\begin{tabular}{r|r}
8.62 \\
15.07
\end{tabular}

\begin{tabular}{l|l}
16.40 & 1.25 \\
20.23 & 1.57
\end{tabular}

$15.18 \quad 1.59$

$14.15 \quad 1.15$

$\begin{array}{rl}3.77 & 1.12 \\ 25.13 & 1.80\end{array}$ 


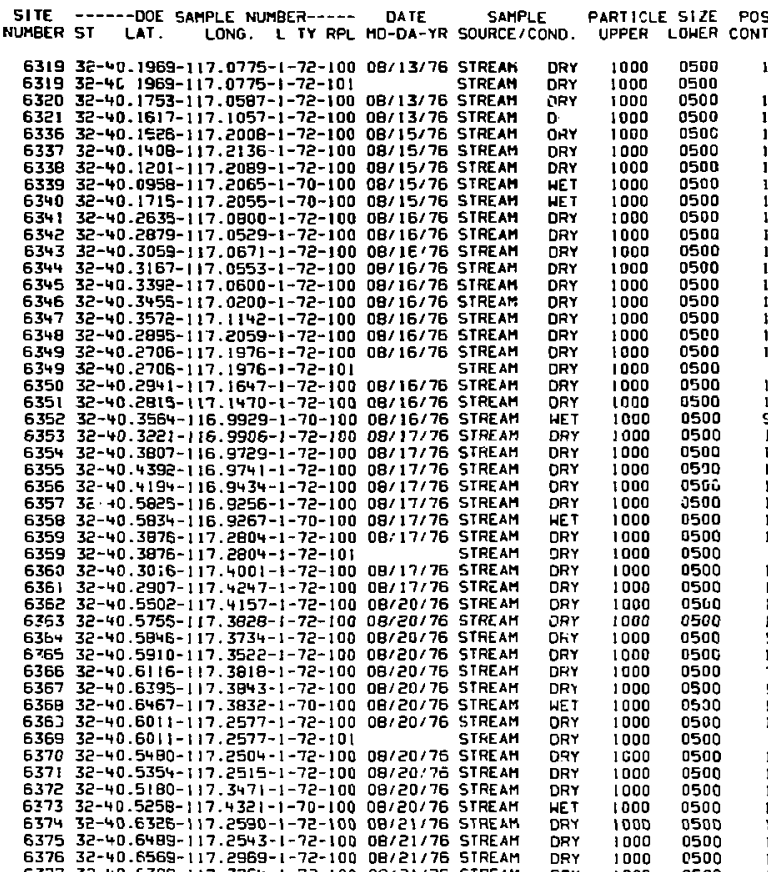

\begin{tabular}{|c|c|c|c|c|}
\hline \multirow[t]{2}{*}{$\begin{array}{l}\text { a. } c . \\
\text { X-RFF }\end{array}$} & \multicolumn{2}{|c|}{$\begin{array}{l}\text { URANIUH IDNC) } \\
\text { PPY ERR }\end{array}$} & \multicolumn{2}{|c|}{ THORIUHCNAAI } \\
\hline & $\begin{array}{l}1.84 \\
3.27 \\
4.46 \\
4.17 \\
7.19 \\
6.91 \\
7.22 \\
3.74 \\
5.27 \\
4.79 \\
4.53 \\
2.75 \\
1.99 \\
2.41 \\
3.15 \\
5.00 \\
1.69 \\
4.48 \\
4.68 \\
4.87 \\
5.54 \\
3.11 \\
2.84 \\
3.17 \\
3.12 \\
3.59 \\
7.13 \\
4.13 \\
3.39 \\
3.56 \\
9.91 \\
6.25 \\
2.96 \\
2.50 \\
3.43 \\
2.99 \\
2.40 \\
2.77 \\
2.85 \\
2.58 \\
2.56 \\
2.44 \\
3.23 \\
2.85 \\
2.84 \\
2.52 \\
2.22 \\
3.09 \\
2.25\end{array}$ & $\begin{array}{l}0.0198 \\
0.0260 \\
0.0303 \\
0.0293 \\
0.0392 \\
0.0375 \\
0.0383 \\
0.0279 \\
0.0328 \\
0.0313 \\
0.0305 \\
0.0239 \\
0.0205 \\
0.0225 \\
0.0256 \\
0.0320 \\
0.0190 \\
0.0303 \\
0.0310 \\
0.0316 \\
0.0336 \\
0.0254 \\
0.0243 \\
0.0256 \\
0.0254 \\
0.0272 \\
0.0391 \\
0.0291 \\
0.0265 \\
0.0271 \\
0.0418 \\
0.0357 \\
0.0248 \\
0.0229 \\
0.0266 \\
0.0249 \\
0.0224 \\
0.0240 \\
0.0244 \\
0.0232 \\
0.0231 \\
0.0226 \\
0.0259 \\
0.0244 \\
0.0243 \\
0.0230 \\
0.0216 \\
0.0253 \\
0.0218\end{array}$ & $\begin{array}{r}9.60 \\
13.24 \\
17.83 \\
18.90 \\
30.99 \\
27.00 \\
28.08 \\
17.26 \\
19.89 \\
17.74 \\
15.53 \\
7.20 \\
6.44 \\
6.96 \\
9.27 \\
16.63 \\
13.96 \\
15.10 \\
17.96 \\
20.09 \\
19.98 \\
7.08 \\
5.70 \\
6.40 \\
7.54 \\
6.40 \\
6.57 \\
14.36 \\
14.52 \\
14.71 \\
33.37 \\
21.90 \\
12.28 \\
8.33 \\
9.03 \\
6.05 \\
8.39 \\
8.54 \\
9.13 \\
8.38 \\
9.76 \\
5.71 \\
5.42 \\
9.22 \\
11.51 \\
6.56 \\
5.63 \\
16.34 \\
7.56\end{array}$ & $\begin{array}{l}2.36 \\
1.14 \\
1.34 \\
1.59 \\
1.92 \\
2.42 \\
1.93 \\
1.55 \\
2.33 \\
1.32 \\
1.25 \\
0.99 \\
0.97 \\
0.72 \\
1.02 \\
1.22 \\
1.19 \\
1.56 \\
1.45 \\
1.55 \\
1.53 \\
0.88 \\
0.87 \\
1.05 \\
0.86 \\
0.88 \\
2.63 \\
1.23 \\
1.18 \\
1.72 \\
2.11 \\
2.70 \\
1.06 \\
0.85 \\
0.92 \\
0.89 \\
1.00 \\
0.88 \\
0.98 \\
1.22 \\
0.97 \\
1.20 \\
0.88 \\
1.36 \\
0.99 \\
0.72 \\
1.17 \\
1.35 \\
0.95\end{array}$ \\
\hline
\end{tabular}


SIIE
NUMBEY ST LAT. LONG. L TY RPL MO-DA.YA SOURCE/COND. PAFTICLE SIZE POS.
UPPER LOHER CONI Q. C. URANIUMIDNC)
X-REF POH ERR

THOR IUH INAA I

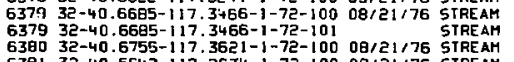

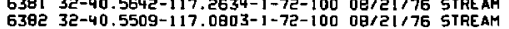
$639332-40.5816-117.0630-1-72-10008 / 22178$ STREAH $638432-40.6068-117.0461-1-70-10000 / 22 / 76$ STREAM 6385 32-40.5265-117.1322-1-72-100 09/22/76 5TAEAM 6385 32-40.5355-117.1653-1-70-100 08/22/76 5TREAM 6327 32-40.5309-117.2161-1-72-100 08/22/76 STREAH $638832-40.5041-117.1074-1-72-10000 / 22 / 77$ STREAM 6399 32-40.5185-117.0992-1-72-100 08/22/76 STREAM 32-40.5185-117.0992- $-72-101$ STREAM $639132-40.6609-117.0379-1-72-10000823176$ SIREAM $639232-40.6545-116.9196-1-72-10000 / 23 / 76$ STREAH 6426 32-40.999/-116.6196- $-72-10008 / 25 / 76$ STREAM $642732-40.9819-116.6303-1-72-19000825 / 76$ SIREAM 6428 32-40.9729-116.6244-1-72-100 08/25/76 STREAM 6429 32-40.9440-116.6175-1-72-100 08/25/76 STREAM 6430 32-40.8696-11. $7591-1-72-10000 / 26 / 07$ SIREAM 643 32-40.8606-116.7574-1-72-100 00/26/75 STREAM $643332-40.7895-115.7795-1-72-100$ 08/26,76 SIREAM $643432-407931-116.7843-1-72-10008 / 26,76$ STREAM $643532-40,0048-116,7973-1-72-100$ 08/26/76 STREAM E436 32-40.8536-116.8529-1-72-100 08/26/7E STREAM $643732-40.8581-116.0541-1-72-10008 / 26 / 76$ STREAM $643032-40.7951-115.9099-1-72-100$ 08/26/76 5TREAM $643932-40.7689-116.9135-1-72-10008 / 26 / 76$ STREAM $643932-40.7689-116.9135-1-72-101$ STREAH $644032-40.6077-116.9052-1-72-10008 / 26 / 76$ STREAM 644 ! 32-40.8302-116.9087-1-72-100 08/26/76 STREAM $644232-40.8725-116.9027-1-72-10000 / 26 / 76$ STREAH $644332-40.876 /-116.9730-1-72-10008 / 26 / 76$ STREAH $644432-40.7379-116.6968-1-72-10008 / 26 / 76$ 5TREAH 6455 32-40.7030-116.7585-1-72-100 08/26/76 STREAM $644632-40.6832-116.8095-1-72-10008 / 26 / 76$ STREAM $644832-40.9773-11 \% 3754-1-72-10008 \% 2776$ STRAH $649332-40.9790-117.4-1-72-100083276$ STREAH 5493 32-40.979-117.4-59-1-72-100 08/20/75 STREAH 6495 $32-40.961-1 . .4350-1-73-10000 / 30,76$ STREAM $669932-40-4183-117.9 \cdot 34-1-72-100$ STREAM (40.4797-112 0 185-1-72-100 09/29/76 STREAM $675932-40.4565-117.5956-1-72-10009 / 27 \%$ STREAM 6760 32-40.4834-117.6359-1-72-100 09/27/7E STRE AM

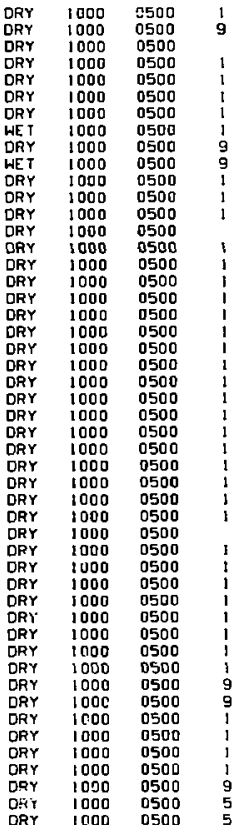

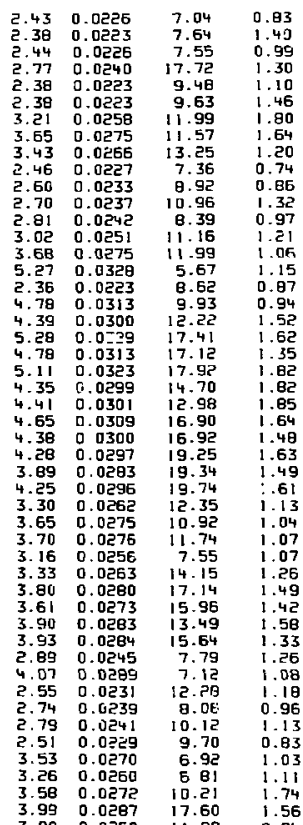

0500 
THORIUMINAAI

SITE
NUMBER ST LAT. LONG. L TY RPL MO-DA-YR SOL'RCE/COND. PARTICLE SIZE POS. Q. C. URANIUIMIONC,
$X$-REF PPM ERA PPH ERR $676232-40.4660-117.5202-1-72-10009 / 27 / 76$ STREAM $676432-40.3964-117.5786-1-72-100$ 09/27/76 STAEAM $676532-40.3756-117.5854-1-72-100$ 09/27/76 STREAM $676632-40.4458-117.5978-1-72-100$ 09/27/76 STREAM
$675732-40.3046-117.5589-1-72-10009 / 27 / 76$ STREAM $676732-40.3046-117.5589-1-72-10009 / 27 / 76$ STREAM
$676832-40.3268-117.6066-1-72-10009 / 27 / 76$ STREAH 6769 32-40.3123-1117.6249-1-72-100 09/27/76 5TREAM $680132-1 ; 1077-116.3570-1-72-100$ 09/01/76 STREAH $680232-1.0985-116.3207-1-75-100$ 0B/01176 STREAH 6003 32-40.025 $600532-40.0250-116.3391-1-752-100$ 08 $01 / 76$ STREAM $600732-40.0601)$ 680 33-40.0543-110 4830-1-72-100 0810176 STREAH $690932-40.1614-115.7229-1-72-10000 / 01 / 76$ STREAH $680932-40.1614-111.7229-1-72-101$ STREAH $691032-40.1433$. $16.6889-1-72-100 \quad 09 / 01 / 76$ STREAH $681132-40.1711-16.6348-1-72-10008 / 02 / 76$ STREAM 6812 32-40.2024-116.5805-1-72-100 STREAM 6813 32-40.2267-1:6.5581-1-72-100 08/02/76 5TAEAM $601432-40.2797-116.5212-1-72-100$ 05/04/76 STREAM $661532-40.3923-1$ $681732-40.2741-116.7307-1-72-100$ 08/04/76 STREAM $681032-40.2641-516.7154-1-72-10008 / 04 / 76$ STREAM $681932-40.2883-116.6812-1-70-100$ 08/04/76 STREAY 5819 32-40.2883-116.6812-1-70-101 20 5TREAH $682032-40.3090-116.6740-1-72-10000 / 02 / 76$ STAEAh

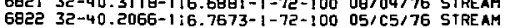
$682232-40.2066-116.7673-1-72-10005 / 65 / 76$
$682332-40.3344-116.7069-1-72-10008 / 04 / 76$
STREAM $682432-40.3690-116.3522-1-72-10008 / 03 / 76$ STREAM $682532-40.3398-116.4608-1-72-10008 / 03 / 76$ STREAM 6 626 32-40.3953-116.4179-1-72-100 08/03/76 STREAH $682732-40.4244-116.4389-1-72-100$ 19/0376 STREAM 6928 32-40.4416-116.4729-1-72-100 08/03/76 STREAM $682932-40.4776-116.4550-1-72-10008 / 03 / 76$ STREAM 6829 32-40.4776-116.4550-1-72-101 $683132-40.0400-116.8277-1-72-10008 / 05 / 76$ 5TREAH $683232-40.0598-1: 6.8511-1-72-10008 / 05 / 76$ STREAM $683332-40.0950-116.7970-1-72-100$ 08/05/76 STREAM 6834 32-40.0976-116.7924-1-72-100 08/05/76 STREAM 6935 32-40.1264-\$16.7807-1-72-100 09/05/76 5TREAH $633632-40.1129-116.7747-1-72-100$ 08/05/76 STREAM (3)-40.1471-116.7546-1-72-100 08/05/76 STREAM $684232-40.3326-116.7104-1-70-10008 / 0 ? / 76$
6 STREAM

$\begin{array}{llll}\text { ORY } & 1000 & 0500 & 9 \\ \text { DRY } & 1000 & 0500 & 5 \\ \text { DRY } & 1000 & 0500 & 9 \\ \text { DRY } & 1000 & 0500 & 5 \\ \text { DRY } & 1000 & 0500 & 5 \\ \text { DRY } & 1000 & 0500 & 5 \\ \text { DRY } & 1000 & 0500 & 5 \\ \text { DRY } & 1000 & 0500 & 1 \\ \text { ORY } & 1000 & 0500 & 1 \\ \text { DRY } & 1000 & 0500 & 1 \\ \text { DRY } & 1000 & 0500 & 1 \\ \text { DRY } & 1000 & 0500 & 1 \\ \text { DRY } & 1000 & 0500 & 1 \\ \text { nRY } & 1000 & 0500 & 1 \\ \text { DRY } & 1000 & 0500 & 1 \\ \text { DRY } & 1000 & 0500 & 1 \\ \text { DRY } & 1000 & 0500 & 1 \\ \text { DRY } & 1000 & 0500 & \\ \text { DRY } & 1000 & 0500 & 1 \\ \text { DRY } & 1000 & 0500 & 1 \\ \text { DRY } & 1000 & 0500 & 1 \\ \text { ORY } & 1000 & 0500 & 1 \\ \text { DRY } & 1000 & 0500 & 1 \\ \text { HET } & 1000 & 0500 & 1 \\ \text { DRY } & 1000 & 0500 & 1 \\ \text { DRY } & 1000 & 0500 & 1 \\ \text { DRY } & 1000 & 0500 & 1 \\ \text { HET } & 1000 & 0500 & 1 \\ \text { WET } & 1000 & 0500 & \\ \text { DRY } & 1000 & 0500 & 1 \\ \text { DRY } & 1000 & 0500 & 1 \\ \text { DRY } & 1000 & 0500 & 1 \\ \text { DRY } & 1000 & 0500 & 1 \\ \text { ORY } & 1000 & 0500 & 1 \\ \text { DRY } & 1000 & 0500 & 1 \\ \text { DRY } & 1000 & 0500 & 1 \\ \text { DRY } & 1000 & 0500 & 1 \\ \text { DRY } & 1000 & 0500 & 1 \\ \text { DRY } & 1000 & 0500 & 1 \\ \text { DRY } & 1000 & 0500 & 1 \\ \text { DRY } & 1000 & 0500 & 1 \\ \text { DRY } & 1000 & 0500 & \vdots \\ \text { ORY } & 1000 & 0500 & 1 \\ \text { ORY } & 1000 & 0500 & 1 \\ \text { ORY } & 1000 & 0500 & 1 \\ \text { DRY } & 1000 & 0500 & 1 \\ \text { ORY } & 1000 & 0500 & 1 \\ \text { DRY } & 1000 & 0500 & 1 \\ \text { WE T } & 1000 & 0500 & 1 \\ & & & \end{array}$

2. 790.0241 כ. $19 \quad 0.0215$ $\begin{array}{rl}2.73 & 0.0238 \\ 3.65 & 0.0235\end{array}$ 3.320 .0236 $\begin{array}{ll}.32 & 0.0262 \\ .28 & 0.0261\end{array}$ .80 0.0280 $\begin{array}{lll}3.78 & 0.0241\end{array}$ 3.770 .0279 3. 0.035 $\begin{array}{lll}3.33 & 0.0263\end{array}$ 3.050 .0252 8.650 .0419 $4.00 \quad 0.0287$ 3.750 .0287

4.750 .0278
4.690 .0310

$4.38 \quad 0.0300$

$6.35 \quad 0.0360$

$2.05 \quad 0.0244$

4.220 .0295 2.59 0.0232 $2.73 \quad 0.0239$ $3.92 \quad 0.0284$ $3.39 \quad 0.0265$

$\begin{array}{ll}3.63 & 0.0274 \\ 4.07 & 0.0289\end{array}$

$4.07 \quad 0.0289$ 4.150 .0292 5.930 .0348 2.80 0.0242 $\begin{array}{ll}\text { 日. } & 0.0424\end{array}$ $\begin{array}{ll}3.63 & 0.0274\end{array}$ 3.37 0.029 3.340 .0263 3.85
5.0 .0545 3.050 .0252 3.050 .025 $3.49 \quad 0.0268$ $3.10 \quad 11.0254$ 3.82 is.0281 3.490 .0269 $3.44 \quad 0.0267$ $4.78 \quad 0.0313$ $4.28 \quad 0.0296$ $3.95 \quad 0.0295$

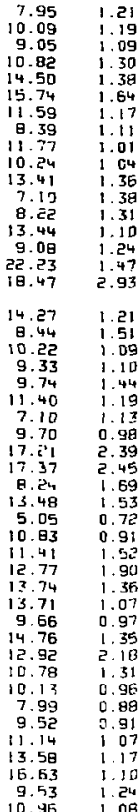




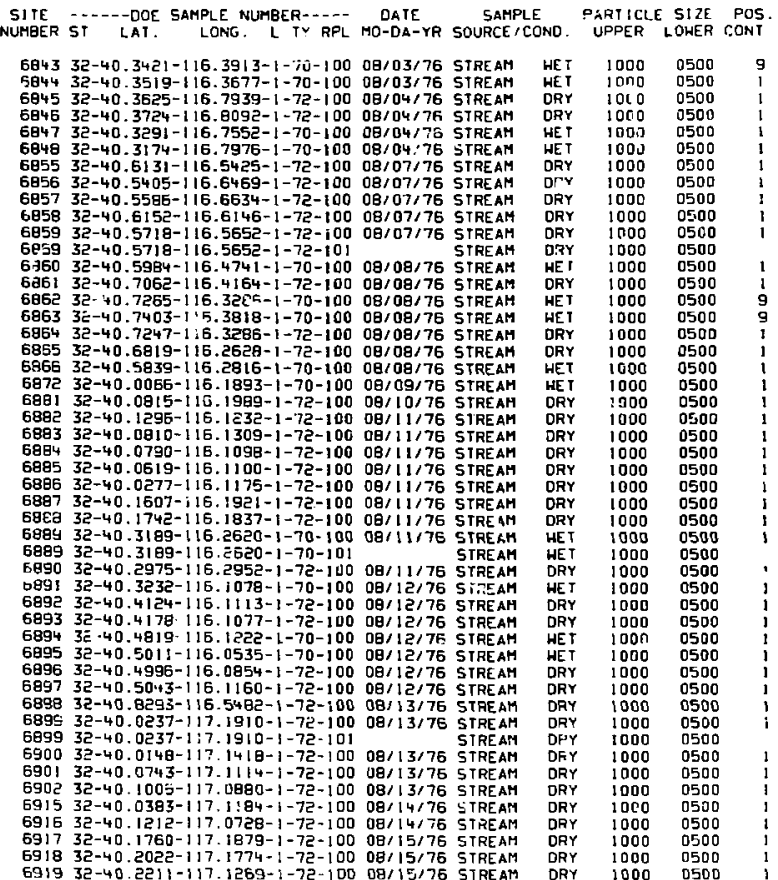

Q. C. URANIUHADNC)

THOR I UM INAA)

$.49 \quad 0.65$

5.69 0.0237

$4.43 \quad 0.0302$

$5.29 \quad 0.0329$

$\begin{array}{lll}3.11 & 0.0254\end{array}$

4.170 .029

5.05 0.0321

3.710 .027

3.990 .0286

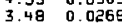

4.110 .0291

$\begin{array}{ll}2.95 & 0.0244 \\ 2.74 & 0.0239\end{array}$

$\begin{array}{ll}2.74 & 0.0239 \\ 3.37 & 0.0264\end{array}$

3.360 .026

3.840 .0281

3.550 .027

3.550 .0271

$\begin{array}{ll}3.85 & 0.0244\end{array}$

3.55 o.0271

$\begin{array}{ll}3.74 & 0.0278 \\ 3.39 & 0.0265\end{array}$

$\begin{array}{ll}3.39 & 0.0265 \\ 3.35 & 0.0264\end{array}$

3.090 .0253

$3.33 \quad 0.0263$

$3.5110 .027:$

$3.58 \quad 0.0272$

$\begin{array}{ll}3.61 & 0.0273 \\ 3.60 & 0.0273\end{array}$

3.210 .025

$\begin{array}{ll}3.58 & 0.0272 \\ 3.20 & 0.0258\end{array}$

3.590 .0272

$3.00 \quad 0.0250$

$3.5 \overline{3} 0.0270$

3.530 .025

2. 010.0242

3.060 .0252

$\begin{array}{ll}3.43 & 3.0226\end{array}$

$\begin{array}{ll}3.46 & 0.0267\end{array}$

4.510 .0307

4.590 .0307

$\begin{array}{lll}6.43 & 0.0362\end{array}$

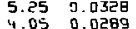

0.45

$9.70 \quad 1.35$

$5.11 \quad 0.75$

$7.52 \quad 1.84$

$\begin{array}{ll}15.64 & 2.69 \\ 12.05 & 2.61\end{array}$

$17.38 \quad 1.64$

$\begin{array}{ll}18.41 & 1.61 \\ 12.71 & 1.10\end{array}$

$7.77 \quad 1.66$

7.31
12.57

12.57 2.1

$14.41 \quad 1.29$

0.95

$12.14 \quad 2.35$

11.04

$0.20 \quad 1.04$

$\begin{array}{ll}6.26 & 2.64 \\ 11.57 & 1.29\end{array}$

$16.61 \quad 1.63$

$16.33 \quad 1.71$

9.02 0.85

$\begin{array}{rr}9.02 & 1.95 \\ 11.87 & 2.02\end{array}$

12. $24 \quad 1.14$

$7.01 \quad 0.05$

$\begin{array}{rr}9.24 & 1.03 \\ 10.25 & 1.00\end{array}$

$7.47 \quad 0.93$
11.70

$\begin{array}{ll}6.03 & 0.87\end{array}$

$15.29 \quad 2.20$

10.1日 1.70

$\begin{array}{ll}7.97 & 0.69\end{array}$

$\begin{array}{rr}11.45 & 1.57 \\ 8.36 & 1.50\end{array}$

23. $30 \quad 1.70$

$18.25 \quad 1.48$ 
SITE -.----DOE SAMPLE NUMBER--... DATE TABLE B-1. SEDIHENT ANALYSIS: DRY AND STREAT SITES
THORIUHINAA)

$23.66 \quad 2.10$ $\begin{array}{rr}1.66 \\ 9.61 & 0.97\end{array}$ $10.71 \quad 1.81$ $18.78 \quad 1.58$ $18.98 \quad 1.45$ $13.67-1.34$ $8.95 \quad 1.14$ $\begin{array}{ll}10.11 & 2.31 \\ 1.74 & 1.16\end{array}$ $7.04 \quad 1.39$ $3.18 \quad 0.0257$ $3.45 \quad 0.0267$

$4.65 \quad 0.0305$ 

MABER ST LAT. LONG. L TY DATE SAMPLE PARTICLE SIZE POS.
UPPER LOHER CONT

6965 32-4C.J065-116.7451-1-72-100 08/22/76 STREAM ORY $696632-40.6084-116.7624-1-70-10008 / 20 / 76$ STREAH $696732-40.5813-116.7613-1-70-10008 / 23 / 76$ STREAM $700532-40.9877-116.8110-1-72-10008 / 25 / 76$ STREAM $700632-40.9392-116.8693-1-70-10006 / 25 / 76$ STREAT $700032-40.962-116.03403-12-100$ 0B/E $700932-40.9409-116.7957-1-72-10000125176$ STREAH $70093240.9409-116.7957-1-72-101$ STREAM $701032-40.9372-116.7779-1-72-100$ 08/25/75 STREAM $701132-40.9426-116.7660-1-72-10008 / 25 / 75$, STREAM $701232-40.9830-116.7000-1-70-100$ 00/25, /6 STREAM $701332-40.9587-116.7113 \cdot 1-70-10008 / 23 / 76$ STREAM $701432-40.8948-116.6979-1-70-10009 / 26 / 76$ STREAM $701532-40.9245-116.7078-1-72-100$ 08/26/76 STREAM $701632-40.9398-116.7101-1-72-10009 / 26 / 76$ STREAM $701732-40.9230-116.9299-1-72-10009 / 26 / 76$ STREAM $701832-40.9365-116.9513-1-72-100$ 08/26/76 STREAM $701932-40.9708-115.9513-1-72-100$ 08/26/76 5TREAM $702032-40.9861-115.9251-1-72-100$ 80/06/76 STFEAM $702332-40.9464-116,9073-:-72-100$ 08/26/76 STREAM $702432-40.9347-116.8800-1-72-100$ 08/26/76 5TREAH $702532-40.9201-116.9086-1-72-10009 / 26 / 76$ SIREAM 7027 32-40.8025-116.5073-1-7c-100 08/56/76 STREAH 7029 32-40.7747-116.6445-1-72-100 08/20/76 517. $702932-40.7747-136.6445-1-72-101$ SIREAM $703032-40.7604-1$ i6. 6624-i-72-100 09/26/76 5TREAM $703132-40.9556-117.4147-1-72-100$ 08/27/75 SIREAM $703232-40.9890-117.3911-1-72-10009 / 26 / 76$ SIREAH $706632-40.9313-1.77,4157-1-72-10009 / 30 / 76$ SIREAM $707532-40.9788-117.4838-1-70-10008 / 30 / 76$ STREAM $707732-40.9793-1173169-1-72-10008 / 30,76$ STREAH $707832-40.9127-117.2980-1-72-10000 / 30 / 76$ STREAM 7079 32-40.9206-117.2969-1-72-100 08/30/76 STREAM $707932-40.9226-117.2969-1-72-101090$ STREAM $715032-40.072 !-117.8526-1-72-10010 / 03: 76$ STREAM $715232-40.4243-1175717-1-70-10010104776$ STREAM $715332-40.4324-117.5671-1-70-10010 / 04 / 75$ STREAH $715532-40.4444-117.5200-1-72-10010 / 04775$ STREAM 7156 32-40.4858-117.5321-1 -70-100 10/04/75 STREAH $715832-40.3215-117.5932-1-70-1$ 7159 32-40.3163-117.5500-1-70-160 10104/70 STREAH $716032-40.3154-117.5495-1-70-10010 / 04175$ STREAM ORY HET 1000 DRY 1000 DRY 1000 DRY 1000 DaY 1000

\section{Q. C. URANIUM IONC)}

$4.07 \quad 0.0289$

$\begin{array}{ll}4.07 & 0.0289 \\ 4.69 & 0.0297\end{array}$

$\begin{array}{ll}4.55 & 0.0398\end{array}$

$\begin{array}{ll}.64 & 0.0309\end{array}$

$\begin{array}{ll}53 & 0.0324\end{array}$

$5.20 \quad 0.0326$

$7.35 \quad 0.039$

5. 83 0.0345

4.490 .0260

$\begin{array}{ll}4.49 & 0.0303 \\ 4.39 & 0.0300\end{array}$

2.37 0.0223

3.270 .0326

3.08
4.0290

$\begin{array}{ll}4.59 & 0.0307 \\ 6.80 & 0.0372\end{array}$

4.380 .0300

3.000 .035

$7.42 \quad 0.0388$

$3.68 \quad 0.0276$

$4.30 \quad 0.0297$

$4.88 \quad 0.0336$

$3.05 \quad 0.0 r^{31}$

$\begin{array}{ll}3.48 & 0.0528\end{array}$

2.86
3.0 .0344

$3.26 \quad 0.0260$

$\begin{array}{ll}3.03 & 0.02131\end{array}$

. 68.0245

$\begin{array}{ll}3.19 & 0.0257\end{array}$

2. $45 \quad 0.0227$

$\begin{array}{rl}5.53 & 0.0230\end{array}$

$2.44 \quad 0.0226$

$\begin{array}{ll}3.10 & 0.0210 \\ 3 & 3.510\end{array}$

$\begin{array}{ll}3.64 & 0.0274 \\ 3.21 & 0.0258\end{array}$

2.80 0.0242

$\begin{array}{rl}2.80 & 0.0242 \\ 4.97 & 0.0319\end{array}$

2. $96 \quad 0.0248$

$\begin{array}{ll}2.70 & 0.0237\end{array}$
IHOR I UMA (NAA)

$4.57 \quad 0.75$

$7.32 \quad 0.79$

31. $03 \quad 0.95$

$\begin{array}{ll}8.11 & 2.29\end{array}$

$18.77 \quad 3.29$

$0.94 \quad 1.45$

1. 15

$\begin{array}{ll}7.35 & 3.14\end{array}$

$14.62 \quad 1.12$

$\begin{array}{ll}14.72 & 1.34 \\ 18.56 & 1.82\end{array}$

$\begin{array}{ll}18.40 & 1.45\end{array}$

$\begin{array}{ll}18.64 & 1.55 \\ 16.64 & 1.35\end{array}$

$17.82 \quad 1.35$

$18.39 \quad 1.42$

1.81
16.54

$\begin{array}{ll}22.47 & 1.67\end{array}$

$14.95 \quad 1.55$

$\begin{array}{ll}18.45 & 1.64 \\ 19.43 & 1.74\end{array}$

$18.65 \quad 2.99$

11.442 .00

$12.69 \quad 1.12$

6.

B. $33 \quad 0.96$

7.ce 1.00
0.98

$\begin{array}{ll}9.78 & 1.03 \\ 6.92 & 1.32\end{array}$

8.77 $\quad 1.62$

\begin{tabular}{l|l}
8.81 & 1.16
\end{tabular}

$13.78 \quad 1.16$

13.09

\begin{tabular}{r|r}
9.83 \\
16.70
\end{tabular} 
$716132-40.5878-117.1560-1-70-10010 / 04 / 76$ SIREAM 7I6e 32-40.5807-117.1572-1-70-100 10/05/76 STREAM $716332-40.5175-117.1700-1-72-10010 \% 05 / 76$ STREAM $716432-40.5276-117.4380-1-70-10010 / 05 / 76$ STREAH: $716532-40.4888-117.4543-1-70-10010705 / 76$ STREAM

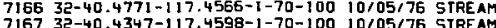
$716732-40.4347-117.4598-1-70-10010 / 05 / 76$ STREAM 7169 32-40.3806-117.4795-1-70-100 10/35/76 STREAM 7170 32-40.3725-117.4065-1-70-100 10/05/76 STREAM DO $717332-40.2505-117.3493-1-72-100$ 10 7174 32-40.2378-117.3633-1-72-100 $10 / 05 / 76$ SIREAM 7201 32-40.4402-117.6320-1-72-100 09,27, STREAM $720232-40.4420-117.6379-1-72-100$ 09/27/75 5TREAH 7203 32-40.4518-117.6533-1-72-100 09/27/76 5TREAH 7204 32-40.4463-117.6733-1-72-100 09/27/76 5TREAM $720532-40.4111-117,6859-1-72-10009 / 27 / 76$ 5TREAM $720632-40.4011-117.6988-1-72-10009 / 27 / 76$ - TREAN $720732-40,3948-117.6964-1-72-10009 / 27 / 76$ STREAM 7208 32-40.3633-117.6972-1-72-100 09/27/76 STREAM 7209 32-40.3416-117.7041-1-72-100 09927/76 STREAM 7211 32-40.3103-117.6731-1-72-100 09/27/76 STHEAM $721232-40.2911-117.7118-1-72-100$ 09/27/76 STREAM $721332-40.2685-117,7221-1-72-10009 / 27 / 75$ STREAM 7214 32-40.2531-117.7337-1-72-100 09/27/76 STREAM $721532-40.2369-117.7347-1-72-10009 / 27 / 76$ STREAM 72 : 32-40.2206-117.7404-1-72-100 09/27/73 STREAM 7210 7219 32.40.1331-117.7760-1-7e-100 09/28,76 STREAM $723032-40,1891-117.7424-1-72-10$ 7221 32-40.2008-117.7402-1-72-100 09/20/76 STRCAM $723232-40.4002-117.4621-1-72-100$ 09/29 $723332-40.4302-117.4521-1-72-10009 / 20 / 75$ 5TRTAM 7224 32-40.4437-117.4510-1-72-100 09220176 5TRCAM $722532-40.4591-117.45 / 6-1-72-100$ 09/28/75 5TREAM $722632-40.4628-117,4246-1-72-10009 / 28 / 7 E$. STREAM $722732-40.4655-117,4211-1-72-10009 ; 29 / 76$ P. IREAM $722832-40.4863-117.4106-1-72-10009 / 28 / 76$ STRE AM $722932-40.529 \mid-117.5112-1-72-10009 / 28 / 7$. STREAH $723032-40.5511-117.4181-1-72-100$ 09/28/76 SIREAM $723132-40.5756-1: 7.3816-1-72-100$ 09/28/76 STREAM $723232-40.5801 \cdot 117,3533-1+72-100 \quad 09 / 28 / 76$ STREAM $723332-40.5171-117.3352-1-72-100$ 09/29/75 5TRE.AM

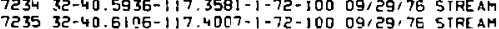

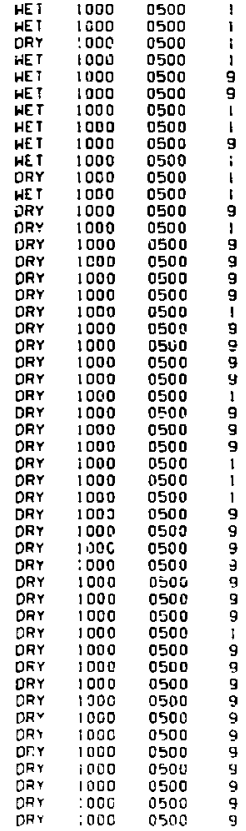

\begin{tabular}{|c|c|c|c|}
\hline 2.66 & 0.0236 & 5.54 & 0.96 \\
\hline & 0.0259 & 11.16 & 1.30 \\
\hline 70 & 0.0237 & 8.94 & $i .03$ \\
\hline 3.03 & D. 0251 & 10.30 & \\
\hline 2.63 & 0.0234 & 10.89 & 1.01 \\
\hline 2.54 & 0.0231 & 8. 10 & 1.06 \\
\hline 1.68 & 0.0200 & 5.80 & 0.80 \\
\hline & 0.0239 & 7.67 & 1.15 \\
\hline 05 & 0.0244 & 8.70 & 1.21 \\
\hline .20 & 0.0326 & 10.26 & 1.50 \\
\hline 5. 00 & 0. 0250 & 9.05 & \\
\hline .03 & 0.0351 & 22.71 & 1.89 \\
\hline .52 & 0.0336 & 14.93 & 1.42 \\
\hline & D. 0314 & 23.32 & 1.83 \\
\hline 98 & 0.0319 & 17.15 & 151 \\
\hline 3.00 & 0.0250 & 13.04 & 1.28 \\
\hline & $0.018 ?$ & & \\
\hline 3.20 & 0.0258 & 6. 56 & 1.48 \\
\hline $\mid \begin{array}{l}.56 \\
1.6\end{array}$ & 0.0183 & 5. 34 & 162 \\
\hline 1.65 & 0.0178 & 4.97 & 0.98 \\
\hline $\begin{array}{l}3.23 \\
1.98\end{array}$ & 0.0261 & $\begin{array}{r}11,47 \\
4.60\end{array}$ & $\begin{array}{ll}1 & 18 \\
1 & 02\end{array}$ \\
\hline $\begin{array}{l}1.98 \\
2.43\end{array}$ & 0.0226 & 7.24 & $\begin{array}{ll}1 & 0 c \\
1 & 03\end{array}$ \\
\hline 1.87 & 0.0199 & 6.38 & \\
\hline 2.01 & 0.0206 & 7.30 & \\
\hline 06 & 0.0322 & 18.45 & 158 \\
\hline 2.76 & 0.0240 & 949 & 15 \\
\hline 5.77 & 0.0343 & & \\
\hline 6.81 & 0.0372 & 7308 & \\
\hline 5 & 0.0271 & 1596 & 139 \\
\hline 2.65 & 0.0235 & 104 & $1: 8$ \\
\hline 2.05 & 0.0244 & 11.05 & : \\
\hline 2.71 & 0.0238 & 8.25 & $i$ \\
\hline & 0.0196 & 564 & $\therefore$ \\
\hline 6 & $0 \quad 0235$ & 0.95 & 0 is. \\
\hline .95 & ก 0204 & 795 & $i$ \\
\hline & $0.0 ? 3 \mathrm{c}^{3}$ & 8 & i \\
\hline 00 & 0.0250 & D. 86 & 10 \\
\hline & 0033 & b. & 103 \\
\hline$\vec{z}$ & $0 \quad 0261$ & A $\cdots$ & 1 \\
\hline o & 0.0241 & 189 & $1 \therefore$ \\
\hline 5 & $0\left[1 P B_{C}\right]$ & Wh & : \\
\hline 4 & 00 & $4+6$ & \\
\hline 7 & $\begin{array}{lll}0 & 0 & \\
3 & 3 \mathrm{~A}\end{array}$ & $\because \because \therefore$ & $\vdots$ \\
\hline & J $113+c$ & a $3 c^{\prime}$ & $i$ \\
\hline & לידים ט ט & $\Leftrightarrow 8$ & \\
\hline & T. 01049 & $1: \therefore 4$ & \\
\hline 4 & (1. 0, Obt) & 1.4 & $\therefore$ \\
\hline & ןלבכ & +13 & ו' \\
\hline
\end{tabular}


$605 \quad 0 \quad 0235$

3 14 00255

$\begin{array}{lll}5 & 0.0256\end{array}$

I. 960.0204

$348 \quad 0.0269$

39
30.0354

$\begin{array}{llll}55 & 0 & 0162 \\ 1.32 & 0 & 0164\end{array}$

2. 750.0240

$556 \quad 0.0 r^{3} 31$

$\therefore 790.03^{4}$

$\begin{array}{ll}2.02 & 0.020^{-} \\ 2.31 & 0.0250\end{array}$

$\begin{array}{ll}3.11 & 0.0254 \\ 3.52 & 0.0270\end{array}$

$\begin{array}{ll}3.52 & 0.0270 \\ \text { 2. } 64 & 0.0235\end{array}$

c.s 0.0215

$400 \quad 0 \quad 0287$

4 if 0.0354

3.200 .0258

3.180 .0257

5.6800340

6. 0 2 0.0350

16.490 .0576

3.9000284

5.740 .0342

3. 5200270

$\begin{array}{ll}2.51 & 0.0229 \\ 5.39 & 0.0332\end{array}$

$\begin{array}{ll}5.39 & 0.0332 \\ 3.08 & 0.0253\end{array}$

3 25 0 U259

3 91 0.0246

970.0249

3 his 0.0273

द. 35 व $024 \mathrm{~B}$

205 (1. 0240

द. 53 a 0231

?) $7 \mathrm{~B}$ त 024 :

as : :

$958 \quad 1 \quad 80$

6) 0 1 $10 \mathrm{c}^{2}$

16 17 1

$104 \quad 1$ 14

6) 100

$\begin{array}{llll}1: 64 & 64 \\ 10 & 95 & 94\end{array}$

in का

I.2 85 I

$\begin{array}{llll}11 & 91 \\ 11 & 1 & 1 & 14 \\ 11 & 11\end{array}$

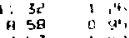

lis 60 , 46

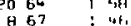

苗昰

13.96

14. 195

$1950 \quad 169$
4400

115

25. 00 '

21 $49 \quad 334$

1901 सh

$\begin{array}{lll}1 & 55 & 11 \\ 1< & 1 & 11\end{array}$

$1: 58 \quad: \quad 5$

1393

a la $1 \mathrm{bs}$

4 is 1 ? 


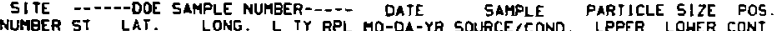

$733532-40.6192-117.2305-1-72-100$ 09/29/76 STREAH $733632-40.6309-117.2223-1-72-10009 / 29 / 76$ STREAM $733732-40.6200-117.2542-1-72-10009 / 29 / 76$ SIREAH $744132-40.9982-117.7241-1-70-10008 / 25 / 76$ STREAH $744232-40.7050-116.5301-1-70-10009 / 25 / 76$ STREAK $744332-40.5793-116.2651-1-70-10008 / 25 / 76$ STREAM 7452 32-40.0427-117. $1993-1-70-100$ 09/14/76 STREAH 7460 32-40.9607-117.4931-1-70-100 09/20/76 STREAM $746932-40.6848-116.1527-1-70-100$ 00/31/76 STREAM 7470 32-10.6848-116.1527-1-70-101 360 STREAH $747132-40.7656-116.2382-1-70-100$ 09/31/76 STREAH $747232-40.9670-116.1919-1-70-10008 / 31 / 76$ STREAM 7473 32-40.8997-116.1060-1-70-100 09/01/76 STREAM $748232-40.0065-116.1635-1-70-100$ 09/08/76 STREAM 7483 32-40.2103-116.0717-1-70-100 09/08/76 STREAM $748432-40.2274-116.0703-1-70-100$ 09/08/76 51REAM $748532-40.3255-116.0583-1-70-100$ 09/09/75 5T REAM $748632-40.2484-116.3780-1-70-100 \mathrm{Cg} / 99 / 76$ 5T 'EAM 7487 32-40.1250-116.4765-1-70-100 09/09/76 5T!.EAM $749232-40.4184-116.5061-1-70-10009 / 11 / 76$ STREAH $749332-40.2068-116.5394-1+70-10012 / 12 / 76$ STREAM $749432-40.1521-116.6208-1-70-100$ 09/12/76 STREAP $749532-40.3920-116.6899-1-70-10009 / 12 / 76$ STREAM $749632-40.3904-116.8139-1-70-10009 / 12 / 76$ STREAM $749732-40.6171-116.4337-1-70-10009 / 13 / 76$ STREAM $749932-40.6536-117.0875-1-70-100$ 09/13/76 STREAM $750032-40.6536-117.0875-1-70-10009 / 14 / 76$ STREAM $750132-40.7859-116.8044=1-70-10009 / 2376$ STREAH $751532-40.1266-116.9131-1-70-10010 / 02 / 76$ 5TREAM $751632-40$. $3077-116.7933-1-70-100$ 10,C2/76 5TREAH

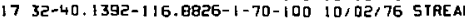
$751832-40.1914-117.1057-1-70-10010 / 03 / 76$ STREAM $751932-40.0953-1173918-1-70-10010 / 03 / 76$ STREAH $751932-40.0553-117.3919-1-70-101$ STREAM $752032-40.2086-117.0200-1-70-100: 0,03 / 76$ 5IREAM 752 ! 32-40.8298-117.3048-1-70-100 i 0/04,76 5TREAM $752232-40.7616-117.4893-1-70-10010 / 04 / 76$ STREAM 7523 32-40.8639-117.3489-1-70-100 10/04/76 5TREAM $752432-40.6046-117.5477-1-70-10010 / 04 / 75$ STREAM $752532-40.6964-1[7.5651-1-70-10010 / 04 / 76$ 5IREAM S2-40.938:-117.6763-1-70-100 10,05/76 STREAH $752732-40.9410-117.6474-1-70-100 \quad 10 / 05 / 76$ STREAM 7529 32-40.5032-117.6499-1-70-100 10,09,76 STREAM $752932-40.5032-117.6489-1-70-101$ $753032-40.5776-1: 7.7148-1-70-100 \quad 10,09 / 7 C$ STREAM a.

URANIUH IONE I
PPM ERR

HOR I UM (NAA)

$3.05 \quad 0.0252$

3.410 .0266

$3.53 \quad 0.0270$

3. $22 \quad 0.0258$

$3.72 \quad 0.0277$

2.58 0.023

6.210 .0356

6.470 .0363

1.71
3.0 .0191

15.330 .0556

B. 190.0400

2.99 0.0249

4.100 .0290

5. 170.0325

$3.44 \quad 0.0267$

2.90 0.0246

0.390 .0101

$24.64 \quad 0.0704$

$4.66 \quad 0.0309$

4.770 .031

4.310 .029

$\begin{array}{ll}3.75 & 0.0278\end{array}$

6.700 .036

2. 170.0214

$3.56 \quad 0.0271$

2.52 0.0230

4.440 .030

0.190 .007

$9.11 \quad 0.0429$

1.36 0.04?

$.50 \quad 0.0329$
0.52

0.520 .0122

1.650 .0180

$2.47 \quad 0.0228$

7.550 .0392

$3.66 \quad 0.0275$

$4.07 \quad 0.0289$

$0.57 \quad 0.0126$

$0.70 \quad 0.0128$

$\begin{array}{ll}2.42 & 0.0225 \\ 3.01 & 0.0250\end{array}$

12.15

1. 35

1. 34

$\begin{array}{ll}9.63 & 0.94\end{array}$

$9.72 \quad 1.36$
1154

$11.54 \quad 1.18$

$16.93 \quad 2.79$

$0.65 \quad 1.21$

$\begin{array}{ll}9.68 & 1.08 \\ 8.34 & 1.23\end{array}$

$11.50 \quad 1.26$

$\begin{array}{rr}1.03 & 1.16 \\ 6.69 & 1.27 \\ 9.32 & 1.57\end{array}$

$11.59 \quad 2.05$

$\begin{array}{ll}7.83 & 1.44\end{array}$

$7.05 \quad 1.33$
$4.90 \quad 0.07$

$8.86 \quad 0.87$

$13.52 \quad 1.88$

$\begin{array}{ll}15.39 & 1.52 \\ 15.47 & 1.41\end{array}$

$7.80 \quad 1.19$

$16.01 \quad 1.65$

$\begin{array}{ll}9.91 & 0.89\end{array}$

$8.65 \quad 1.75$

$19.87 \quad 1.52$

$16.74 \quad 1.53$

0.89

$5.42 \quad 1.26$

8. 020.96

1.44

$\begin{array}{ll}1.63 & 1.69 \\ 8.89 & 1.06\end{array}$

$1.94 \quad 1.11$

$5.05 \quad 1.49$

$\begin{array}{rr}11.91 & 1.48 \\ 7.49 & 0.90\end{array}$ 
SITE -...-DOE SAMPLE NUMAER--.- DATE SAMPLE PARTICLE SIZE POS.

Q. C. URANIUMIDNC)

THORILIMINAA

$7548 \quad 32-40.4196-117.4149-1-70-100 \quad 10 / 28 / 76$ STREAM

$\begin{array}{llll}\text { HET } & 1000 & 0500 & 1 \\ \text { HET } & 1000 & 0500 & 1 \\ \text { HET } & 1000 & 0500 & 1 \\ \text { HET } & 1000 & 0500 & 1 \\ \text { HET } & 1000 & 0500 & 1 \\ \text { HET } & 1000 & 0500 & 1 \\ \text { HET } & 1000 & 0500 & 1 \\ \text { HET } & 1000 & 0500 & 1 \\ \text { OFY } & 1000 & 0500 & 1 \\ \text { HET } & 1000 & 0500 & 1 \\ \text { HET } & 1000 & 0500 & 1 \\ \text { HET } & 1000 & 0500 & 1 \\ \text { HET } & 1000 & 0500 & \\ \text { HET } & 1000 & 0500 & 1 \\ \text { HET } & 1000 & 0500 & 1 \\ \text { HET } & 1000 & 0500 & 1 \\ \text { HET } & 1000 & 0500 & 1 \\ \text { HET } & 1000 & 0500 & 1 \\ \text { HET } & 1000 & 0500 & 1 \\ \text { HET } & 1000 & 0500 & 1 \\ \text { HET } & 1000 & 0500 & 1 \\ \text { HET } & 1000 & 0500 & 1 \\ \text { WET } & 1000 & 0500 & 1 \\ \text { HET } & 1000 & 0500 & 1 \\ \text { HET } & 1000 & 0500 & 1 \\ \text { WET } & 1000 & 0500 & 1 \\ \text { HET } & 1000 & 0500 & 1 \\ \text { HET } & 1000 & 0500 & 1 \\ \text { HET } & 1000 & 0500 & 1 \\ \text { WET } & 1000 & 0500 & 1 \\ \text { HET } & 1000 & 0500 & 1 \\ \text { HET } & 1000 & 0500 & 1 \\ \text { HET } & 1000 & 0500 & 1 \\ \text { HET } & 1000 & 0500 & 1 \\ \text { HET } & 1000 & 0500 & 1 \\ \text { HET } & 1000 & 0500 & 1 \\ \text { HET } & 1000 & 0500 & 1 \\ \text { HET } & 1000 & 0500 & 1 \\ \text { DAY } & 1000 & 0500 & 1 \\ \text { ORY } & 1000 & 0500 & 1 \\ \text { DRY } & 1000 & 0500 & 1 \\ \text { HET } & 1000 & 0500 & 9 \\ \text { ORY } & 1000 & 0500 & 1 \\ \text { DRY } & 1000 & 0500 & 1 \\ \text { DRY } & 1000 & 0500 & 1 \\ \text { ORY } & 1000 & 0500 & 1 \\ \text { DFY } & 1000 & 0500 & 1 \\ \text { ORY } & 1000 & 0500 & 1 \\ \text { DRY } & 1000 & 0500 & 1 \\ & & & \end{array}$

$5.67 \quad 0.0340$

$7.86 \quad 1.12$

755 32-40.2513-117.3492-1-70-100 10/20/77 SIREAH

$755232-40.494-117.6251-1-70-100$ i0 29176 SIREAH

$755532-40.0563-117.9215-1-70-10010 / 30 / 75$ STAEAH

$7556 \quad 32-40.1775-117.8515-1-70-10010 / 30 / 76$ SIREAH 7560 32-40.4070-117.8827-1-70-100 10/31/76 STREAH 7616 3e-40.6972-116.1312-1-72-100 08/31/76 STREAH $761732-40.5293-116.2113-1-70-10008 / 31 / 76$ SIREAH 7610 32-40.5494-116.0127-1-70-100 08/31/76 STREAH $761932-40.3268-116.2361-1-70-100$

$761932-40.3268-116.2361-1-70-101$ 762 32-40.3621-116.2651-1-70-100 09/10/76 SIREAH $762432-40.3761-116.3427-1-74-10009 / 12 / 36$ SIREAM $762632-40.5203-116.3425-1-70-10009 / 12776$ SIREAM $762732-40.4300-116.7666-1-70-100$ 09/13/76 SIREAH . $762932-40.3311-116.9353-1-70-100$ 09 13/76 STREAM 7630 32-40.3150-117-0635-1-70-100 09/13176 STREA 7631 32-40 $2086-117-2371-1-70-10009 / 13 / 75$ STREAM 7644 32-40 $9230-117-1093-1-70-10009 / 24 / 76$ STREAM 作 1995-117.1010-1-70-100 10/03/76 SIREAH $765732-40.6731-117.5395-1-70-10010 / 04 / 76$ SIREAH $765832-40.5605-117.5126-1-70-100$ 10/04/75 SIREAH 7653 32-40.55e7-117.4819-3-70-100 $10104 / 75$ SIREA $765032-40.5527-117.4819-1-70-101$ 10104/ $766032-40.7131-117.4617-1-70-10010 / 04 / 76$ STREAH 7662 32-40.7656-117.8545-1-70-100 10/C9/76 STREAH $766332-40.5683-117-7620-1-70-10010 / 10 / 76$ STREAH $766432-40.5647-117.8824-1-70-10010 / 10 / 75$ STREAM $766532-40.5647-117.6824-1-70-100$ 10 10\% 7666 32-40.7320-117.9142-1-70-100 10111/76 5TREAM 32-40. $7342-117.9363-1-70-10010111 / 76$ SIREAM 7701 32-40.8391-117.2052-1-72-100 09/14/75 5TAEAM $770232-40.8372-117.2147-1-72-10009 / 14 / 76$ STREAI $770332-40.8192-117.2348-1-72-10009 / 14 / 76$ 5TREAH $770432-40.8886-117.1852-1-70-10009 / 14 / 76$ STREAM $770532-40.9634-117.1628-1-72-10009 / 14 / 76$ STREAH $770632-40.9743-117.1426-1-72-10009 / 14 / 76$ SIREAH $770732-40.9861-117.0559-1-72-100$ 09/14/76 STREAH $770832-40.9140-117.0772-1-72-10009 / 14 / 76$ STREAH $770932-40.9113-117.0427-1-72-1010914176$ STREAH

3.790 .0280

$4.02 \quad 0.0288$

$\begin{array}{ll}6.06 & 0.0351 \\ 3.19 & 0.0257\end{array}$

4.75 0.0312

ट. $28 \quad 0.0219$

1.87
0.0139

$\begin{array}{ll}1.55 & 0.0231 \\ 5.75 & 0.0371\end{array}$

$\begin{array}{ll}2.52 & 0.0230\end{array}$

2.95 0.0247

$\begin{array}{ll}2.42 & 0.0225\end{array}$

ट. 270.0219

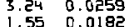

ट.16 0.0214

3.280 .0260

2. 090.0210

$\begin{array}{ll}3.17 & 0.0256 \\ 2.70 & 0.0237\end{array}$

3.030 .0251

$16.98 \quad 1.56$

3.79
11.13

$6.80 \quad 1.60$

$8.02 \quad 0.9$

$\begin{array}{ll}9.07 & 9.52 \\ 0.90 & 1.53\end{array}$

12.36

\begin{tabular}{l|l}
10.56 \\
12.24
\end{tabular}

$6.09 \quad 1.16$

$\begin{array}{ll}10.79 & 1.42 \\ 11.17 & 1.49\end{array}$

7. 76

1.34

$4.97 \quad 1.78$

$\begin{array}{rl}15.06 & 1.22 \\ 4.83 & 0.73\end{array}$

$\begin{array}{ll}9.45 & 1.59 \\ 2.00 & 0.66\end{array}$

$15.48 \quad 1.39$

$\begin{array}{ll}13 . \overline{1} & 1.68 \\ 15.04 & 1.60\end{array}$

$\begin{array}{ll}7.04 & 1.60 \\ 7.38 & 1.08\end{array}$

$12.20 \quad 4.14$

$4.83 \quad 0.64$

$12.46 \quad 2.29$

$\begin{array}{ll}10.03 & 1.13 \\ 8.95 & 1.28\end{array}$

$10.14 \quad 1.13$

$0.19 \quad 1.66$

$7.48 \quad 0.93$

$5.28 \quad 0.69$

$\begin{array}{rr}5.24 & 0.78 \\ 1.54 & 1.20\end{array}$

$7.13 \quad 1.19$

$\begin{array}{ll}7.49 & 1.09\end{array}$

$\begin{array}{rr}0.16 & 0.74 \\ 10.33 & 1.76\end{array}$ 
$51 \mathrm{TE}$ -DOE SAMPLE NUMBEP---- DATE

SAMPLE PARTICLE S:ZE DOS.

O. C. URANIUH ENC:

THOAIUMIVARI $771232-40.8437-117.0830-1-72-100$ 09/14/76 STREAH $771332-40.6643-117.1721-1-72-10009 / 14175$ STREAM $771432-40.7346-117.6407-1-70-100$ 09/15/7E STREAM $771532-40.7607-1: 7.6624-1-72-100$ 09/15/75 STREAH $771632-40.7592-117.9004-1-70-10009 / 14 / 76$ STREAM $771732-40.6932-117.6711-1-72-10009 / 14 / 76$ STREAM $771 B$ 32-40.691E-117.6344-1-70-100 09/14i76 STREAH $771932-40.6654-117.6235-1-72-10009 / 14 / 76$ STREAM $771932-40.6664-117.6235-1-72-101$ STREAH 7720 32-40.6167-:117.6443-i-72-100 09/14:76 STREAT 7) $32-40.5674-117.6025-1-72-10009 / 1476$ 5TREAM $772232-40.531 \mathrm{E}-117.68 \mathrm{1}:-1-72-100$ 09/14/76 5TREAM $772332-40.5129-117.6917-1-72-10009 / 12 / 76$ STREAM 7724 32-40.5407-117.7050-1-72-100 03/14/76 STREAM $772532-40.5551-117.7146-1-72-100$ G9'14/76 STREAM 7727 32-40.5577-117.5622-1-72-100 99,1476 STREAH $772832-40.5109-117.5441-1-70-100$ 09: : 46 STREAM $772932-40.5273-117.5159-1-72-100$ 09. 175 STREAH STREAH $773032-40.5247-117.4994-:-7 j-i 50=5 / 14,76$ STREAH 73: 32-40-5307-117 5620-1-72-100 09,:4 T5 STREAM 7732 32-40.65i2-i17.6000-1-72-i00 09,:7/76 5TREAM 7733 32-40.6307-1:7.5591-1-72-800 99:-76 STREAM $773632-40.6210-117-5: 79-1-72-152001: 76$ STREAM $773532-40.5743-117.4855-1-70-10009 \% 7$ E STEAM $.73632-40.6696-117.53: 2-1-72-100$ 99/17/7E STREAM $773732-40.6939-117.5373-i-70-100$ 09.17-76 5TRE.AM $73632-40.7336-1: 7.5163-1-73-130$ 59:17:76 STREA.

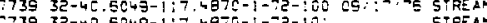
作 作

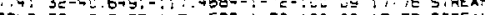

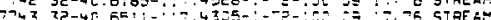

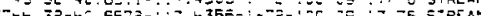
-45 $35-4$.6E7C-:

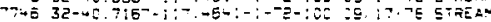

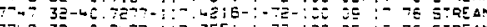

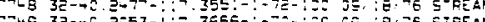
T-

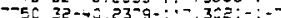

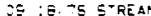

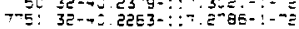

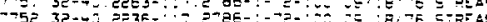

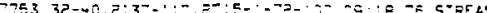
754 72-6.

WET $\quad 1000$

DRY 1050

Wet

AET

DRY IOOE

DFY

DRY 1000

DRY

DR?

DrY

DRT

DRY

OAY

HET
DRY

DA

DET
DRY

DRY

DF'

DRT

WET

DRT

DRY

WET
DRY

DRY

Dar

par

zoy

$\cos (0)$

लE:

$25:$

Do?

Da:

SE:

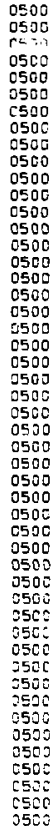

0500
0500
15010
0500
0500
0500
0500
0500
0500
0500
0500
0500
0500
0500
0500
0500
0500
0500
0500
0500
0500
0500
0500
0500
0500
0500
0500
0500
0500
0500
0500
0500
0500
0500
0500
5500
2500
5500
0500
5500
5500
5500
5500
0500
0500
0500
6500
0500
5500

$10.11 \quad 1.14$

$2.75 \quad 3.0240$

$\begin{array}{rrrr}2.75 & 0.0240 & 10.11 & 1.14 \\ 3.06 & 0.0252 & 7.35 & 1.43 \\ 2.19 & 0.0215 & 7.59 & 0.69 \\ 3.23 & 0.0259 & 15.25 & 1.42\end{array}$

14.66
14.19

$\begin{array}{llll}3.25 & 0.0260 & 14.19 & 1.19 \\ 3.61 & 0.0233 & 14.98 & 131\end{array}$

3. $03 \quad 0.0251$

$\begin{array}{rrrr}1.60 & 0.0186 & 7.90 & \vdots .12 \\ 2.66 & 0.0236 & 11.66 & .52\end{array}$

$24.19 \quad 1.6$

$3.26 \quad 0.0260 \quad 11.72 \quad: .34$

3. $550.0255 \quad 12.56 \quad 3.60$

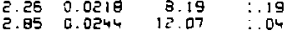

$\begin{array}{llll}2.85 & 0.0244 & 12.07 & : .04 \\ 2.94 & 0.0247 & 30.22 & \vdots .89\end{array}$

$\begin{array}{llll}3.77 & 0.0279 & 13.14 & 1.72 \\ 4.46 & 0.0303 & 15.99 & 2.02\end{array}$

4.570 .0306

4.570 .0306

3.740 .0370 2i.j5 1.39

$\begin{array}{llll}3.74 & 0.0278 & 14.57 & 1.35 \\ 2.84 & 0.0243 & 13.98 & 1.23 \\ 2.12 & 0.0212 & 0.17 & 6.96\end{array}$

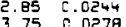

$3.44 \quad 0.0267$

$\begin{array}{llll}1.44 & 0.0159 & 5.16 & 1.26\end{array}$

$\begin{array}{llll}4.37 & 0.0300 & 15.85 & 1.63\end{array}$

$\begin{array}{llll}2.51 & 0.0229 & 5.22 & 3.90 \\ 2.35 & 0.0252 & 6.02 & 1.20\end{array}$

2. $370.0223 \quad 7.69 \quad 2.83$

$\begin{array}{llll}2.20 & 0.0215 & 8.26 & 3.73 \\ 2.65 & 0.057 & 9.59 & 5.95\end{array}$

$\begin{array}{llll}2 . i t & 0.0213 & 5.92 & 1.5 \\ 26 & 0.0209 & -.76 & \text { BE }\end{array}$

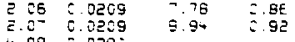

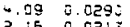

5.59 o. 0335

$4.65 \div 63.09$

6.12 0.0353

उe $=\frac{2}{2}$

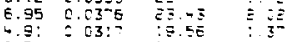

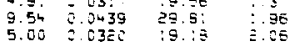

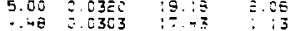




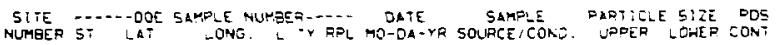

$775632-40.067 \div-117.2979-1-72-10009117175$ STREAM

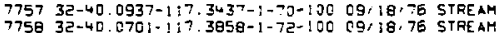
$775832-40.0701-117.3658-1-72-10009 \% 38,76$
$775932-40.6711-117.3694-1-72-100$ STREAH $775932-40.07 ! 1-117.3694-1-72-101$ OO SIREAM $776032-40.0627-117+315-1-72-10009,10 / 76$ STREAH $776132-0.0517-1 ; 7.4903-1-72-10009110: 76$ 5TREAM $779432-40.7355-117.1717-1-72-100$ 09/21/7E SIFEAM 7795 32-40.7229-117,1492-1-72-100 09,21/76 STREAM $779632-40.684 i-117.1953-1-72-10009 / 2\}$ 1/75 STREAM 779 3 $3-40.7291-i 11.2345-1-72-100$ 09/2) 170 STREAH $79832-40.7264-117.2143-1-72-10009 / 21$ $779932-40.6959-117.1911-1-72-10109 / 21 / 78$ $780032-40.0131=117.4577-1-72-100$ 09/22:76 STREAM 780: $32-40.8252-117.4471-i-72-: 00$ 09/22/78 STREAM $780232-40.8186-1: 7.4399-1-72-10009 / 22 / 76$ STREAM $780432-0.0322-117.4104-1-72-10009 / 22 / 76$ STREAM 7005 32-40.8139-1i 7.j T2 7907 32-40.7589-:17.1924-1-72-100 09ie2/76 STREAM 7810 T2-40.769-117.2442 $1-72-100$ STAEAM 7811 32-40.7503-117. $781233-40.79020-117-2739-1-72-100$ 09/23/7E STREAH $78: 3$ 32-40.8137-117.2081-1-72-100 09/23/7E SYREAH 7814 32-40.7946-117.3532-1-72-100 09/23/76 SIRFAM 7815 32-40.7656-117.3957-1-72-100 09/23/76 STREAM $781632-40.7607-117.4928-1-72-10009 / 23 / 76$ STREAM 7899 3e-40.0962-117.9983-1-72-100 09/29/76 STREAM $789032-40.0723-117.9487-1-70-10009 / 29 / 76$ SIREAM 789 32-40.9795-117.3499-1-72-100 09/29/76 STREAM 795 32-40 $572-117.9 ! 45-1-70-100$ 09/29/76 STREAH

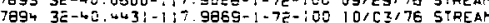

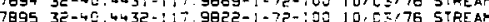
$789632-40.3095-1177955-1-70-100$ 0. 3 \% 76 5TREAM 72-40.1157-17.9180-1-72-100 :0163776 5TREAH 0. 1099 32-0 0955-117.6546-:-72-100:0103\%75 5TRERM

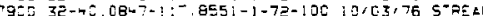

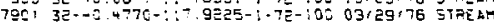
7962 32-40.47-9-1: 9663-1-72-100 09,E9/75 STREAM

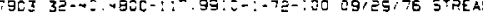
-904 3E-- - -8SC-!:" 99E?-:-72-:00 09,29:75 STPEAM

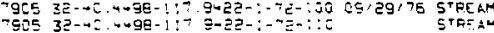

$\underset{x \rightarrow \text { C. }}{c}$

URANIUM: DNC I

$4.90 \quad 0.0317$

$6.95 \quad 0.0373$

$\begin{array}{ll}5.79 & 0.0344 \\ 5.23 & 0.0327\end{array}$

0.060 .0351

$\begin{array}{ll}5.55 & 0.0337\end{array}$

$3.49 \quad 0.0269$

$\begin{array}{ll}3.21 & 0.0258\end{array}$

3.960 .0586

$5 ., 050.0553$

3.550 .7275

3.510 .0269

2. 490.0228

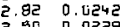

1.650 .0108

द. 37 0.0244

2. $67 \quad 0.0244$

1.680 .0189

$\begin{array}{lll}1.34 & 0.0222 \\ 3.14 & 0.0292\end{array}$

2.25 0.0218

2.56 0.0231

$\begin{array}{lll}2.69 & 0.0237\end{array}$

2.71 0.0238

2.44 $\quad 0.0226$

i. 610.0185

3.400 .0255

4.400 .0157

$1.60 \quad 0.0185$

$\begin{array}{ll}1.70 & 0.0191 \\ 0.89 & 0.0142\end{array}$

$\begin{array}{ll}0.89 & 0.0142 \\ 9.43 & 0.01+37\end{array}$

$\begin{array}{ll}9.43 & 0.0437 \\ 3.25 & 0.0260\end{array}$

$\begin{array}{ll}2.69 & 0.0245\end{array}$

1.40 0.015

3.130 .0255

$\begin{array}{ll}3.13 & 0.0255 \\ 3.03 & 0.0251\end{array}$

$3.17 \quad 0.0256$

2.050 .024

2.15 0.0213

ट. 05 c.020

$\begin{array}{rl}2.93 & 0.0243 \\ 3.99 & 0.0245\end{array}$
THORIGMINAA:

ㄹ. $1.95 \quad 151$

22. $18 \quad 1.54$

25. $25 \quad 149$

25.52

15.4

9. 5

7.97

$\begin{array}{ll}7.51 & 6.86 \\ 0.51 & 0.97\end{array}$

12.14 1.1

$\begin{array}{rl}12.09 & 1.23 \\ 7.95 & 1.37\end{array}$

5.59 :. 56

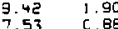

$7.89 \quad 1.06$

$3.07 \quad 1.48$

8. 82

6.05 :. 00

$\begin{array}{ll}7.05 & 6.97 \\ 5.94 & 1.05\end{array}$

$20.00 \quad 15$

-61
5.95

$\therefore .85$

3.58 c.

9. $95 \quad \therefore .18$

$4.96 \quad 1.20$

$13.36 \quad 38$

2. 00

5.62

$\begin{array}{rl}.54 & 1.25 \\ -5.57 & 2.92\end{array}$

6.5

$\begin{array}{ll}9.67 & 1.26 \\ 9.03 & 1.22\end{array}$ 
$5 I$

TAELE $8-1$. SEDIMENT ANALYSIS; ORY AND STREAM SITES

THOR I UNA + HEA I

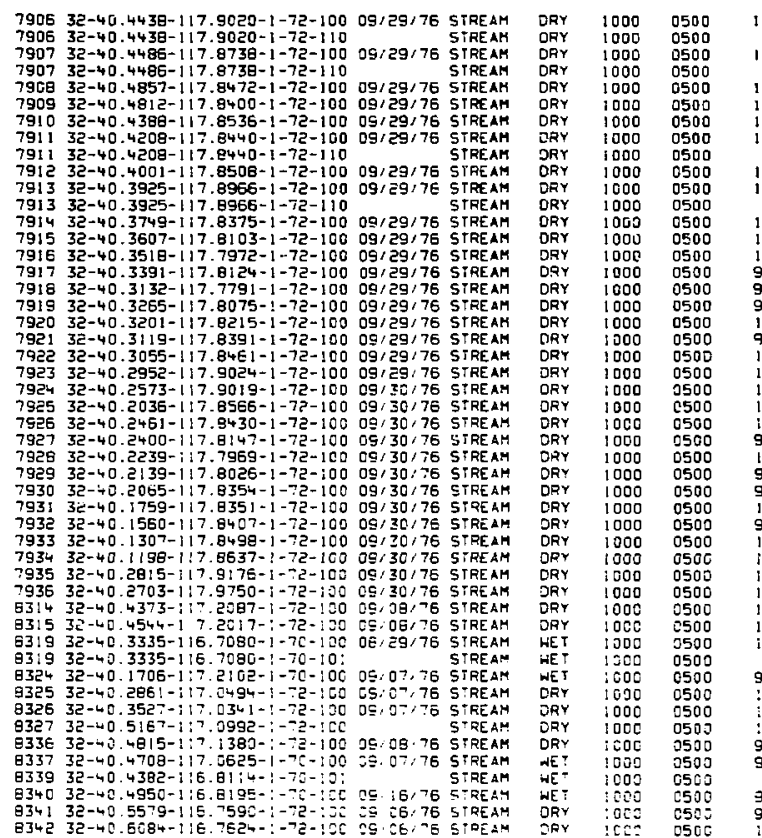

O. C. URANIUMIONC:

$\begin{array}{ll}e .52 & 0.0230 \\ 2.78 & 0.024^{\circ}\end{array}$

$\begin{array}{ll}2.78 & 0.024 \\ 3.53 & 0.0270\end{array}$

3.490 .0269

$3.28 \quad 0.0261$

$3.43 \quad 0.02 \$ 6$

2. 910.0246

2.59 0.0233

3.850 .0282

2.08 0.0209

$\begin{array}{lll}1.98 & 0.0205\end{array}$

$\begin{array}{ll}2.53 & 0.0230\end{array}$

5.84 0.0543

5.55 0.0231

6.09 0.035

2.26 0.0218

2.11 0.0211

$\begin{array}{ll}1.51 & 0.0185\end{array}$

2.4 0.025

$\begin{array}{ll}5.85 & 0.0214 \\ 3.50 & 0.0273\end{array}$

3.380 .025

5. $50 \quad 0.0259$

0.740 .0421

2.970 .0248

9.97
1.89
1.0 .0200

2.550 .023 .

2.560 .023

2.36 0.0222

$\begin{array}{ll}2.72 & 0.0238\end{array}$

$\begin{array}{lll}2.78 & 0.024\end{array}$

$\begin{array}{ll}3.67 & 0.0275\end{array}$

6927

$9.25 \quad 0.0433$

2.94 0.054 ?

$\begin{array}{lll}3.72 & 0.0277\end{array}$

$4.13 \quad 0.0291$

$5.07 \quad 0.032$

3. 980.0285

3.190 .6257

प.

$4.23 \quad 0.0295$

4.130 .0292

3.500 .0255

$\begin{array}{ll}3.50 & 0.0265 \\ 3.7 & 0.0277\end{array}$

3.070 .0253
$+59 \quad 094$

$9.15 \div 32$

9.26
7.93
1.30

$8.54 \quad 0.77$

\begin{tabular}{l|l}
8.27 & 1.51 \\
6.07 & 1.25
\end{tabular}

$\begin{array}{ll}5.64 & 0.89 \\ 5.90 & 1.59\end{array}$

8. 83 1.

B. 49

$\begin{array}{ll}4.92 & 1.5\end{array}$

5.48

$5.48 \quad G .8$

9.62

$9.41 \quad 1.68$

5. 010.65

$15.24 \quad 3.56$

5.07 1.43

9. 76 c. 92

9. 33

$11.41 \quad 1.35$

12.05

$4.47 \quad: .35$

12.85 i.z

9.951 .20

19.89

$117: \quad 1.20$

$\begin{array}{rl}\text { 8. } 55 & 1.61 \\ \text { i. } 09 & 1.52\end{array}$

ह $95 \quad 1.12$

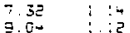

5. 76 

SITE
NUMBER ST LAT. LONG. LOY RPL MO-DA-YR SOURCE/CO $034332-40.5822-116.7565-1-72-100$ 09/05/76 5TREAM $1972332-40.7631-116.6694-1-72-10007 / 17 / 77$ STREAM $1972532-40.6851-116.5300-1-72-10007117177$ STREAM 9756 32-40.9111-116 5040-1-72-100 07117-77 5TREAM $1972732-40.0959-116.5160-1-72-10007 \times 17,77$ STREAM 19728 32-40.4日1-116.0974-1-72-100 071 1937 STREAM 5723 32-40 $4735-116.0831-1-72-10007+1837$ STREAM $1973032-40.4535-116.3535-1-72-100071,8 / 77$ STREAM $1973132-40.4391-116.0721-1-72-10007 / 18: 77$ 5TPEAM 9732 32-40.4310-116.0675-1-70-100 07/18/77 STREAM $1973332-40.4185-116.0783-1-72-100$ 07/18/77 5TREAM $1973432-40.4031-116.0773-1-72-10007118 / 77$ 5TREAH $1973532-40.3959-116.0785-1=72-10007 / 19 / 77$ STREAM $1973632-40.3742-116.0694-1-72-10007 / 19 / 77$ STREAM $1973732-40.3641-116.0413-1-70-10007 / 19 / 77$ STREAM $1933932-40.3044=116.0151-1-72-100071,19 / 77$ STREAM $1974032-40.5250-116.5844-1-72-10007 / 20 / 77$ STREAM $974132-40.5098-116.6140-1-72-100$ 07/20/77 5TREAM $1974232-40.4999-116.6117-1-72-10007 / 20 / 77$ STREAH $1974332-40.5279-116.6492-1-72-100$ 07/20/77 STREAM 19744 32-40.5135-116.6589-1-72-100 07/20/77 STREAH $974532-40.5478-116.6693-1-72-10007 / 20 / 77$ 5TREAM $1974632-40.5747-116.6479-1-72-100$ 07/21/77 STREAM $1974732=40.5837-116.6266-1-72-100$ 07/21/77 5TREAM 9748 $32=40.5954-116.6254-1-72-10007 / 21 / 77$ 5TREAM $1974932-40.5930-116.6372-1-72-10007 / 2: 177$ STREAM STREAM $1975132-40.7445-117.1893-1-72-10007 / 26 / 77$ STREAM 1975 e $32-40.7364-117.1919-1-72-10007 / 25 / 77$ STREAH $1975332-40.7328-117,1954-1-72-10007 / 26 r 77$ 5TREAM 19754 32-40.E436-117.1679-!-72-100 07/26/77 5roEAT 19755 32-40.6374-117, 13:3-1-72-100 07/26/77 STREAM 19757 32-40.6374-117.13:3-1-72-100 07/26/77 STREAM $1975832-40.703-1: 7657-:-72-10007 / 26,77$ SIREAH 9759 32-40 7:03-17 1586-i-72-100 07,26,77 5TPEAM $976032-40.7319-117.6692-1-72-15007 / 26 / 77$ STREAM 976: 32-40 7076- 117 i $492-1-72-10007,26,77$ SIREAH $976232-40,7165-117,1421-1-72-10007 / 26,77$ STREAM

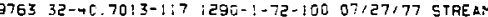
$1976432-47077-1: 11: 3-1-72-10007,27,77$ STREAM 15765 32-4 $0.6924-1: 7.0970-1-72-10007,27,77$ STREAH

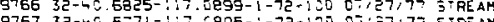

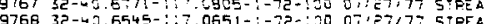
$1975932-0.6376-117-0430-1-72-3000727,77$ 5TREAM PIRTICLE SIZE POS.

DRY 1000

GRY 1000

DRY 1000

DRY 1000

DRY 1000

DRY 1000

DRY 1000

ORY 1000

$\begin{array}{ll}\text { WET } & 1000 \\ \text { DRY } & 1000\end{array}$

DRY 1000

ORY 1000

WRY 1000

OAY 1000

oAY 100

ORY 1000

DRY 1000

DRY 1000

DRY 1000

DRY

DRY

ORY

ORY

DRY 1000

MRY 1000

DR.

DRY

DRY

DRY

DRY

ORY

DRY IOAY

$\begin{array}{ll}\text { DRY } & 1000 \\ \text { DRY } & 1000\end{array}$

DRY 1000

DRY 1000

$\begin{array}{ll}\text { DRY } & 1000 \\ \text { DRY } & 1000\end{array}$

DPY o e URANILMIONC:

6967$$
0500
$$$$
0500
$$$$
0500
$$

IHOR IUH (NAA)

7.29 1.01

$\begin{array}{ll}3.22 & 0.0250 \\ 1.41 & 0.0175\end{array}$

$5.50 \quad 0.0335$

$4.70 \quad 2.03 i 0$

4.940 .0318

$3.62 \quad 0.0273$

$3.09 \quad 0.0253$

3.820 .0280

. 000.0196

2. $64 \quad 0.0035$

$\begin{array}{lll}2 & 36 & 0.0223 \\ 3.46 & 0.026\end{array}$

.710 .031

3.67 0.0275

$3.86 \quad 0.0282$

4. $36 \quad 0.0239$

$4.30 \quad 0.0285$

3.25 a.0206

1.720 .0192

2. $80 \quad 0.0242$

$1.47 \quad 0.0178$

$\begin{array}{ll}3.37 & 0.0254 \\ .00 & 0.0233\end{array}$

2.84 0.0243

$\begin{array}{ll}\text { 2. } 35 & 0.0217 \\ 2.28 & 0.0219\end{array}$

3.190 .0257

3. $08 \quad 0.0253$

$\begin{array}{ll}3.37 & 0.0264 \\ 3.56 & 0.0271\end{array}$

$\begin{array}{ll}3.56 & 0.027 \\ 3.53 & 0.0270\end{array}$

-.5 0.0270

$\begin{array}{ll}3.53 & 0.0230 \\ 4.18 & 0.0293\end{array}$

$3.830 .028 \mathrm{i}$

$5.12 \quad 0.0324$

3.330 .0263

$\begin{array}{lll}3.57 & 0.0272\end{array}$

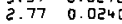

$\begin{array}{lll}3.57 & 0.0272\end{array}$

$\begin{array}{ll}2.55 & 0.023 \text { ? } \\ 4.62 & 0.0300\end{array}$
$25.50 \quad 1.75$

$15.64 \quad 1.92$

$5.95 \quad 0.9$

6. $3 \vec{r} \quad: .40$

$4.96 \quad 0.7$

6.020 .9

$10.72 \quad 1.00$

7.39

$0.52 \quad i .89$

1.3508

$17.10 \quad 1.79$

1.65

$5.32 \quad 1.48$

$10.87 \quad 1.58$

6.03

$\begin{array}{rl}6.05 & 1.25 \\ 1.31 & 1.32\end{array}$

$\begin{array}{ll}8.72 & 1.69 \\ 8.50 & 1.03\end{array}$

$\begin{array}{ll}0.05 & 1.35 \\ 9.43 & 1.10\end{array}$

$10.42 \quad 119$

13.48
7.99

9. 58 : 32

E. $05 \quad 1.0 .3$

E $55 \quad 097$

9. 19

C. 62

$9.43 \quad c .99$

$15.43 \quad 1 .: 16$

$10.10 \quad 1.05$ 


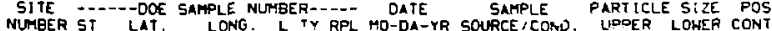

$1977132-40.6275-117.0733-1-72-10007 / 27 / 77$ STREAM $1977232-40.6185-117.0768-1-72-10007127,77$ STREAM $1977532-40.5635-117.0990-1-72-10007,27,77$ STREAH $1977632-40.5302-117.0862-1-72-100$ 07/20/77 STREAH $1977732-40.5860-117.1583-1-70-10007 / 28 / 77$ STREAM
19776 32-40.5535-117.2055-1-72-100 07/29,77 STREAM $1977632-40.5535-117.2055-1-72-10007 / 29 / 77$ STREAM
$1977932-40.5462-117.2232-1-72-10007 / 28 / 77$ STREAM 19700 32-40.5031-117.2375-1-72-100 07/28/77 STREAH $1978132-40.5750-117.2363-1-72-10007 / 28 / 77$ STREAM 1978 32-40.657-117.2317-1-72-100 07/28/77 5TREAM 19784 32-40.6318-117.2347-1-72-100 07.28 19705 32-40.630 19705 32-40.5131-117.0071-1-72-100 07.20,77 STPEAM $1978632-40.6131-117.0071-1-72-10007 / 29 / 77$ STPEAM $1994432-40.5700-116.5664-1-72-100$ 07? 16/77 STREAM 19945 32-40.5620-116.5948-1-72-100 07, 16:77 STREAM $1994632-40.9526-116.5093-1-72-10077 / 1 / 1 / 77$ STREAM 19947 32-40.9.5 198 32-40.9845-116.593-1-72-100 07,17/77 STREAM 13950 32-4c.9:20 116.0232-1-72-100 07,17/77 5TREAM .9951 3e-40.9794-116.6772-1-72-100 J71,7/77 STREAM $1995232-40.4687-116.1672-1-72-100$ 37/18:77 STREAM 19953 32-40.43E3-116.1800-1-72-100 37/18/77 5TREAM 19954 32-40.4155-116.1620-1-72-100 07/18/77 STREAM 19555 32-40.4000-116.16/0-1-72-100 37/:8/77 STREAM

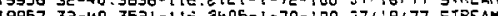
1997 32-40.35e1-1.5.2405-1-70-100 37,

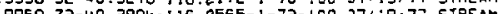

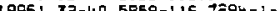
19962 32-40.5362-116. $1372-1-72-10037$ on, 77 STAEAM $1006332-40.6577-116.6842-1-72-10037120177$ STREAT 19964 32-40.6504-115 55-6-1-72-100 37/20/77 5TREAM 19955 32-40.6888-116-5574-1-72-100 37/20177 5TR5AM 19966 32- $40.5950-1165195-1-72-100$ J7120 77 5IFEAM $1996732-40.5365-1: 6.5364-:-72-: 00$ 57'2:,77 STREAS

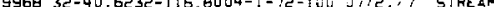
19969 3ट-40.6.95-116.5850-1-7e-100 J7: 19536 32-40.6323-116-6303-i-7e-100 38:j9.79 STREAM $2053632-40.0798-115$ $2053932-40.1439-11$ $2054032-40.1152-115.6397-1-72-10028.09 \%$ STREAM $2054032-40.1152-116.6397-1-72-11003090,7$ STREAH

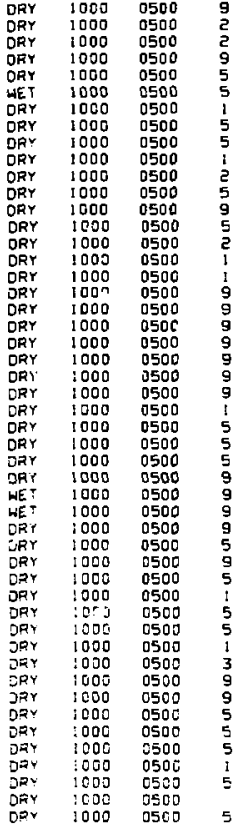

Q.
$X \rightarrow$ REF URANIUMIONCI
PPM ERR

$3.33 \quad 0.0263$

$3.33 \quad 0.0263$ 16.88
15.25 15.25
11.70 7.44 11.20

3.160 .0256

$3.06 \quad 0.0252$ 3.020 .0251 $\begin{array}{ll}3.30 & 0.0250 \\ 3.35 & 0.02 E 1\end{array}$ $\begin{array}{ll}3.32 & 0.0221 \\ 3.42 & 0.0225\end{array}$ $3.36 \quad 0.0264$ $\begin{array}{lll}3.74 & 0.0239\end{array}$ $\begin{array}{ll}2.25 & 0.0217\end{array}$

2.770 .0240

$4.34 \quad 0.0298$

$3.48 \quad 0.0268$ 2.90 0.0245 $3.03 \quad 0.0251$

$3.65 \quad 0.0274$

$4.17 \quad 0.0293$

3.00 0.0250

3.310 .0262

$4.92 \quad 0.0317$

$\begin{array}{ll}5.03 & 0.0321 \\ 4.58 & 0.0306\end{array}$

3.410 .0266

$4.14 \quad 0.0292$

4.270 .0296

4.430 .0302

2.62 0.024

2. $06 \quad 0.0245$

1.620 .0166

$\begin{array}{ll}.52 & 0.0232\end{array}$

2. $10 \quad 0.0211$

0.340 .0095

4.510 .0304

$3.65 \quad 0.0274$

$5.36 \quad 0.033 !$

$4.86 \quad 0.0316$

4.690 .0310

$3.78 \quad 0.0279$

$3.62 \quad 0.0273$

[.. $05 \quad 0.0493$

$\begin{array}{ll}4.58 & 0.0306\end{array}$
6.34 1.18

$\begin{array}{ll}9.76 & 1.36 \\ 7.98 & 0.91\end{array}$

$14.99 \quad 1.34$

$\begin{array}{ll}9.81 & 0.96 \\ 4.45 & 0.88\end{array}$

4.45
A.
12.

$14.99 \quad 1.34$

$11.97 \quad 1.46$

$16.83 \quad 136$

$\begin{array}{ll}6.29 & 69 \\ 8.25 & . .23\end{array}$

$19.42 \quad 1.65$

$10.40 \quad 1.94$

11.

14.91

16.50

15.02

12. 15

11.24

3.56

6.17
5.54

1 E. 72

8.60
19.47

18.93

19.89

20.9C

7.92

9.23
17.55

11.94

46
55
36
69
23
65
94
01
14

1.14

1.45

1.38

1. 36

1.28
1.27

1.02

1. 32

1.62

i. 58

1.64
1.03

0.79

1. 99

1. 26
.36

.33 . 8 1 .41 
SITE -...-DOE SAMPLE NUMEER-... DATE SAMPLE PARTICLE SIZE POS.

20542 32-40.0414-116.6577-1-72-100 08/09/77 STREAM $2054335-40.0270-116.6590-1-72-10008709777$ STREAH $20 \$ 53$ 32-40.004B-116.7903-1-72-100 08/09/77 STREAM 20554 32-4c.0030-116.7903-1-72-100 08/09/77 STREAM 20555 32-40.0093-115.7950-1-72-100 08/09/77 5TREAM $2953832-40.0382-117.9076-1-72-10008.401$ $2953932-40.0174-117.8261-1-72-10008 / 16 / 77$ STREAM $2954032-4 \mathrm{C} .0011-117.6306-1-72-10008 / 16 / 77$ STREAM 2954 32-40.0654-11?.7855-1-7e-100 08/16 作 (1) (1) (4) (100 29549 32-40.1095-117.6301-1-72-100 08/17/77 5TREAM $2955032-40.1340-117.6162-1-72-10008 / 17 / 77$ STREAM $2955232-40.0883-117.7202-1-72-10008 / 16 / 77$ STREAT 29553 32-40.0947-117.7097-1-72-100 08/16/77 STREAM $2955432-40.1472-117.6715-1-72-10008 / 16 / 77$ STREAM 29555 32-40.1553-117.6775-1-72-100 08/16/77 5TREAM $2955632-40.1225-117.5797-1-72-10008117 / 77$ STREAM $2555732-40.1406-117.5646-1-72-100081 \div 7177$ STREAM $295832-40.1568-117.5495-1-72-300$ 08/17777 STREAM $2955932-40.1623-117.5450-1-72-10008117 / 77$ STREAH 29kE: $32-40.2029-117.5264-1-72-100$ 08, 17,77 STREAM 2956 32-40.2029-117.5264-1-72-100 08/17/77 STREAM $3956332-40.2409-11774014-1-72-1000811777$ 5TREAM 32-40. $409-117.4979-1-72-100$ 09/17/77 5TREAM 32555 32-40.2330-117.4326-1-72-100 09117177 5TREAM $2956632-40.2320-117.4596-1-72-10009 / 17 / 77$ STREAM

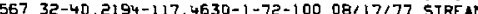
29568 32-40.1995-117.4723-1-72-100 08/17/77 STREAH $2956932-40.1853-117.4710-1-72-10008 / 17 / 77$ STREAM 29570 32-40.1662-117.4721-1-70-100 08/17/77 STREAM $2957132-40.1535-117.4965-1-72-10008 / 17 / 77$ STREAM $2957232-40,1085-117,483+1-72-10008 / 17 / 77$ STREAM $2957332-40.1031-117.4834-1-72-100$ 08/17/77 STREAH 29574 32-40.0914-117.4845-1-72-100 08/17/77 5IFEAH $2957532-40.0797-117.4727-1-72-10008 / 17177$ 5TREAM 295.5 32-40.0833-117.4795-1-72-100 38/17177 STREAM 29577 32-40.139i-1.7.4948-1-72-100 08/17/77 STREAP 29578 $32-40.1254-179.536-i-72-100$ U8 17777 STREAM $3950: 32-40.0975-117.53 \geq 6-1-72-10008117,77$ 5:PEAM

\begin{tabular}{|c|c|c|}
\hline $\begin{array}{l}\text { ORY } \\
\text { DRY } \\
D R Y \\
\text { DRY } \\
\text { CRY } \\
\text { ORY } \\
\text { DRY } \\
\text { CRY } \\
\text { ORY } \\
\text { ORY } \\
\text { DRY } \\
\text { ORY } \\
\text { DRY } \\
\text { DRY } \\
\text { ORY } \\
\text { DRY } \\
\text { DRY } \\
\text { DRY } \\
\text { ORY } \\
\text { DRY } \\
\text { DRY }\end{array}$ & $\begin{array}{l}1000 \\
1090 \\
1000 \\
1000 \\
1000 \\
1000 \\
1000 \\
1000 \\
1000 \\
1000 \\
1000 \\
1000 \\
1000 \\
1000 \\
1000 \\
1000 \\
1000 \\
1000 \\
1000 \\
1000 \\
1000 \\
1000 \\
1000 \\
1000 \\
1050 \\
1000 \\
1000 \\
1000 \\
1000 \\
1000 \\
1000 \\
1000 \\
1000 \\
1000 \\
1000 \\
1000 \\
1000 \\
1000 \\
1000 \\
1000 \\
1000 \\
1000 \\
1060 \\
1000 \\
1000 \\
1000 \\
1000 \\
1000 \\
1000\end{array}$ & $\begin{array}{l}0500 \\
0500 \\
0500 \\
0500 \\
0500 \\
0500 \\
0500 \\
0500 \\
0500 \\
0500 \\
0500 \\
0500 \\
0500 \\
0500 \\
0500 \\
0500 \\
0500 \\
0500 \\
0500 \\
0500 \\
0500 \\
0500 \\
0500 \\
0500 \\
0500 \\
0500 \\
0500 \\
0500 \\
0500 \\
0500 \\
0500 \\
0500 \\
0500 \\
0500 \\
0500 \\
0500 \\
0500 \\
0500 \\
0500 \\
0500 \\
0500 \\
0500 \\
0500 \\
0500 \\
0500 \\
0500 \\
0500 \\
0500 \\
0500\end{array}$ \\
\hline
\end{tabular}

Q. C. URA:"'UMIDNCI
X-REF PPH ERR

$\begin{array}{rr}4.35 \quad 0.0299 \\ 3.71 & 0.0276\end{array}$

$\begin{array}{lll}3.71 & 0.0276\end{array}$

$\begin{array}{ll}4.27 & 0.0296\end{array}$

$\begin{array}{ll}4.24 & 0.0295 \\ 4.07 & 0.0209\end{array}$

5.050 .0321

$4.02 \quad 0.0268$

$\begin{array}{rl}.76 & 0.0194 \\ 1.56 & 0.0204\end{array}$

$3.37 \quad 0.0264$

2.470 .0228

3.30 0.0255

$5.67 \quad 0.0275$

$\begin{array}{lll}3.99 & 0.0249\end{array}$

$\begin{array}{ll}3.61 & 0.0273 \\ 3.69 & 0.0276 \\ 4.42 & 0.0301\end{array}$

$4.42 \quad 0.0301$

$1.48 \quad 0.0178$

$\begin{array}{ll}2.95 & 0.0248\end{array}$

$\begin{array}{ll}3.99 & 0.0249 \\ 3.32 & 0.0265\end{array}$

$\begin{array}{rl}3.32 & 0.0262 \\ 4.09 & 0.0290\end{array}$

$\begin{array}{ll}4.51 & 0.0304\end{array}$

$\begin{array}{ll}4.31 & 0.0297 \\ 3.89 & 0.0293\end{array}$

$\begin{array}{ll}3.89 & 0.0283 \\ 5.20 & 0.0326\end{array}$

$\begin{array}{ll}5.56 & 0.0326 \\ 3.65 & 0.0275\end{array}$

उ. 06 0.0282

$3.58 \quad 0.0272$

4.370 .0300

$5.90 \quad 0.0347$

3.510 .0269

$4.54 \quad 0.0308$

$\begin{array}{rl}3.16 & 0.0256 \\ 4.99 & 0.0320\end{array}$

$11.10 \quad 0.0474$

5. $85 \quad 0.0346$

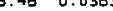

$\begin{array}{lll}0.46 & 0.041^{2}\end{array}$

$398 \quad 0.0286$

4.410 .0301

6.410 .036

$\begin{array}{ll}3.82 & 0.0281 \\ 4.65 & 0.0309\end{array}$
PHORIUM (NAA)

$\begin{array}{rr}7.79 & 0.76 \\ 10.04 & 1.06\end{array}$

6. $97 \quad 1.02$

10.20
$17.60 \quad 1.14$

$13.37 \quad 1.81$

$\begin{array}{ll}2.72 & 0.80 \\ 4.65 & 1.09\end{array}$

$11.65 \quad 1.11$

$\begin{array}{ll}11.95 & 3.93 \\ 7.65 & 3.76\end{array}$

$12.69 \quad 1.41$

$14.55 \quad 1.37$

8.42 0.75

$13.28 \div .69$

$13.11 \quad 0.31$

5.70
11.85

$11.52 \quad 1.12$

$13.62 \quad 1.20$

$16.5 ! \quad 1.43$

9.60
15.55

$21.77 \quad 1.73$

$\begin{array}{ll}0.53 & 0.78\end{array}$

14.18 1.2.

$14.28 \quad 1.41$

$14.43 \quad 1.59$

$16.88 \quad 1.51$

$20.53 \quad 1.45$

$\begin{array}{ll}19.48 & 1.91 \\ 21.79 & 1.7\end{array}$

$26.58 \quad=.05$

20.90 1.75

$\begin{array}{ll}31.81 & 2.23 \\ 18.37 & 1.39\end{array}$

$15.57 \quad 1.48$

$24.94 \quad 1.9$

15.31 


\section{SITE} ST LAT.
LAT

HPLE MUMBER-

DATE

SATPLE

PARTICLE SIZE POS.

Q. C.

UARANIUAIONC)

THOR! UMI INAA)

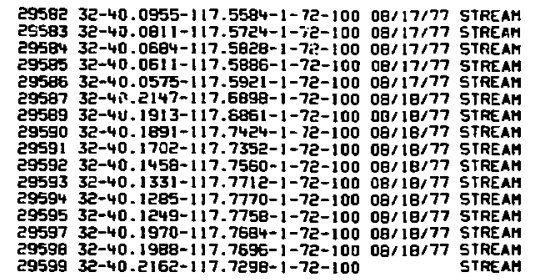

$\begin{array}{llll}\text { DRY } & 1000 & 0500 & 1 \\ \text { DRY } & 1000 & 0500 & 1 \\ \text { DRY } & 1000 & 0500 & 1 \\ \text { DRY } & 1000 & 0500 & 1 \\ \text { DRY } & 1000 & 0500 & 1 \\ \text { DRY } & 1000 & 0500 & 5 \\ \text { DRY } & 1000 & 0500 & 1 \\ \text { DRY } & 1000 & 0500 & 1 \\ \text { DRY } & 1000 & 0500 & 1 \\ \text { DRY } & 1000 & 0500 & 1 \\ \text { DRY } & 1000 & 0500 & 1 \\ \text { DRY } & 1000 & 0500 & 1 \\ \text { DRY } & 1000 & 0500 & : \\ \text { DRY } & 1000 & 0500 & 1 \\ \text { DRY } & 1000 & 0500 & : \\ \text { DRY } & 1000 & 0500 & 1\end{array}$

PPH

PPM

DRY IOOD

$\begin{array}{rrrr}4.24 & 0.0295 & 13.92 & 1.11 \\ 4.06 & 0.0289 & 12.22 & 1.08 \\ 5.68 & 0.0341 & 7.33 & 0.89 \\ 4.10 & 0.0291 & \mathbf{7 . 3 0} & 0.82 \\ 3.21 & \mathbf{0 . 0 2 5 8} & 9.21 & 0.93 \\ 4.04 & \mathbf{3 . 0 2 8 9} & 14.73 & 1.49 \\ 2.67 & \mathbf{0 . 0 2 3 6} & 10.31 & 1.20 \\ 1.89 & 0.0201 & 8.25 & 1.09 \\ 1.44 & \mathbf{0 . 0 1 7 7} & \mathbf{5 . 2 6} & \mathbf{0 . 9 7} \\ 2.81 & \mathbf{0 . 0 2 4 2} & \mathbf{8 . 8 3} & 1.43 \\ 2.90 & \mathbf{0 . 0 2 4 6} & & \\ 3.06 & \mathbf{0 . 0 2 5 2} & 9.32 & 0.92 \\ \mathbf{3 . 2 1} & \mathbf{0 . 0 2 5 8} & 10.30 & 0.97 \\ 2.74 & \mathbf{0 . 0 2 3 9} & 9.94 & 1.12 \\ 2.93 & \mathbf{0 . 0 2 4 7} & 10.02 & \mathbf{1 . 0 2} \\ \mathbf{4 . 2 9} & \mathbf{0 . 0 2 9 7} & 16.74 & 1.58\end{array}$




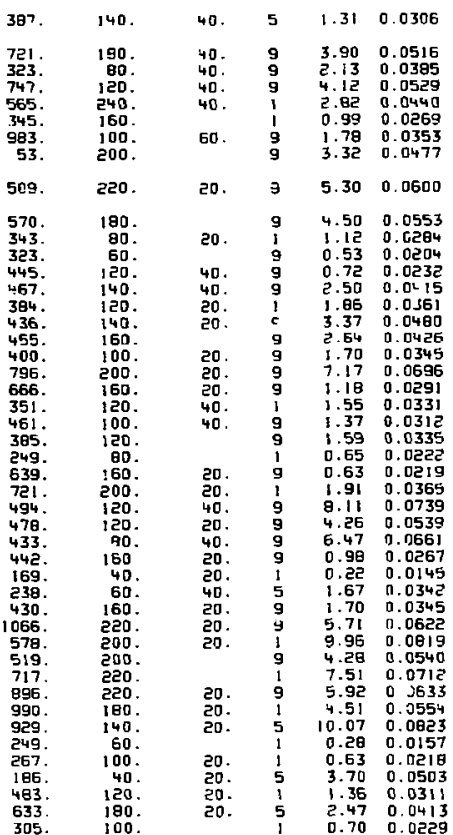


SITE --.--DOE SAMPLE NUMBER-..--
DATE LONG. L TY RPL MO-DA-YH SOURCE
TEKP PH SPEC COND AKTOTL AHOHEN POS

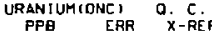

55B $32-40.9020-117.6969-1-22-200 \quad 09 / 13 / 76$ STREAM $13.8 \quad 8.4$ 5584 32-40.8127-117.7126-1-22-200 09/13/76 STREAM 23.7 $558632-40.7302-117.6596-1-22-200$ 09/13/76 STREAH 23.8 8.6 $558 \mathrm{~B} 2-40.9040-117.9225-1-22-20009 / 13 / 76$ STREAH 23.09 .4 $559432-40.8484-117.8933-1-22-20009 / 14 / 76$ STREAM $11.7 \quad 7.7$ $585932-40.6011-117.9502-1-22-20009 / 19 / 76$ STREAH 11.05 .7 6222 32-40.3279-116.4279- $1-22-20000 / 03 / 76$ STREAM 25.0 8.8 $622332-40.3805-116.3167-1-22-20008 / 03 / 76$ STREAH $14.0 \quad 8.3$ $627532-40.7050-116.5312-1-22-20003108 / 76$ SIREAM 24.09 .4 $627632-40.6606-116.7457-1-22-20000 / 08 / 76$ STREAM 23.0 0.2 6309 32-40.3609-116.0944-1-22-200 08/12/76 STREAH 13.08 .4 $634032-40.1715-117-2055-1-22-200$ 09, 5176 STREAH 21.0 9.4 $635232-40.3564-116.9929-1-22-20009 / 16 / 76$ STREAM $14.0 \quad 8.4$ 6353 32-40.322 $1-116.9906-1-22-200$ 09/17/7E SIREAT 10.0 8.1 6373 32-40.5258-117.4321-1-22-200 08/20/76 STREAH 19.0 9.5 $639232-40.6545-116.9196-1-22-200$ 00,23/76 STREAH $17.0 \quad 8.4$ $684232-40.3326-116.7104-1-22-20008 / 03 / 76$ SIREAH 11.58 .5 $664332-40.3421-116.3913-1-22-20000 / 03 / 76$ STREAH 18.0 B.6 $694732-40,3291-116.7552-1-22-20000 / 04 / 76$ STREAM 26.09 .3 $686032-40.5984-116.4741-1-22-20000 / 08 / 76$ STREAM 19.0 $686332-40.7403-116.3818-1-22-20000 / 08 / 76$ STREAM $27.0 \quad 8.6$ $687232-40.0066-116.1893-1-22-20000 / 09 / 76$ STREAM 17.58 .0 $669132-40.3232-116.1078-1-22-20000 / 12 / 76$ STREAM 18.5 B.5 6995 32-40.5011-!16.0535-1-22-200 09/12/76 STREAM 23.5 S.8 $693332-40.3248-1 ; 6.9141-1-22-20009 / 1776$ STREAM 9.07 .7

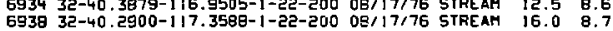
$693835-40.2900-117.3586-1-52-501$ STREAH 6957 $32-40.4302-116$ (1) $695932-40.4950-116.6195-1-22-200$ 09/22/76 STREAM $15.5 \quad 8.4$ $715332-40.4324-117.5671-1-22-200$ I0/04/76 STREAM 6.4 9.3 $715432-40.4534-117.5201-1-22-20010 / 04 / 76$ STREAM 7.59 .1 $715632-40.4858-117.5321-1-22-20010 / 04,76$ STREAM 13.18 .1 $715732-40.3458-117.6040-1-22-20010 / 04 / 76$ SIREAM 15.0 8.0 $715832-40.3215-117.5932-1-22-20010 / 04 / 76$ STREAM 13.68 .0 $715932-40.3163-117.5500-1-22-20010 / 04 / 76$ STREAM 17.2 8.6 $716032-40.3154-117.5496-1-22-20010 / 04 / 76$ SIREAM 10.0 9.7 $716132-40.5879-117.1560-1-22-20010 / 04 / 76$ STREAM 9.77 .5 $716232-40.5897-117.1572-1-22-20010 / 05 / 76$ SIREAM $7.5 \% 7.3$ $716432-40.4868-117.4543-1-22-20010 \% 05 / 76$ SIREAM 11.5 8.5 $716632-40.4771-117.4566-1-22-20010 / 05 / 76$ SIREAM 13.3 8.3

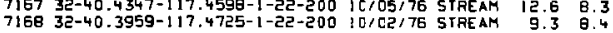

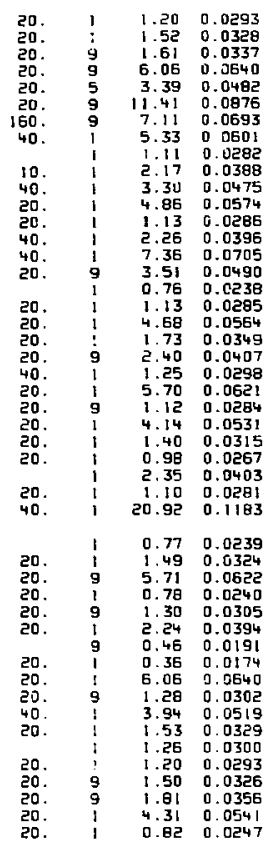




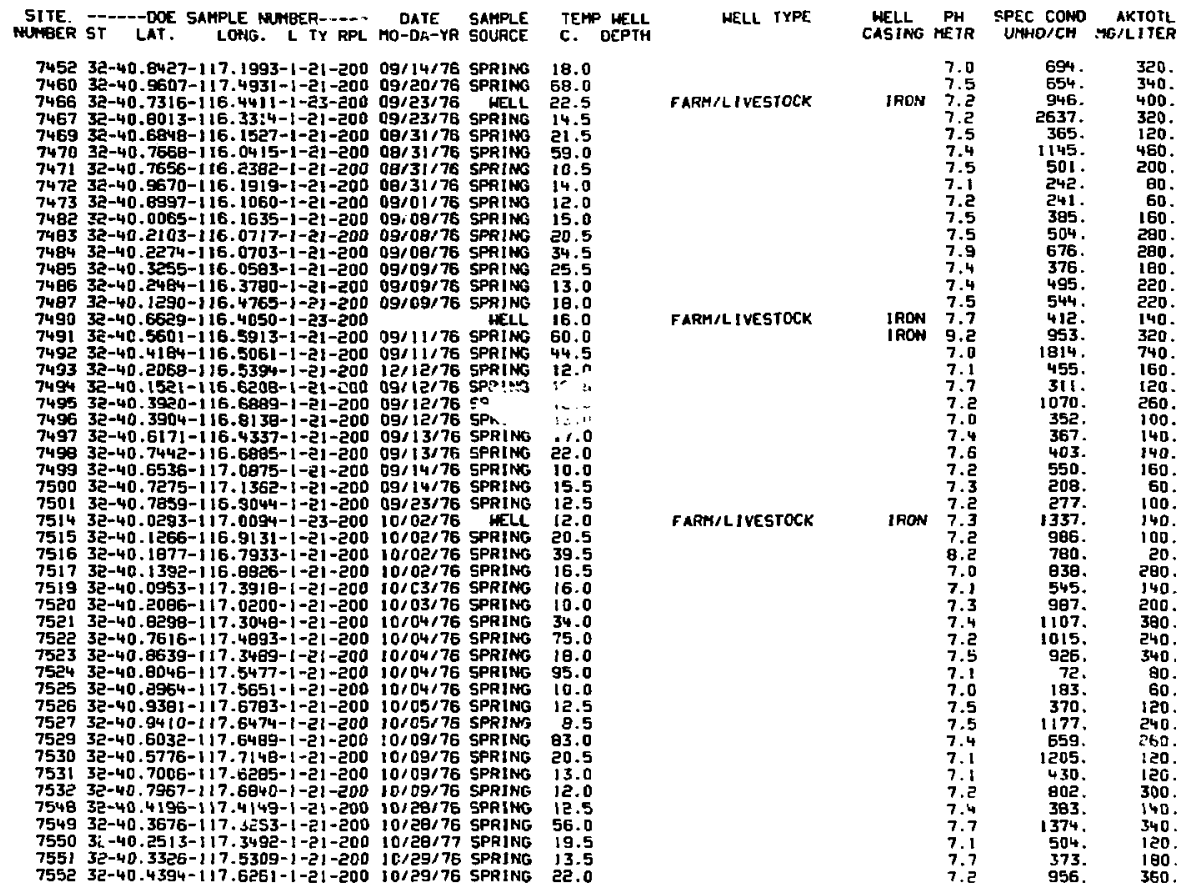




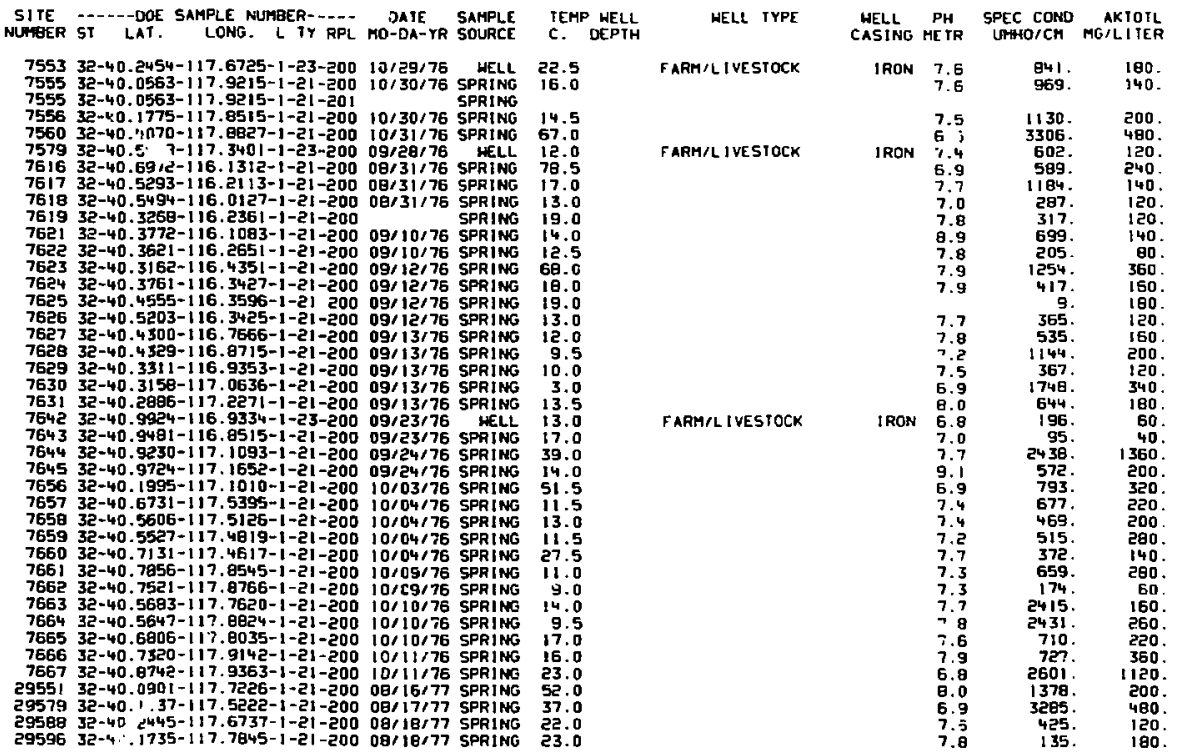


MITE MAPHEN POS. URANIUMIONCI, O. C.

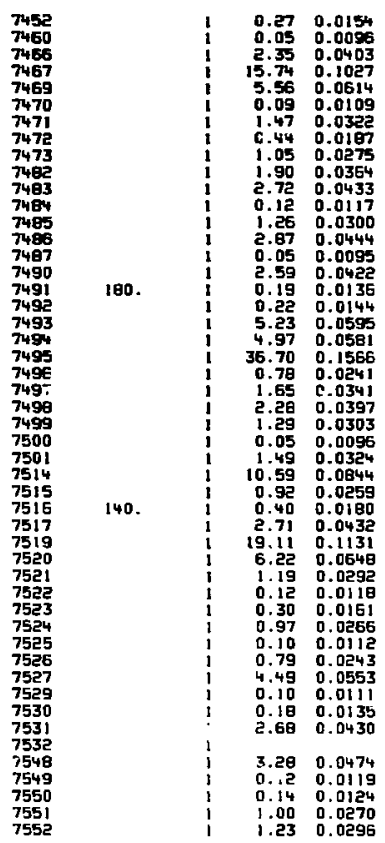




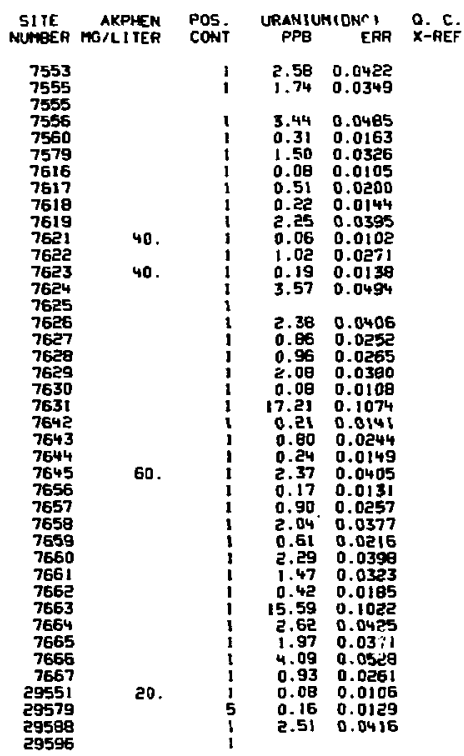




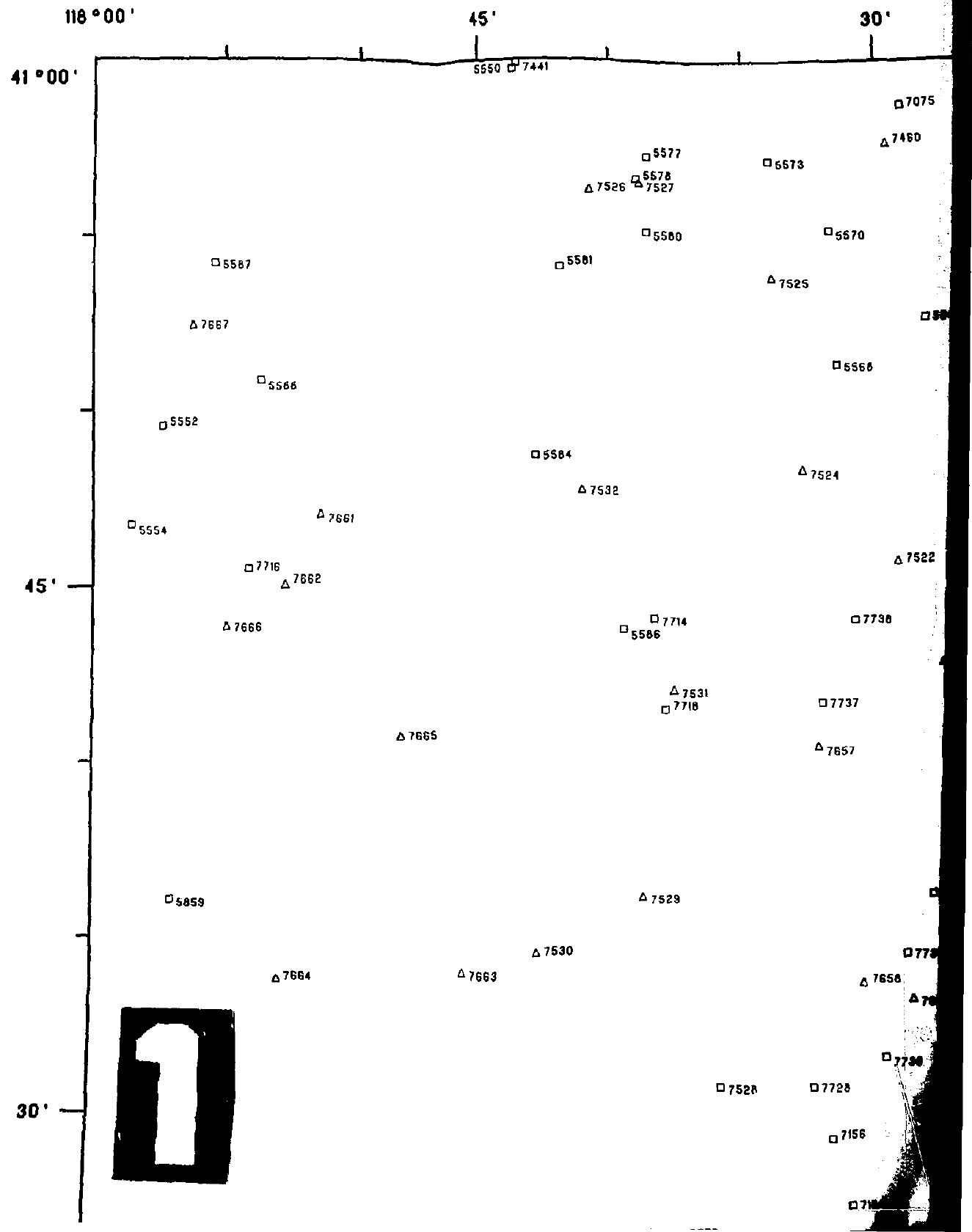




\section{प7711}

$\triangle 7644$
Q7704

D5549

$\Delta^{7523}$

$$
\Delta 7452
$$

$\Delta^{752 t}$

$\Delta 7660$
口7735

$\Delta_{7659}$

$\nabla_{7579}$

$D_{7730} \quad 764 \quad D_{0}^{6373}$

口 7195

口7198

$$
\Delta^{7500}
$$

$\Delta 7499$

$\square_{7808}$

$71620_{7161}$ 
NK 11-11
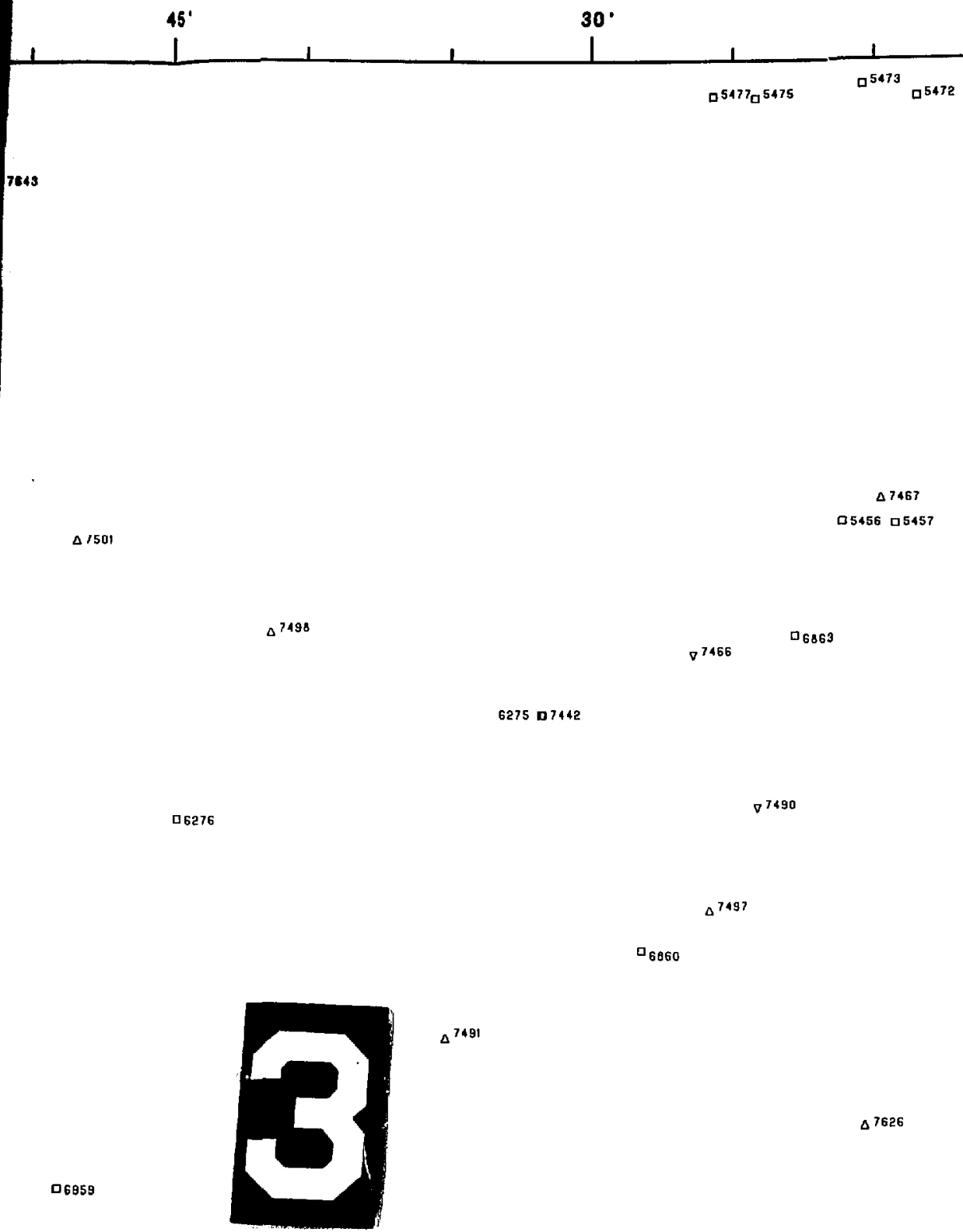

$$
\Delta^{7491}
$$


NK $\|-\|$
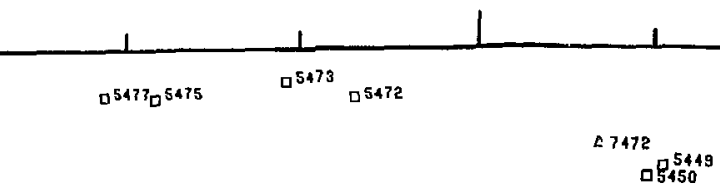

$\square_{5495}$

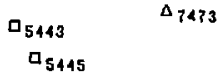

05441

$$
\begin{array}{r}
D_{5431} \\
\square 5442^{D_{5492}}
\end{array}
$$

$\triangle 7467$

$\square \$ 456 \quad 05457$

${ }_{\nabla 7666} \quad \square_{6663}$

$7471 \triangle \square 512 B$

$0^{5125}$

05522

$41^{\circ} 00^{\circ}$

D 5523

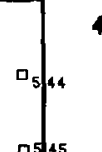

5396 7616

$\triangle 7469$

口5397

口 $515 s$

$\triangle 7470$

$45^{\prime}$

$\nabla 7490$

口5390

$\Delta^{749:}$

$\mathbf{0}_{6660}$

$\triangle 7626$ $\square^{554 S}$
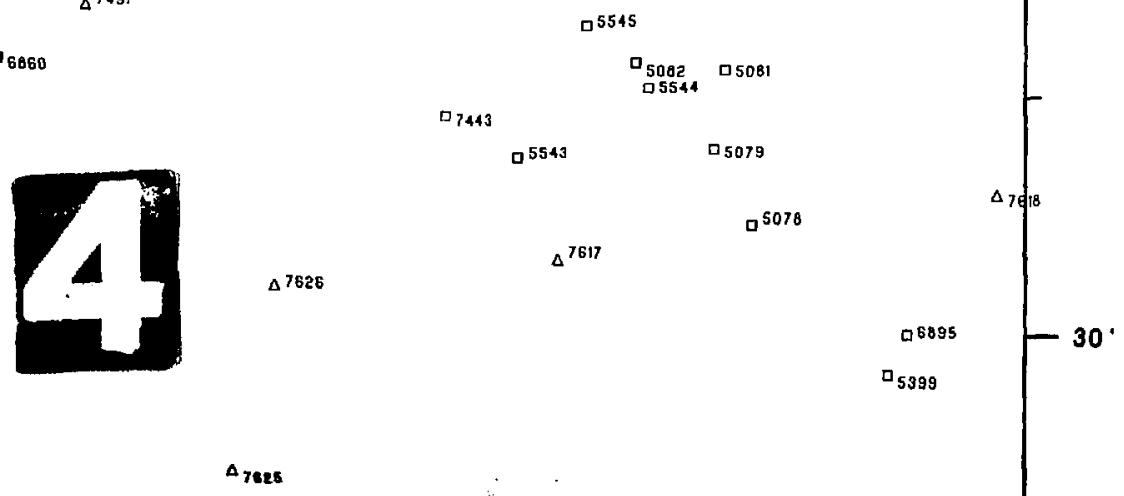

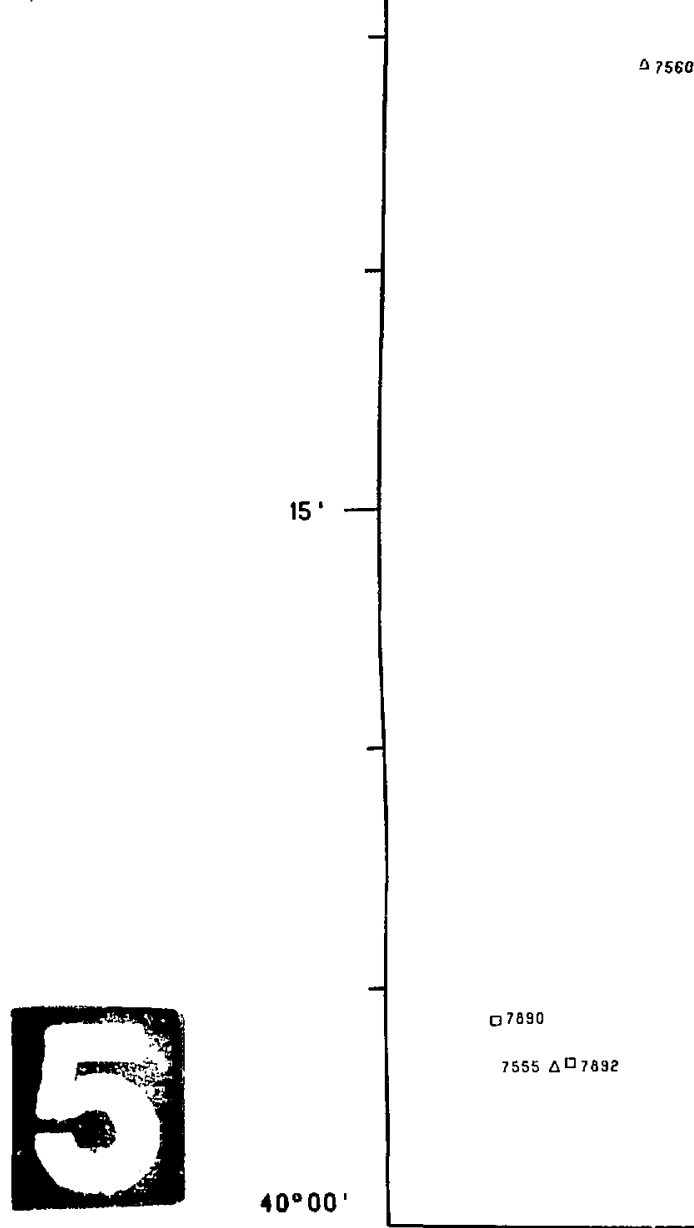

7555007002

LAWRENCE

LIVERMORE

LABORATORY

UNIVERSITY OF CALIFORNIA 
맏

ㅁ710

$\Delta 7551$

$59=7160$

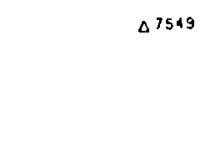

$\triangle 7549$

$7172-6938$

07173
$\Delta 7550$

01749

$\square 7754$

$\triangle_{7656}$

$0^{6340}$ $\triangle 7630$

06353

$\square 29570$

$\Delta^{29579}$

$\Delta 519 \quad \square 7757$

$\nabla^{7514}$

SITE LOCATIONS. WATE 


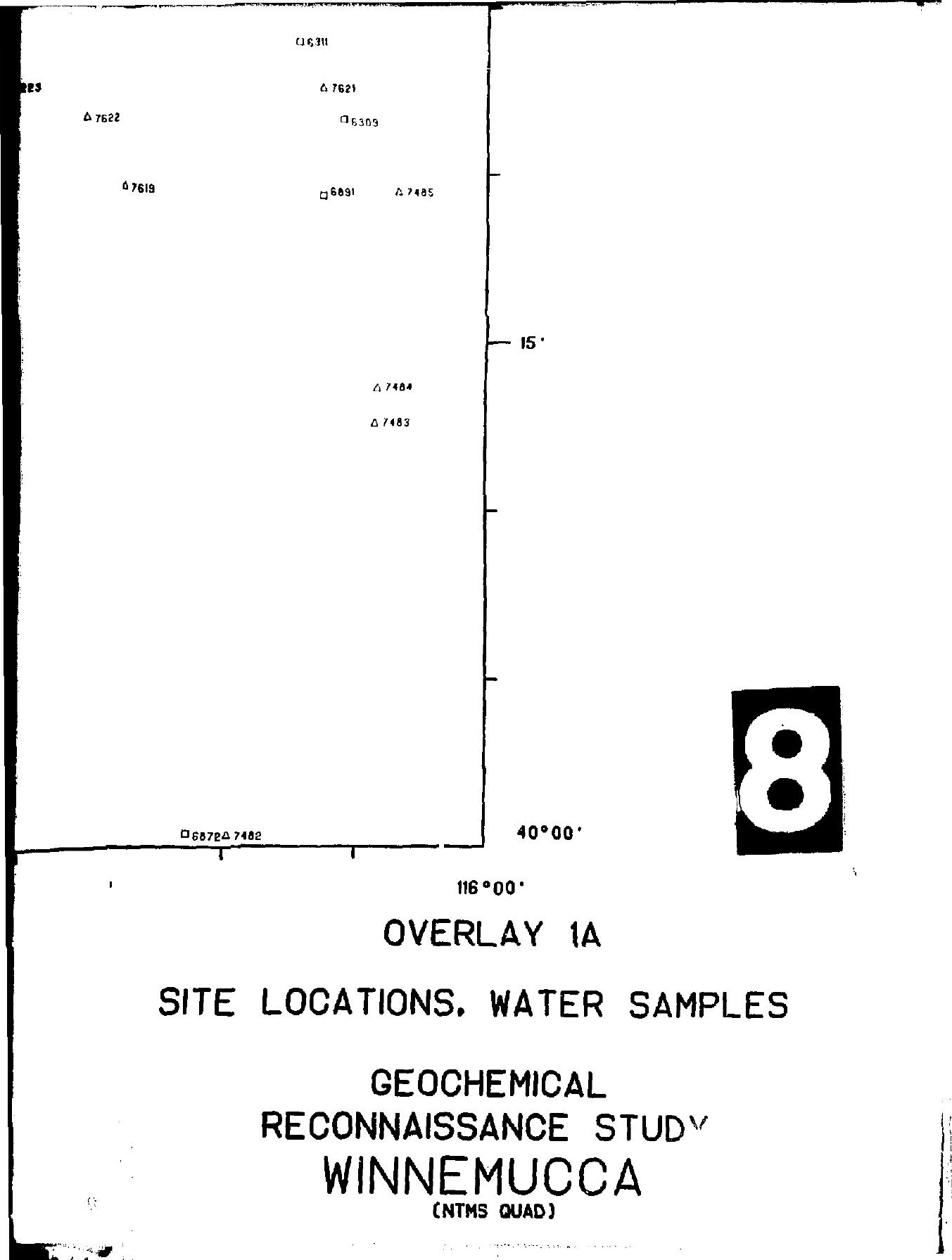




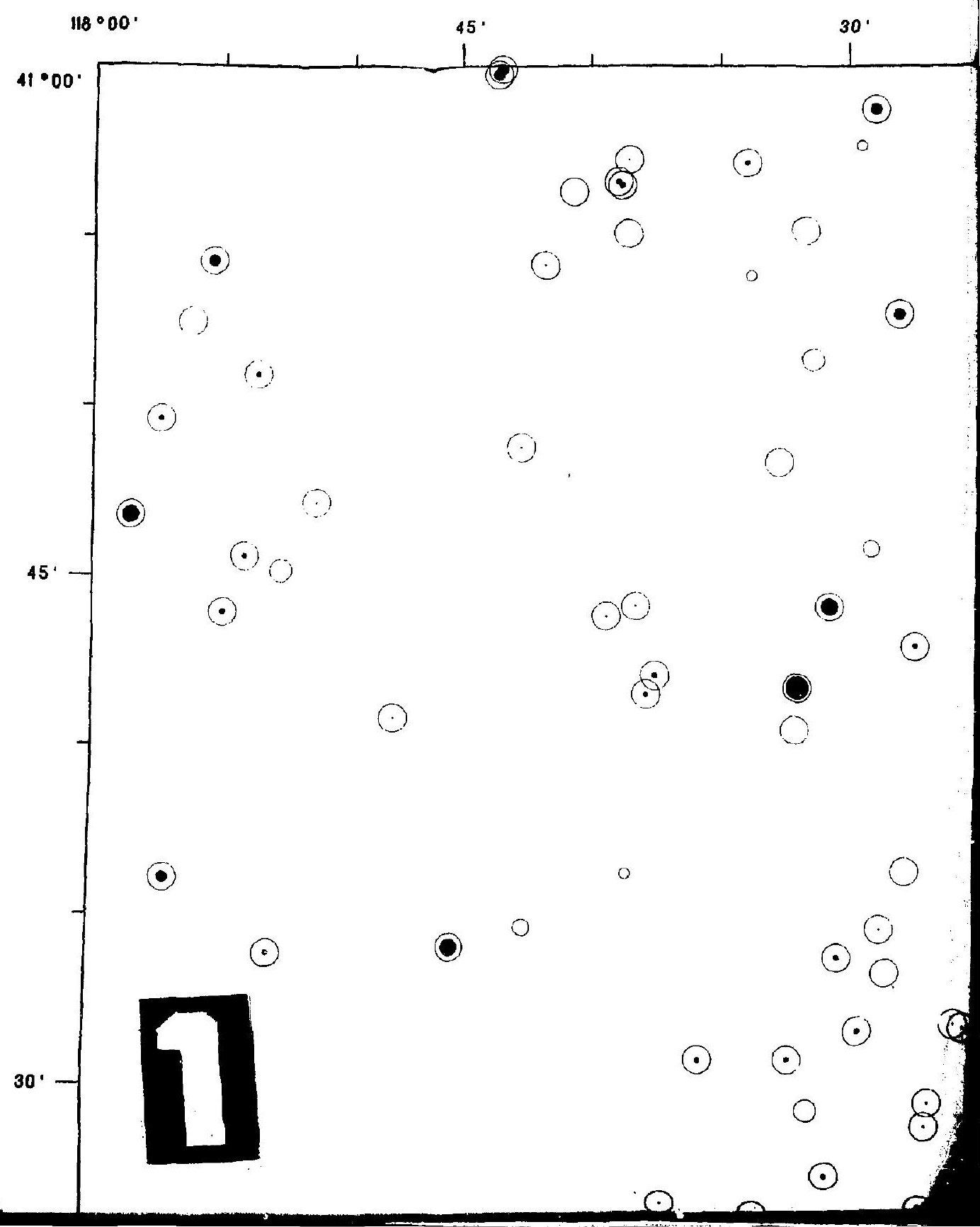




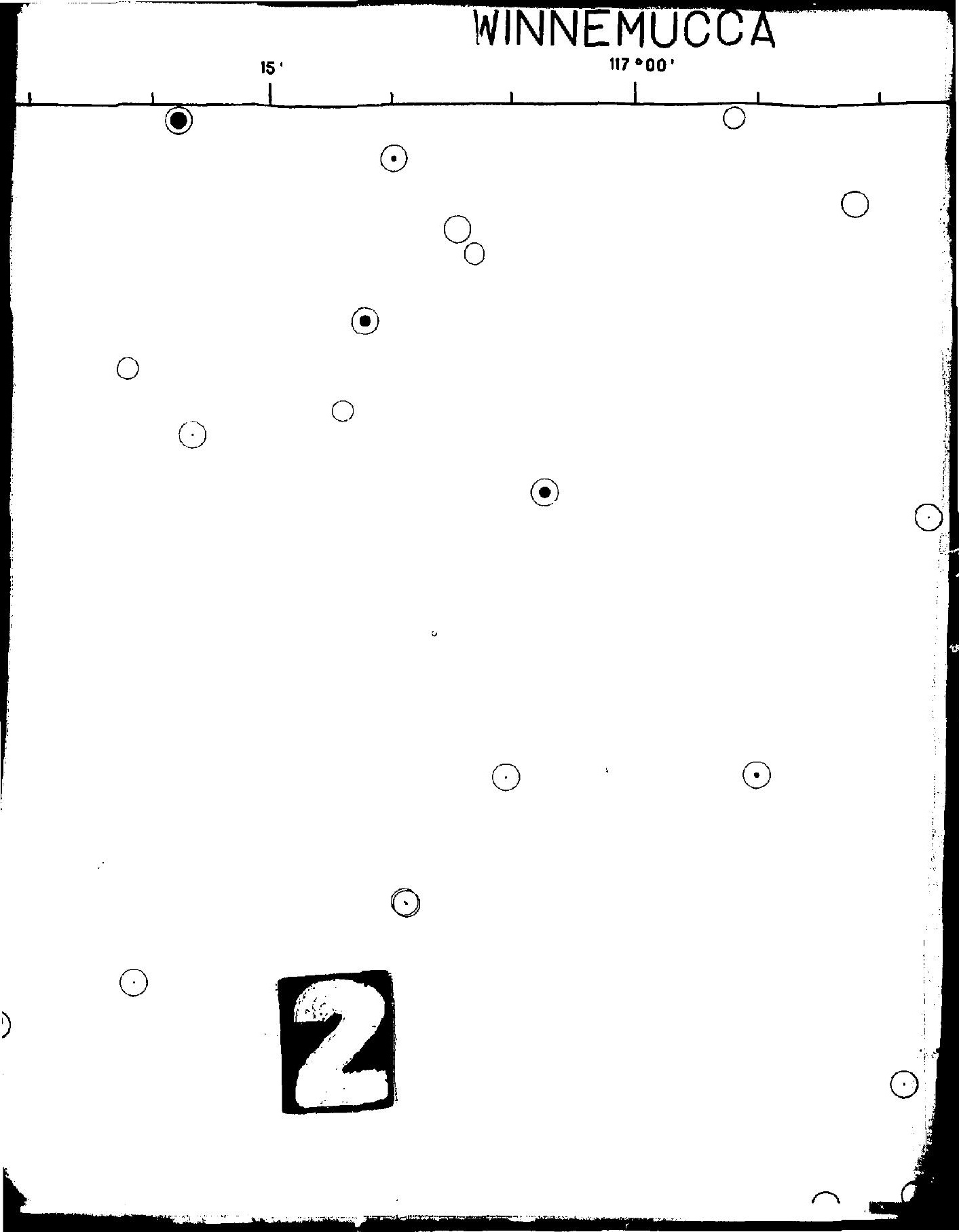




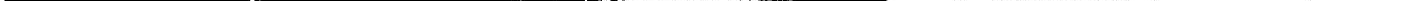




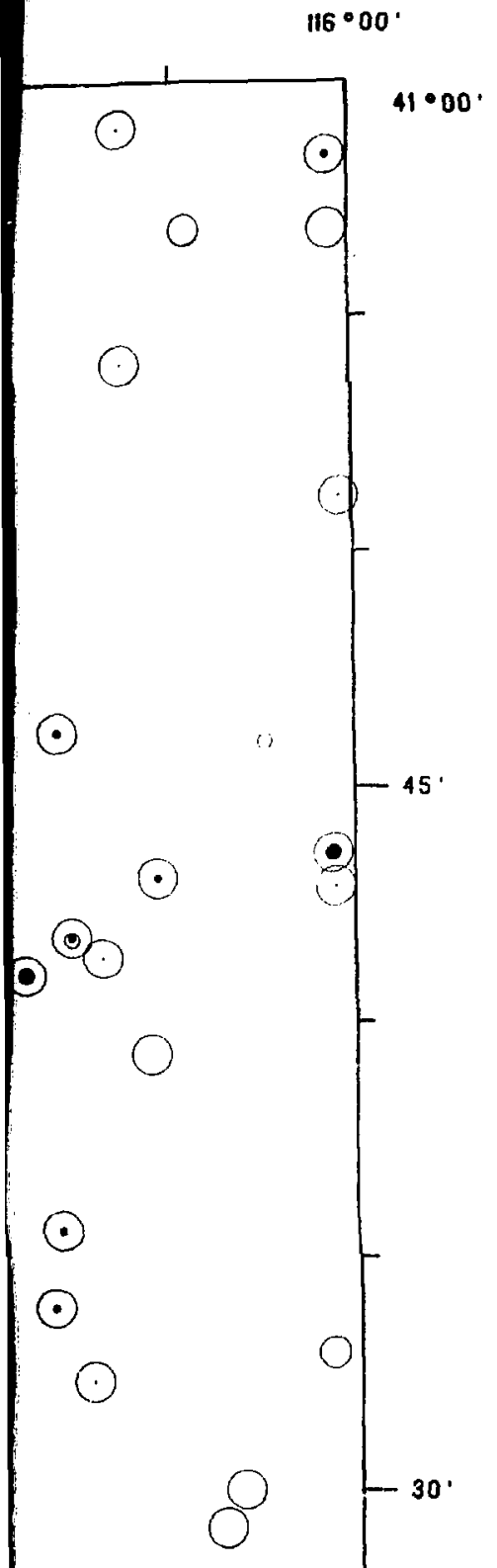




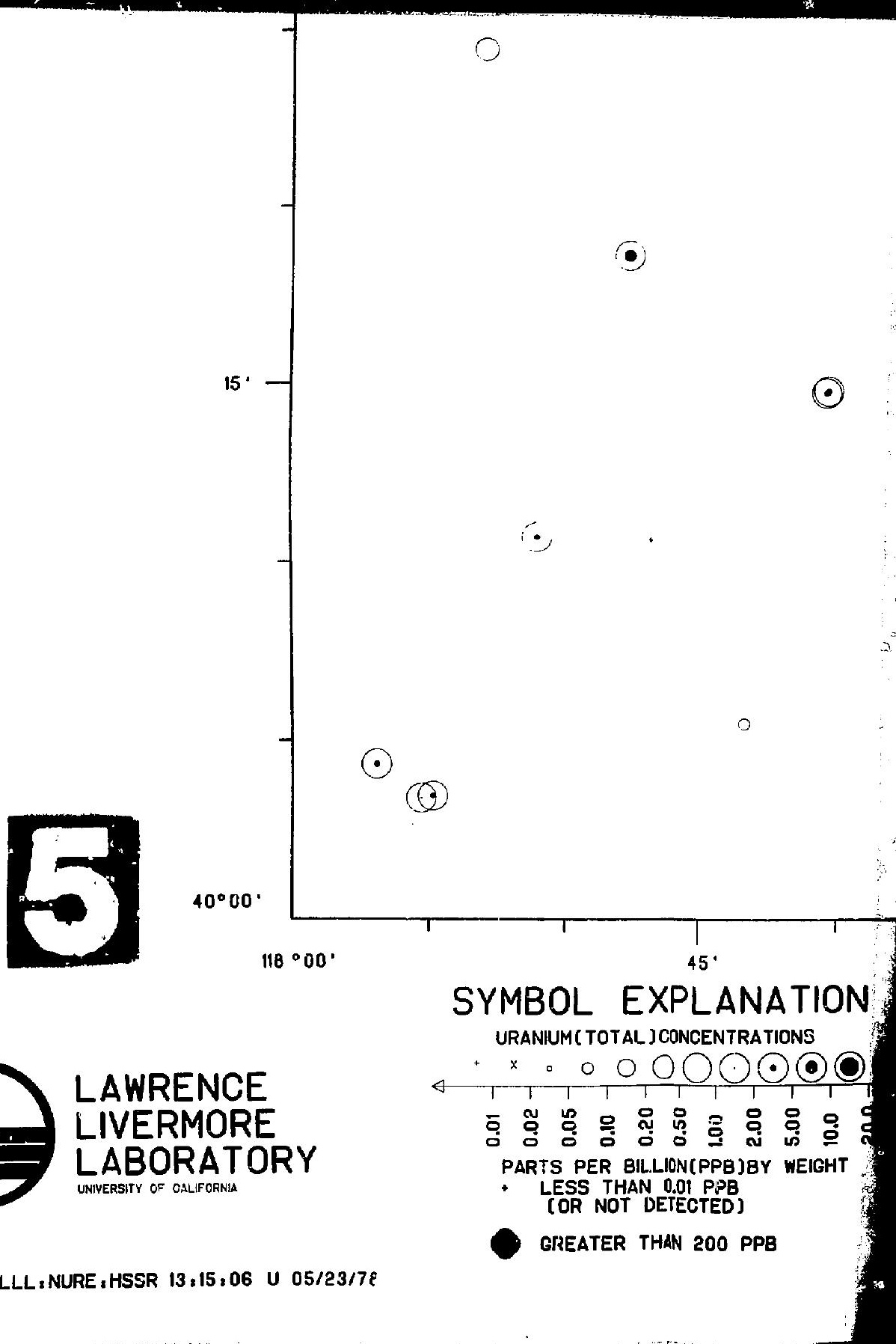




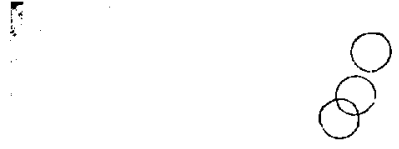

0

(D)

$\odot$

$\odot$

0

$\odot$

0
○

()

(8)

$\odot$

(1)

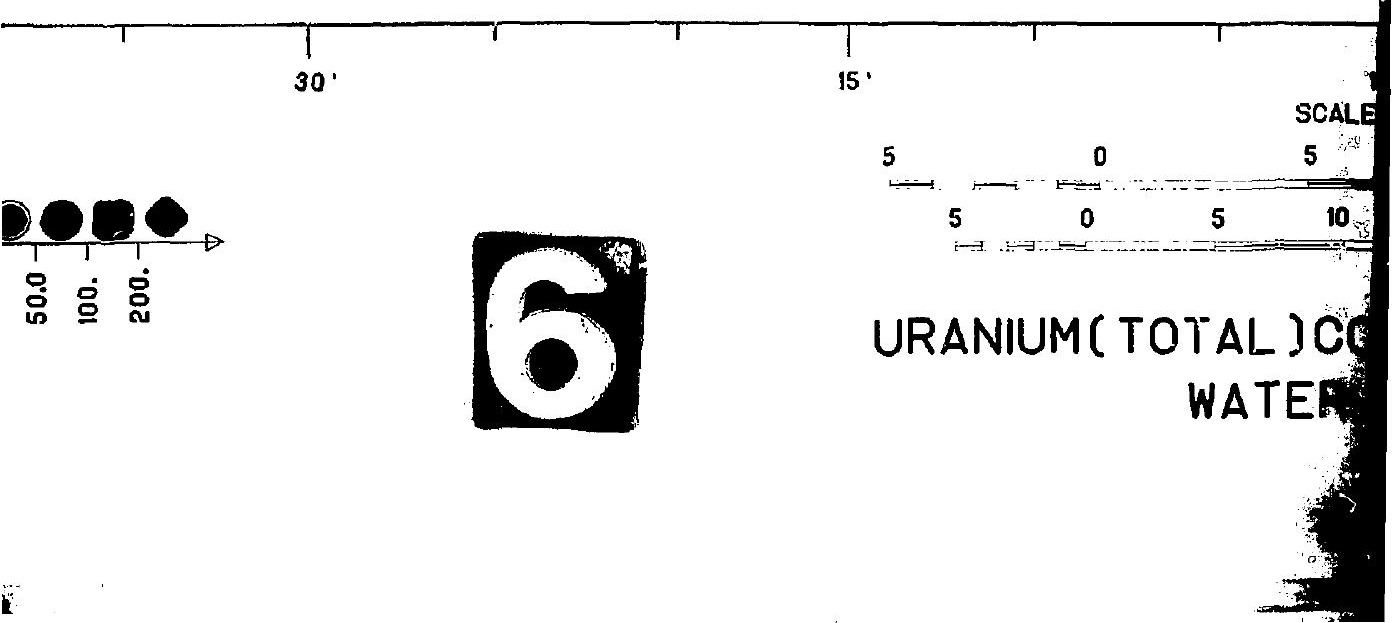

0

๑) 
$\odot$

$\odot$

$\odot \odot \odot$

$\odot \odot$ 
$\odot \odot$

$\odot$

○

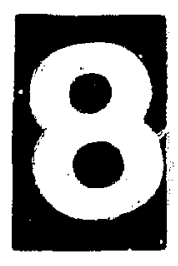

GEOCHEMICAL RECONNAISSANCE STUDY 


\section{WINNEMUCCA}

15 .

$117^{\circ} 00^{\circ}$

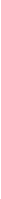

$\therefore 7031$

0,559585596

$\begin{array}{ll}07076 & 07079 \\ 07078\end{array}$
$077 \mathrm{a}$

G. 7644

07023

$\begin{array}{lc}07018 & 07023 \\ 7017 \text { o } & 07024^{7006} \\ & 07025\end{array}$

$\square 7704$

$$
07710
$$

$$
\begin{array}{cc}
05599 & 0_{7077} \\
0_{7523} \mathrm{~L} & 0_{5600}
\end{array}
$$

\section{3}

$06442^{06443}$

6437
06436
$0780 \div$

$$
4.721
$$$$
7702 \text { o } 07701
$$$$
\begin{gathered}
0.813 \quad 07703 \\
07812 \quad 07805 \\
07819
\end{gathered}
$$$$
07806
$$$$
\varphi_{7615}
$$$$
07810
$$

$$
07807
$$$$
19753 \delta_{0792}^{19751}
$$$$
31910
$$

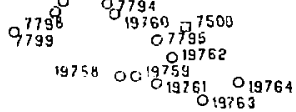

07719

07747

07246

$$
07245
$$

$72490,5 \leq 55$

$$
\begin{gathered}
07247 \\
\text { F954 } 0^{72+8}
\end{gathered}
$$

87243

$$
0^{19765}
$$

Orops

$$
\begin{aligned}
& 0^{6441} \\
& 0^{6440} \\
& 0_{643}
\end{aligned}
$$

26439

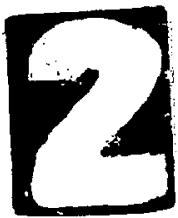

$$
\begin{aligned}
& \begin{array}{c}
07242 \quad 07250 \\
06380
\end{array} \\
& O_{6379} \\
& 74990 \quad 019760^{06340}
\end{aligned}
$$$$
17 .: 5
$$

06392

374

37743

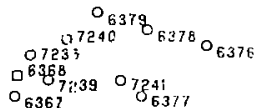

$\therefore \ddot{2}=5$

013754

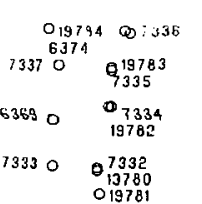

$$
0^{19755}
$$

019769

$$
07237
$$

7905007236

$$
636307231
$$

7234 O5655

0636407232

$$
06381 \quad 0^{7329}
$$

733106370019779

$$
19777 \text { 通 } 162
$$

$$
63710_{7330} 0_{6387}
$$

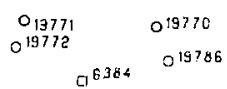

$\mathrm{O}_{19773}$

$63586_{6357}$
16953

$10 \$ 6362$

P $\quad 7228$
O 706

(1) 


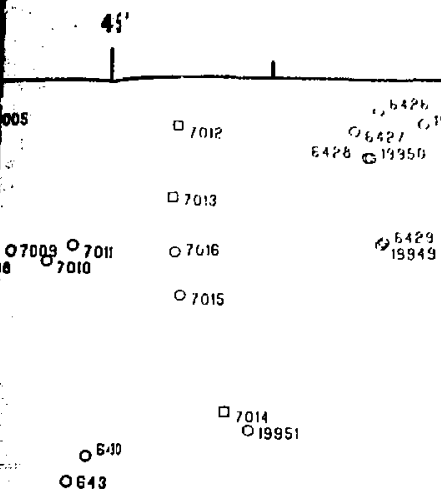$$
\text { - b49k }
$$

0 ำ? G1955

C. 7013

$07088_{7010}^{\circ}$

$0^{640}$

0643

$$
\begin{aligned}
& 07016 \\
& 07015
\end{aligned}
$$

5429
19349

06432

$0_{6435}$

$340^{\circ} 6433$

$0_{645}$

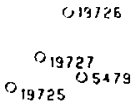

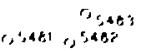

rigite

(2), 400 


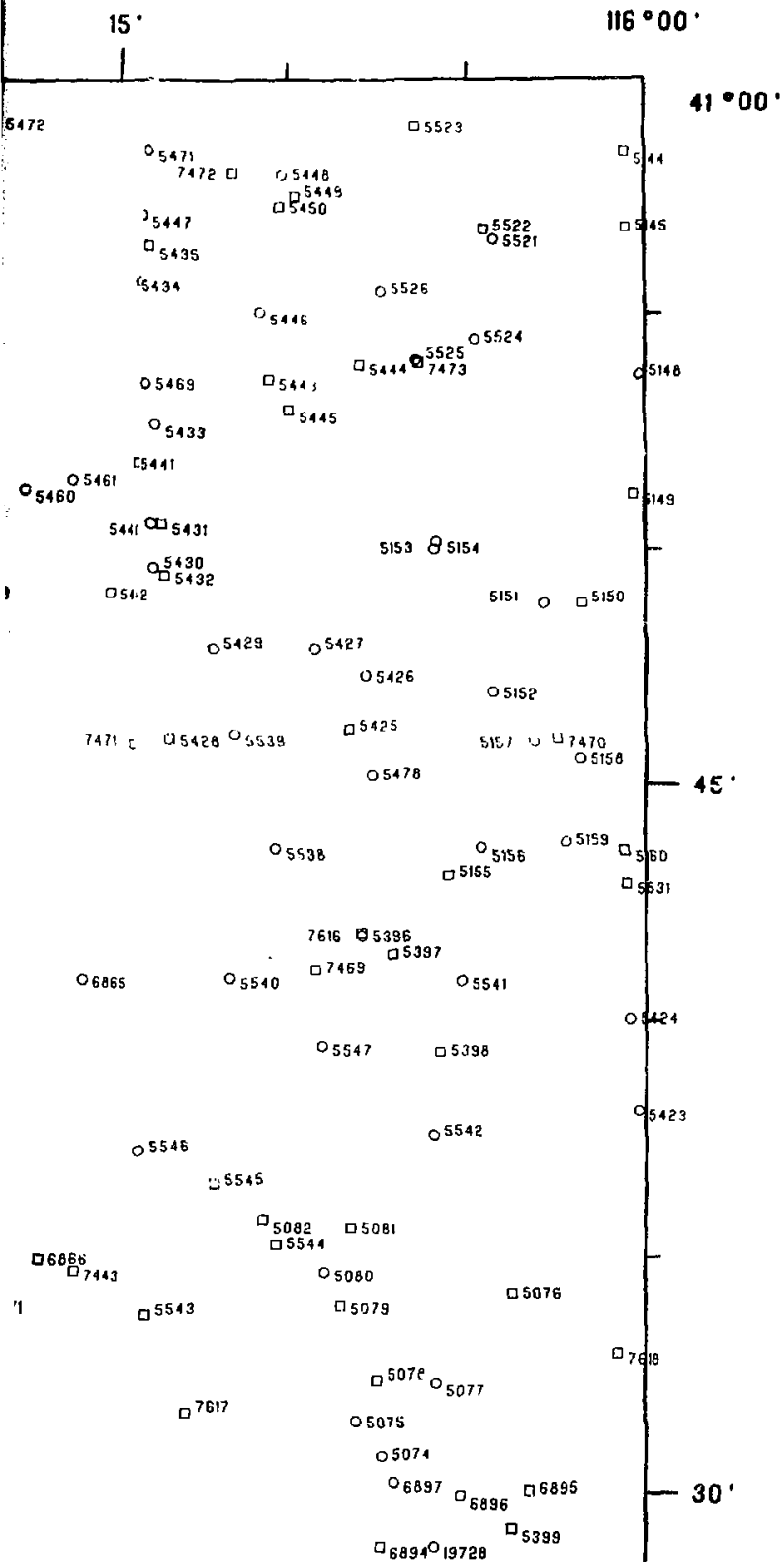




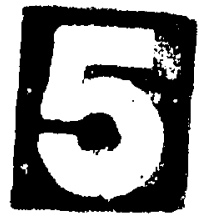

$40^{\circ} 00^{\circ}$

$118^{\circ} .00^{\circ}$
[] $12,5,1$

(j):205

1,106

, ?p?

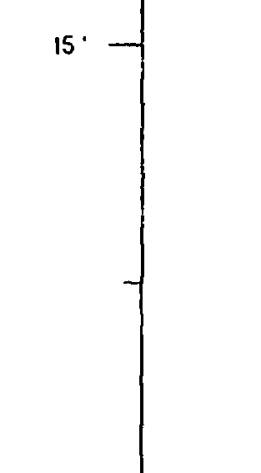

prots

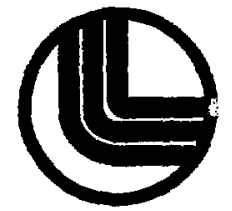

LAWRENCE

LIVERMORE

LABORATORY

UNIVEASITY OF CALIFORNIA

Lita

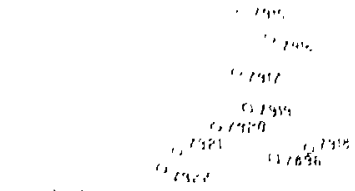

.201

$\therefore i n$

s, 1.16

N132

(1), 35

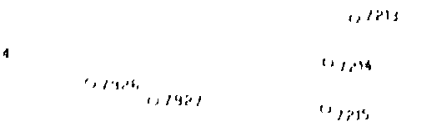

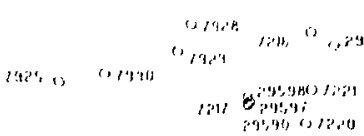

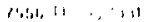

$1,14 ! 17 \quad 1.17+4$

a1 11

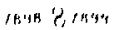

()) $M$ 1

in tritin

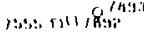

(, $1: ., 1)$

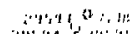

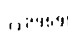

II

t)

אונים

(i)

,

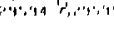

$n+\cdots+11$
$\therefore \cdots !$

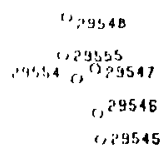

(s pot

.

() 7306 
06764 06946

$13230013 \% 1$

0.76945
$06765 \quad 07170$
06943
07171

$13 \%+1,10,9$

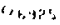

$" 1, y$,

$$
\begin{gathered}
0,6943 \\
0>171
\end{gathered}
$$

$1294116037^{\circ}+33^{21}$

1, f. $4 \%$

Constis

$0 \sin 2$

$\square 7157$

Q $)>0.21$

$0_{\left(30^{\prime}\right)} 0_{6941} 0_{6941]}$

B768

व7158

7159 160

(3) 6761

o 07310

(i) 13190

6922

a. $1: 14 !$

(1) 634

136341

1318 of 13 is

07312

06921

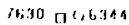

06343

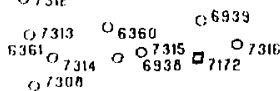

1631 0 O6340 (163t1

Q 6351

63212

36242

07113

07745

(1) $1: 341$

29563 0029564

$$
\text { 11.24566 00565 }
$$

07174

Q) 11,15

OP9662 OPG5F

II:21 H:Ti:

\section{$117: 3$ \\ is, 1,4}

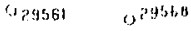

I/19

c.)6315

(1) (istiph

(1):10.60 0205609

(1) 24511

(3) $3 \log 4$

():?!:!,

(c) 201,11

6.34t; I1 11:512

$$
\text { (1) Givis (,b317 }
$$

ofing

07520

lastll 06319

i] / 510

Q6321

Oparto

Untt;

costot ops?

1) 5337

, b.334

(1) 6516

Opasofi

(1)

549

$$
\begin{aligned}
& \text { c) istson } \\
& 0,295 / 6
\end{aligned}
$$

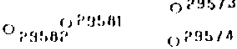

11] [515 $11 / 121$

11, In:

a1900

(5)2953

o.29s

9586 它识多:

29576 "0?56/5

$$
0^{1760^{12 H}}
$$

i) 11.

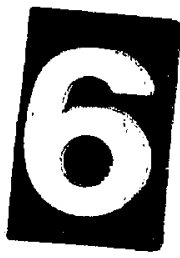

5

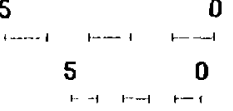

SITE LOCATIONS,

0

5

10 
a6gtidts

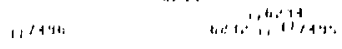

, $4646_{2}$

itht:

$$
1,11
$$

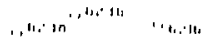

$11,11 H_{11: 11:}$

$$
11,0,1+04,1+1,0,1
$$

11:12,

lin.1 $1,, 1,1,14$

I Inat:

แนกเเ

$$
\text { "H, तn }
$$$$
\text { Chisits }
$$

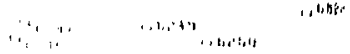

$$
\begin{aligned}
& 11,1,14
\end{aligned}
$$

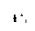$$
\text { 1, barde }
$$$$
\text { "ton" }
$$$$
\text { , whin }
$$$$
\text { ., 130 14 }
$$

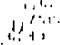$$
\text { I...... }
$$$$
\cdots,+1
$$

$$
\text { inn } 10
$$

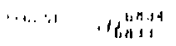

' ' $h, 1+1$

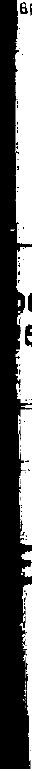

1,163
, tnnt

$11+11$ atrin It

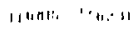

at tinte

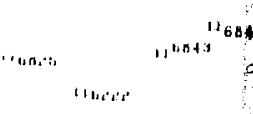

| $/ / t_{1} t^{2} \mid$ 


$$
\begin{aligned}
& 19350 \quad 0 \quad 031306893019735 \\
& \begin{array}{lll}
\text { 6312 0.19955 DE311 } & 0^{19734} \\
& 019735
\end{array}
\end{aligned}
$$

$7624^{\circ} 6223$

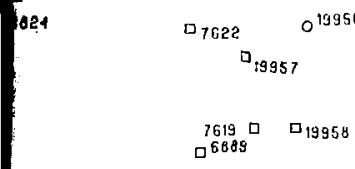

$0689^{\circ}$

Otgi2

0 6211

O6214

$0^{6213}$

08210

305

O6881 $68830 \quad 06884$

c.6885

06666

, 6801

06802

62996882
$0^{19736}$

$06309 \quad 019737$

$\square^{6091}$

07405

0.03310

$06306 \%$

019959

$r_{3} 304$

01996

$15^{\circ}$

06804

$0_{6803}$

$0 / 483$

$0_{6303} 0_{6301}$

06300

06298

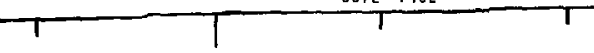

15

$116^{\circ} 00^{\circ}$

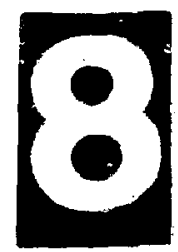

OVERLAY 2A

SITE LOCATIONS. SEDIMENT SAMPLES

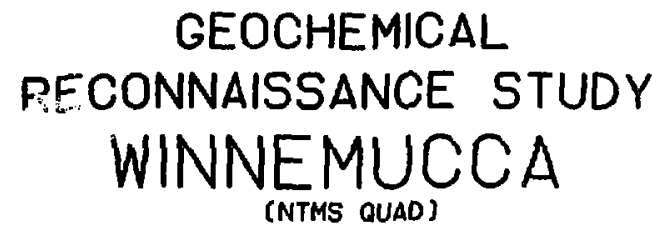




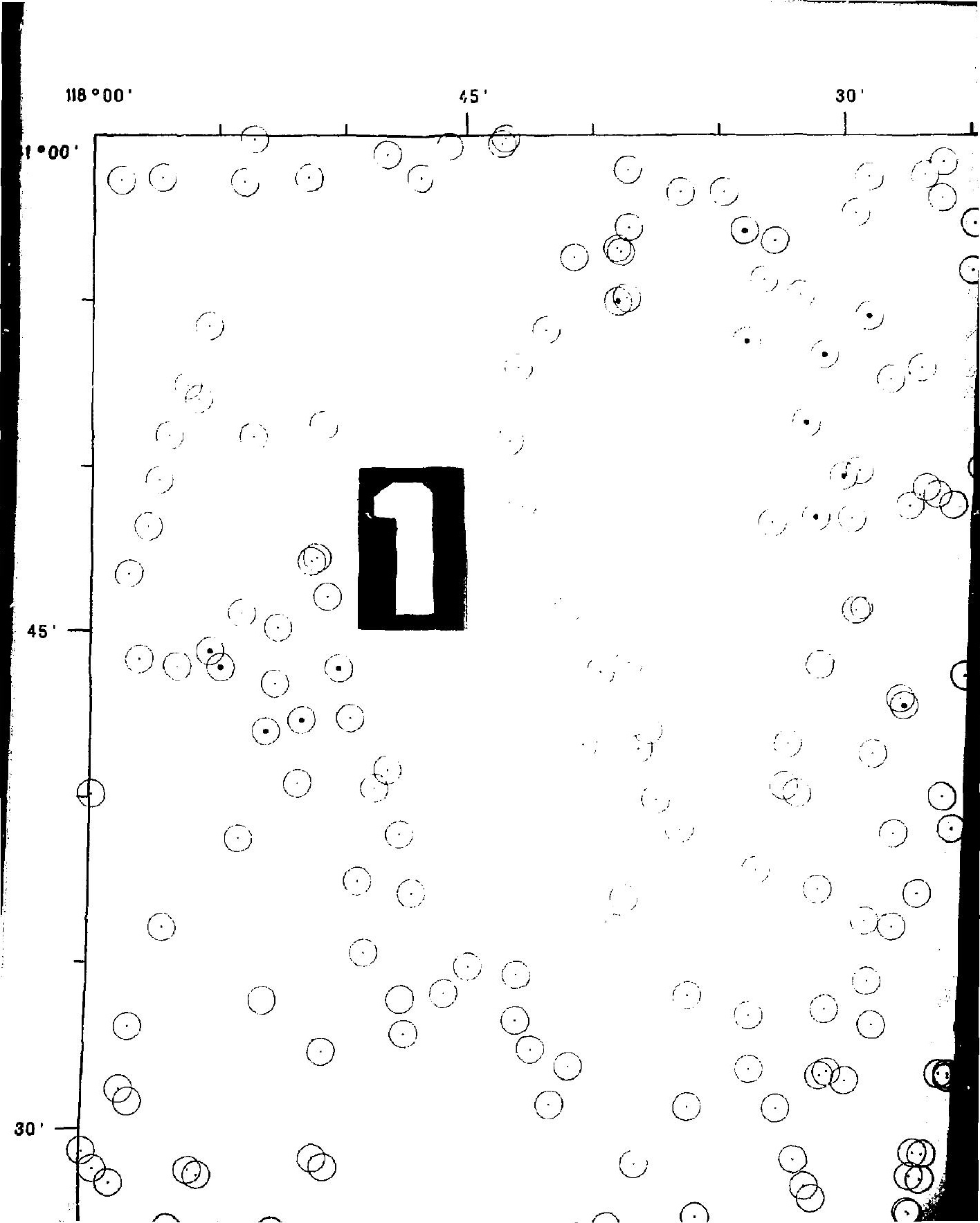


$6^{\circ}$

$\odot^{\circ}$

$\odot \quad g$

0

$0^{\circ} \bigcirc$

$\odot$

$\odot \odot_{\odot}$

$\odot \odot$

$\odot$

○

(.)

( )

( )

9

(2)

$\theta 0$

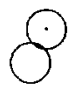

$\odot$<smiles>c1ccccc1</smiles>

$\theta 000$

o

$\theta^{\circ} \odot \odot^{\circ} \odot$

$\odot^{\circ}$

$\odot$

(C)

( 0

$\theta 0$

( )

0

$\theta$

(i)

( )

(.) (5)

( )

( )

(2)

(.)

$0 \dot{0} 0$

00

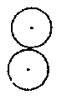

(i)

(D)

(2)

( )

(i)

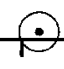

$45^{\circ}$

$117^{\circ} 00^{\prime}$

LLE 1,250000

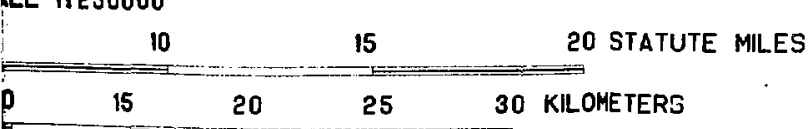

10

M]

SAMPLES

4 


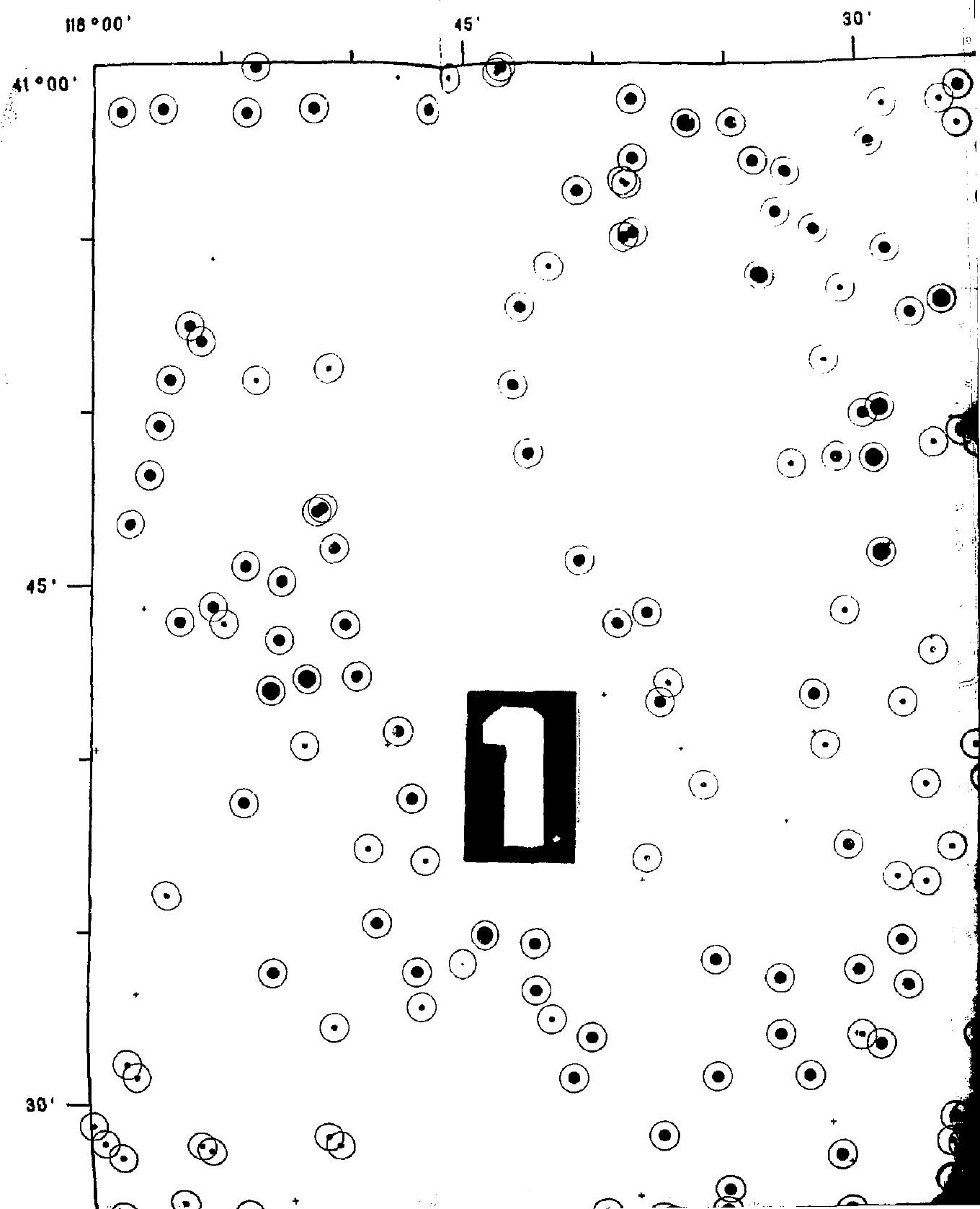


WINNEMUCCA

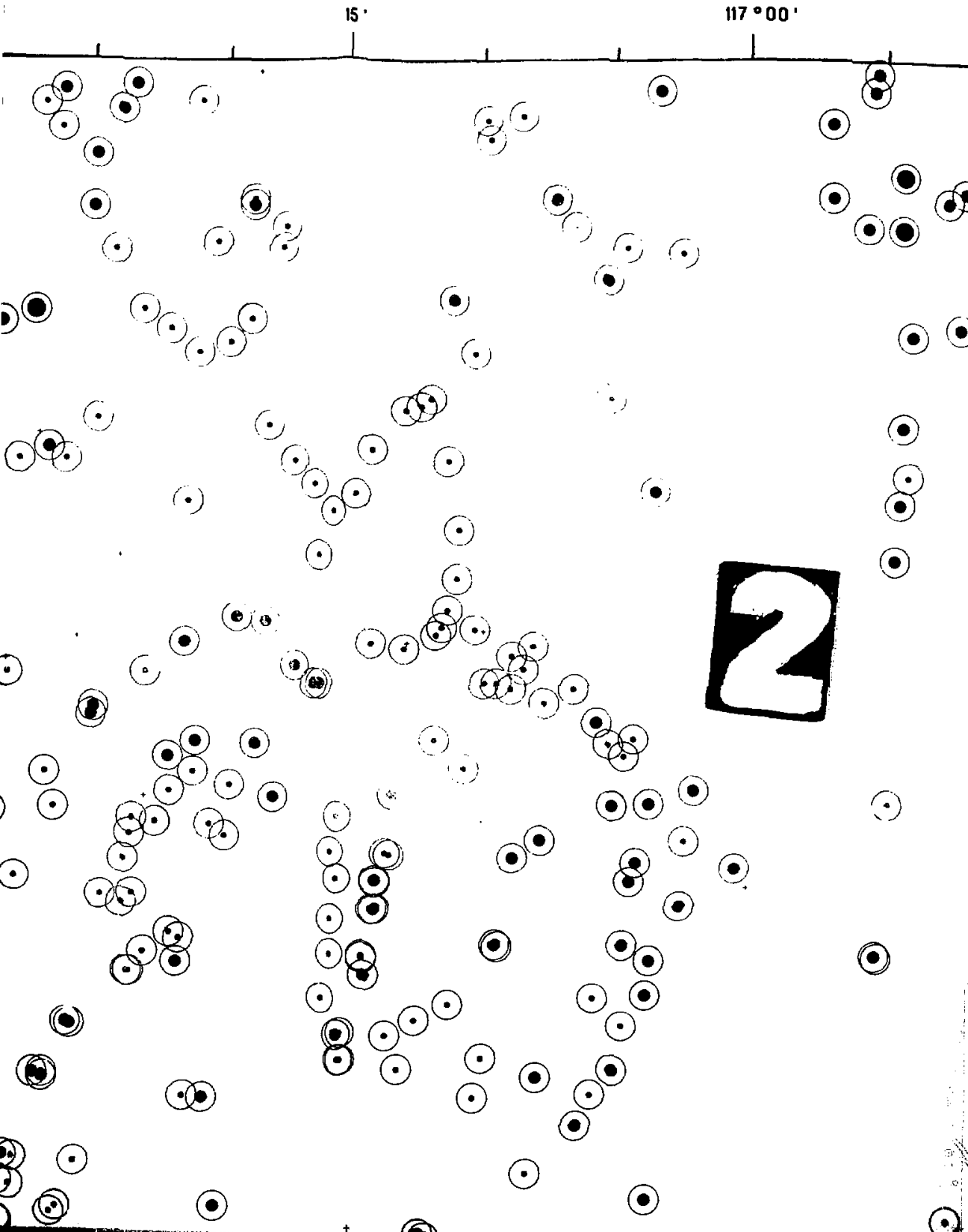




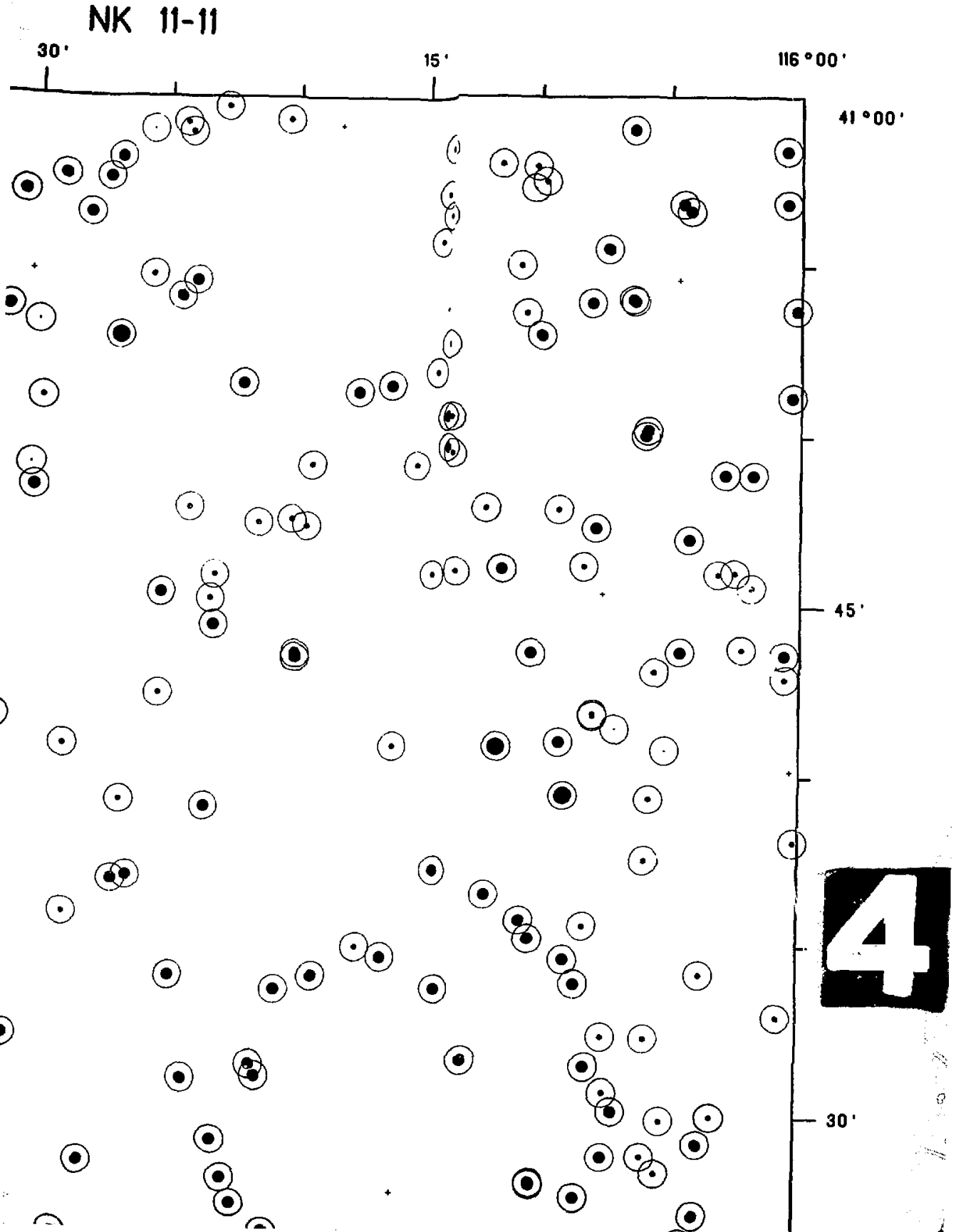



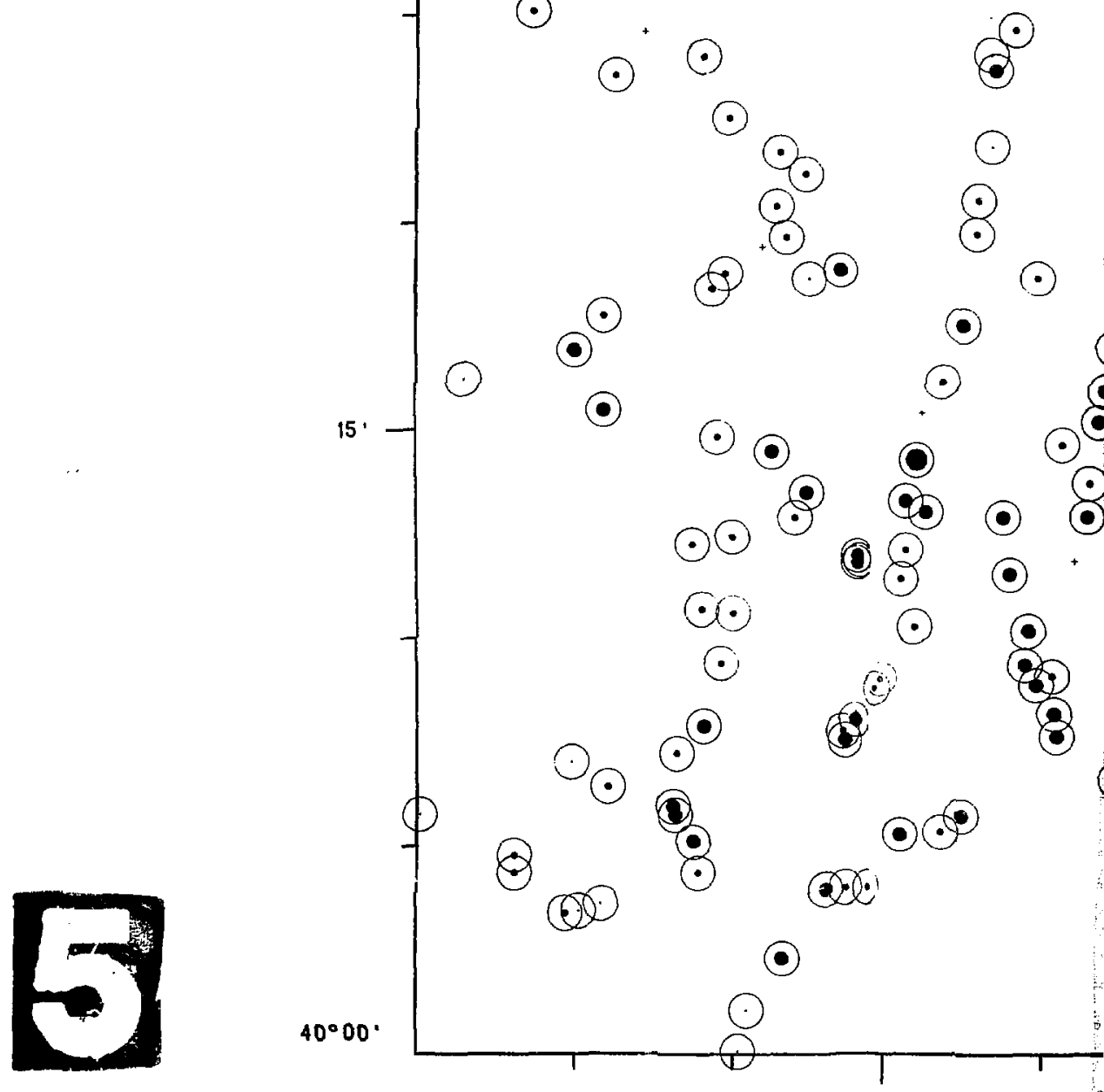

$118^{\circ} 00^{\circ}$

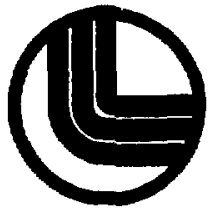

LAWRENCE LIVERMORE LABORATORY UNIVERSITY OF CALIFORNIA

$45^{\circ}$

SYMBOL EXPLANATION

THORIUMI(TCTAL) CONGENTRATIONS

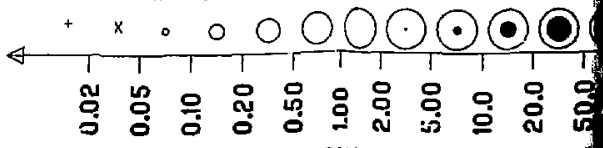
PARTS PER MILLIONIPF'M]BY WEIGHT + LESS THAN 0.02 PPM [OR NOT DETECTED] GREATER THAN 500 PPM 
$\theta$

$\infty$

$\odot$

$\odot$

(2)

600

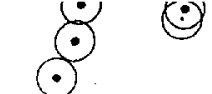

$\bullet$

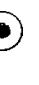

$\odot$

$\bullet$

60 8908<smiles>C=C(C)S(=O)(=O)O</smiles>

$\odot$

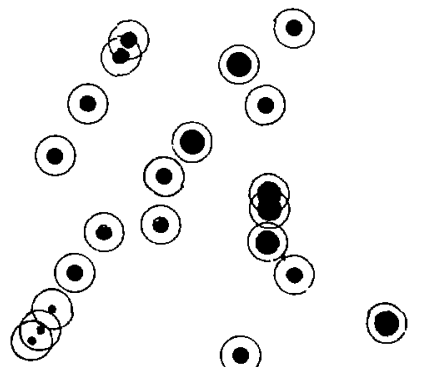

$\odot$

$\odot \circ$

8

$\odot \odot \odot$

$\odot$

$\odot$

$(2)$

-

$\bullet$

(-)

$\odot$

$\circ$

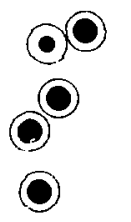

$\odot$

() $\odot$

$\bullet$

(6)

(c)

$\odot$

$\odot$
0

영 $\infty$

(a)

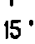

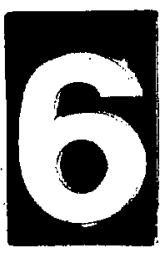

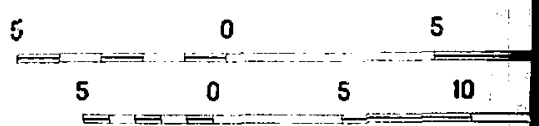

THORIUM( TOTAL) CON SEDIMENT 


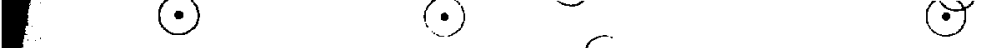

$\odot$

$\odot$

$\odot \odot$

$\odot \quad \bullet$

8

$\bullet$
$\odot \odot \odot$

$\odot \odot$

(•)

$\odot \odot \odot$

$\theta$

$\odot$

$\odot$

$\odot$

$\bullet$

$\odot \odot$

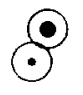

$\bullet$

${ }^{\circ} \varphi_{\odot} \odot$

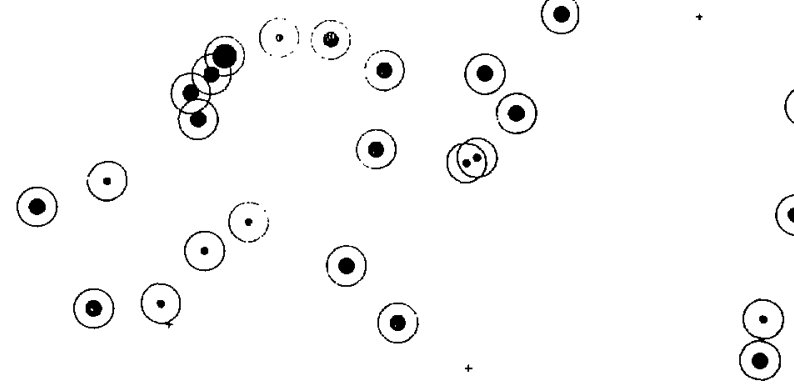

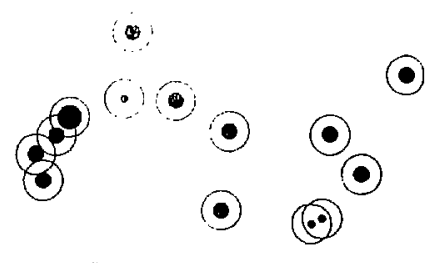

(

$\bullet$

$\bullet$

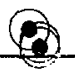

(c)

0

$\odot \odot$

$\odot$

$\bullet$

$\ominus$

$\bullet$

(

$\odot \odot$

$\odot$

$\odot$

$\sqrt[4]{1}$

$117^{\circ} 00^{\circ}$

E 1.250000 15 20 STATUte MILES 15 20 25 30 KILOMETERS

ONCENTRATIONS (PPM)

$T$ SAMPLES 
$00 \%$

$(6)$

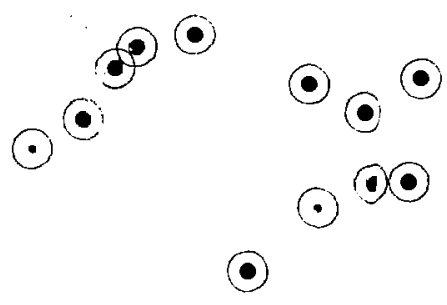

$\bullet$

8

$\odot \odot$

(อ)

$\bullet \odot$

$\odot \bullet$

$\odot$

(อ)

$\odot$

$\bullet$

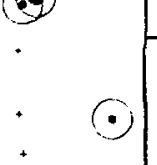

-

$\odot \odot$

$\odot$

$\odot$

$\odot$

(a)

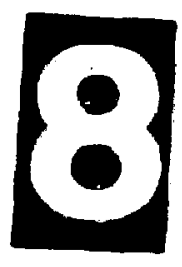

$40^{\circ} 00^{\prime}$

$\bullet$

15 $\odot$

$\bullet$

$\odot$

(

6

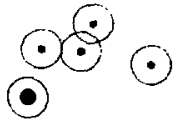

(-)

()

15

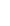

